Prepared in cooperation with the County of Lycoming

\title{
Groundwater Quality for 75 Domestic Wells in Lycoming County, Pennsylvania, 2014
}

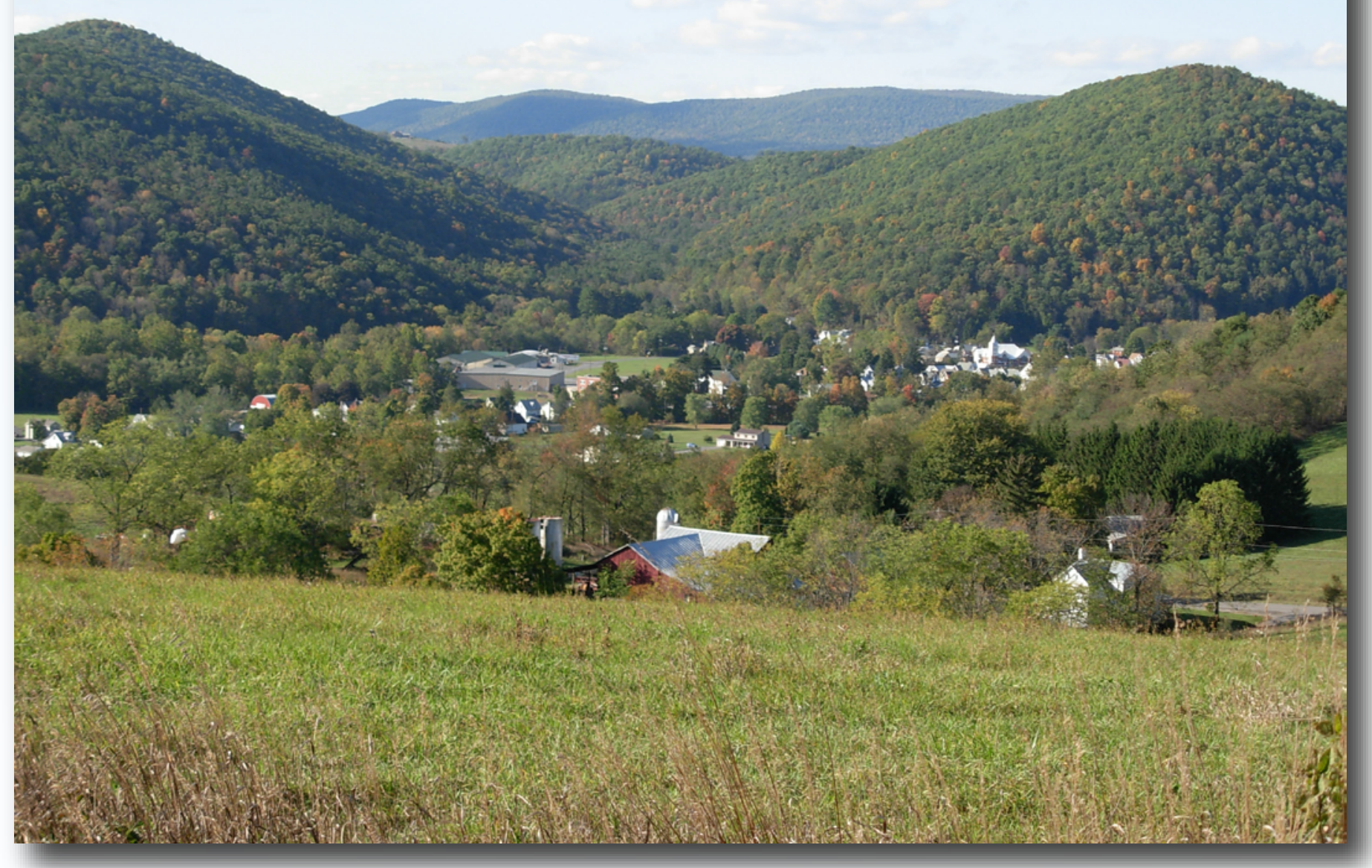

Scientific Investigations Report 2016-5143 
Cover: Example of common topographic features in the Ridge and Valley Physiographic Province of Lycoming County, Pennsylvania. (Photograph provided by Lycoming County Planning and Community Development Department) 


\section{Groundwater Quality for 75 Domestic Wells in Lycoming County, Pennsylvania, 2014}

By Eliza L. Gross and Charles A. Cravotta III

Prepared in cooperation with the County of Lycoming

Scientific Investigations Report 2016-5143 


\section{U.S. Department of the Interior SALLY JEWELL, Secretary}

\section{U.S. Geological Survey Suzette M. Kimball, Director}

\section{U.S. Geological Survey, Reston, Virginia: 2017}

For more information on the USGS - the Federal source for science about the Earth, its natural and living resources, natural hazards, and the environment—visit http://www.usgs.gov or call 1-888-ASK-USGS.

For an overview of USGS information products, including maps, imagery, and publications, visit http://store.usgs.gov.

Any use of trade, firm, or product names is for descriptive purposes only and does not imply endorsement by the U.S. Government.

Although this information product, for the most part, is in the public domain, it also may contain copyrighted materials as noted in the text. Permission to reproduce copyrighted items must be secured from the copyright owner.

Suggested citation:

Gross, E.L., and Cravotta, C.A., III, 2017, Groundwater quality for 75 domestic wells in Lycoming County, Pennsylvania, 2014: U.S. Geological Survey Scientific Investigations Report 2016-5143, 74 p., https://doi. org/10.3133/sir20165143.

ISSN 2328-0328 (online) 


\section{Acknowledgments}

This project was financed [in part] by a grant from the Commonwealth of Pennsylvania, Commonwealth Financing Authority. This project was completed in cooperation with the County of Lycoming and with contributions from the West Branch Regional Authority, North Central Source Water Protection Alliance, and Pennsylvania Department of Environmental Protection.

Assistance and support from those residents of Lycoming County who made their wells accessible for sampling is greatly appreciated as this work would not have been possible without their participation.

Water samples were collected by Dominick Antolino, Karen Beaulieu, Lee Eicholtz, Eliza Gross, Dana Heston, Brad Huffman, Jacob Kolke, Dennis Low, and Brian Selck of the U.S. Geological Survey. 



\section{Contents}



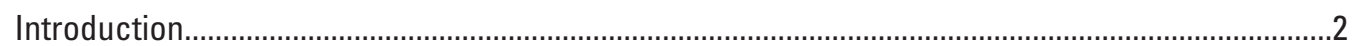

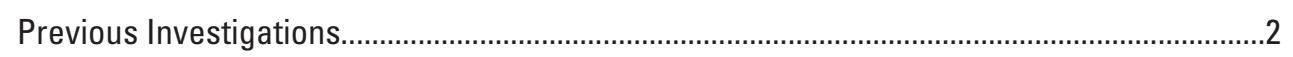

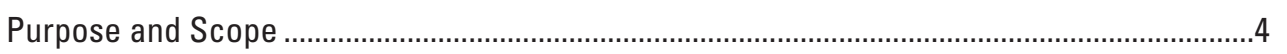



Population, Water Supply, and Land Use....................................................................

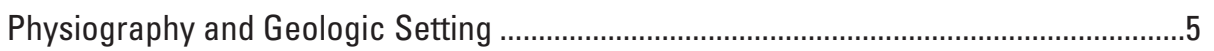



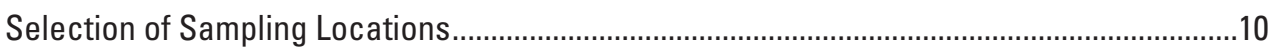



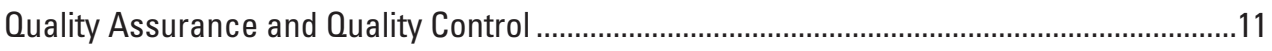







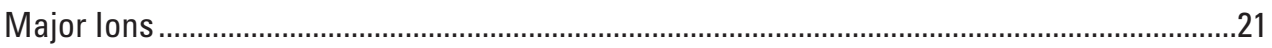

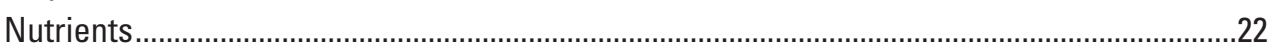

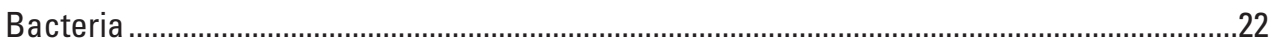



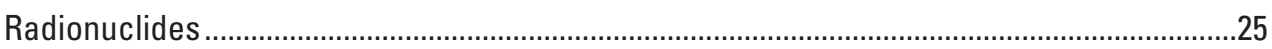

Dissolved Methane and Other Naturally Occurring Hydrocarbon Gases..............................28

Manmade Organic Compounds........................................................................................28



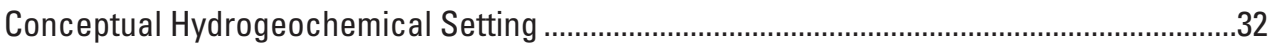

Correlations Among Major and Trace Constituents in Groundwater.....................................34

Relations Among pH, Specific Conductance, and Constituent Concentrations ..............34

Ionic Contributions to Conductivity and Total Dissolved Solids.......................................36

Principal Components Analysis of Interrelations Among Constituents...........................38

Relation Between Groundwater Quality, Geology, and Topographic Setting ..........................40

Major Ion Compositions Indic ated by Piper Diagrams....................................................41

Water-Quality Variations and Water-Rock Interactions .................................................41

Chloride, Bromide, and Sodium in Groundwater ..............................................................

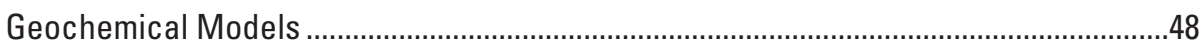

Isotopic Composition of Methane and Origin of Methane Gas......................................48

Spatial Distribution of Dissolved Methane and Associated Constituents ......................52



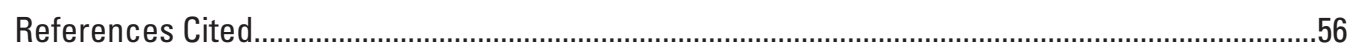

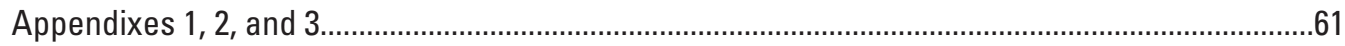

Appendix 1. Compilation of data not available in the National Water Information System (doi http://dx.doi.org/10.5066/F7P55KJN), including station name, station identification number, lithologic class, and topographic position index, for wells sampled by the U.S. Geological Survey in Lycoming County, Pennsylvania, June-August 2014. (Appendix 1 available online as Excel file at https://doi.org/10.3133/sir20165143) 
Appendix 2. Spearman rank correlation coefficient $(r)$ matrix for groundwater chemical data Lycoming County, Pennsylvania, 2014. (Appendix 2 available online as Excel file at https://doi.org/10.3133/sir20165143)

Appendix 3. Distributions of continuous variables were compared among different sample classifications using notched boxplots (Velleman and Hoaglin, 1981; Helsel and Hirsch, 2002). Statistically significant correlation coefficients and boxplots are presented. Where the median for a group is greater than the common reporting limit, it is displayed as a horizontal line within the box that is defined by the $25^{\text {th }}$ and $75^{\text {th }}$ percentiles for that group; otherwise, the median is displayed at the reporting limit. If the notched intervals around the medians for sample subsets do not overlap, the medians are statistically different at the 95-percent confidence interval

\section{Figures}

1. Map showing land use, State-owned lands, conventional and unconventional active oil and gas well locations drilled as of June 2016, and water supply in Lycoming County, Pennsylvania

2. Map showing geologic units (most near surface bedrock) and glaciated area in Lycoming County, Pennsylvania

3. Map showing spatial distribution of 75 domestic water wells sampled and lithologic classes in Lycoming County, Pennsylvania

4. Graphs showing comparison of field, laboratory, and (or) computed values of specific conductance (SC), total dissolved solids (TDS), or alkalinity for 75 groundwater samples from Lycoming County, Pennsylvania, 2014. A, field- and laboratory-measured SC; $B$, measured TDS as residue on evaporation (ROE) at 180 degrees Celsius by two different laboratories; $C$, alkalinity measured by incremental titration in the field and the computed value, estimated to achieve ionic charge balance; $D$, measured TDS (as ROE) and calculated TDS as the sum of dissolved constituent concentrations, including the estimated alkalinity; $E$, field- or laboratory-measured SC and calculated SC on the basis of ionic conductivities; and $F$, field- or laboratory-measured SC and calculated TDS on the basis of dissolved constituent concentrations

5. Map showing lithologic classes and spatial distribution of $\mathrm{pH}$ concentrations in groundwater samples collected from 75 wells in Lycoming County, Pennsylvania........20

6. Map showing spatial distribution of chloride concentrations in groundwater samples collected from 75 wells and land use in Lycoming County, Pennsylvania ........23

7. Map showing spatial distribution of arsenic concentrations in groundwater samples collected from 75 wells and lithologic classes in Lycoming County, Pennsylvania .

8. Graph showing relation between $\mathrm{pH}$ and arsenic concentration in groundwater samples collected from 75 wells in Lycoming County, Pennsylvania... 
9. Graph showing relation between $\mathrm{pH}$ and boron, bromide, and lithium concentrations in groundwater samples collected from 75 wells in Lycoming County, Pennsylvania .

10. Graph showing relation between $\mathrm{pH}$ and fluoride and sodium concentrations in groundwater samples collected from 75 wells in Lycoming County, Pennsylvania........27

11. Graph showing relation between $\mathrm{pH}$ and dissolved methane concentration in groundwater samples collected from 75 wells in Lycoming County, Pennsylvania........29

12. Graph showing schematic diagram of generalized conceptual hydrogeochemical setting for fresh and saline groundwater in a fractured bedrock aquifer setting

13. Graphs showing concentrations of selected constituents in groundwater samples collected from 75 wells in Lycoming County, Pennsylvania, 2014, compared to $A-C$, $\mathrm{pH}$; or $D-F$, specific conductance

14. Graphs showing major ion contributions to specific conductance (SC) for groundwater samples collected from 75 wells in Lycoming County, Pennsylvania, 2014. $A$, comparison of estimated ionic conductivity contributions by sodium, calcium, magnesium, chloride, bicarbonate, and sulfate to measured SC; and $B$, relative contributions by major ion species computed SC, expressed in percent, in order of increasing SC

15. Pie diagram showing ionic contributions to specific conductance (SC) computed for selected groundwater samples from Lycoming County, Pennsylvania, 2014 for wells, $A$, LY718, $B$, LY557, C, LY732, D, LY699, E, LY760; and F, LY722

16. Graphs showing trilinear diagrams showing $A$, predominant water types or hydrochemical facies; and $B$, data for groundwater samples collected from 75 wells in Lycoming County, Pennsylvania, 2014, plus median composition of brine from oil and gas wells in western Pennsylvania and flowback water from Marcellus Shale gas wells.

17. Graphs showing trilinear diagrams showing $A$, data for 17 selected groundwater samples from Lycoming County, Pennsylvania, 2014; and $B$, evolution pathways for mixing of dilute calcium/bicarbonate groundwater with road-deicing salt, with brine, with brine combined with cation-exchange, or with brine plus calcite dissolution to saturation and then cation-exchange.

18. Graphs showing saturation indices for minerals and other solids as a function of $\mathrm{pH}$ for groundwater samples collected from 75 wells in Lycoming County, Pennsylvania, 2014

19. Graphs showing equilibrium fractions of initial concentrations of $A$, anions or $B$, cations that may be dissolved or adsorbed on a finite amount of hydrous ferric oxide at 25 degrees Celsius as a function of $\mathrm{pH}$.

20. Graphs showing chloride concentrations compared to $A$, chloride/bromide mass ratios; $B$, bromide concentrations; $C$, sodium concentrations for groundwater from Lycoming County, Pennsylvania, 2014, plus median values for Salt Spring, flowback waters from Marcellus Shale gas wells, and oil and gas well brines from Western Pennsylvania ...

21. Graphs showing computed compositions of waters resulting from dissolution of road-deicing salt and (or) calcite, but without cation-exchange. Low-ionic strength groundwater (LY557) $A$, dissolves road-deicing salt without other reactions; $B$, dissolves road-deicing salt plus dissolves calcite to equilibrium; $C$, mixes with median oil and gas well brine without reactions; and $D$, mixes with median oil and gas well brine with calcite dissolution to equilibrium. 
22. Graphs showing computed composition of waters resulting from mixing of different solutions and (or) reactions including dissolution of calcite and cation-exchange. Low-ionic strength groundwater (LY557) dissolves incremental amounts of calcite until reaching equilibrium $A$, without cation-exchange; or $B$, with cation-exchange. Mixing of low-ionic strength groundwater with median oil and gas well brine (Dresel and Rose, 2010) $C$, with cation-exchange; and $D$, with calcite dissolution to equilibrium and cation-exchange

23. Graphs showing $A$, Isotopic composition of methane in groundwater samples collected from five wells in Lycoming County, Pennsylvania, 2014, and $B$, ratio of methane to higher-chain hydrocarbons in relation to carbon isotopic composition for methane in these samples

24. Boxplots showing the composition of groundwater samples collected from 75 wells in Lycoming County, Pennsylvania, 2014, classified by lithology, pH, and specific conductance.

25. Map showing spatial distribution of dissolved methane concentrations in 75 wells sampled and topographic position index categories in Lycoming County,

Pennsylvania

\section{Tables}

1. Geologic units grouped by lithologic class based on geologic unit characteristics, including name, map symbol, age, and primary lithology from Pennsylvania Bureau of Topographic and Geologic Survey (2001) and additional lithologic and water quality descriptions from Taylor and others (1983)

2. Available U.S. Environmental Protection Agency maximum contaminant levels, secondary maximum contaminant levels, and health advisory levels for analyzed constituents

3. Minimum, median, and maximum of well characteristics, physical and chemical properties, major ions, nutrients, and bacteria determined in the laboratory for water samples collected from 75 wells in Lycoming County, Pennsylvania, June-August 2014

4. Minimum, median, and maximum concentrations of metals and trace elements for water samples collected from 75 wells in Lycoming County, Pennsylvania, June-August 2014

5. Minimum, median, and maximum concentrations of radionuclides for water samples collected from 75 wells in Lycoming County, Pennsylvania, June-August 2014

6. Minimum, median, and maximum concentrations of methane and ethane determined in the laboratory for water samples collected from 75 wells in Lycoming County, Pennsylvania, June-August 2014

7. Reporting levels and drinking-water standards (U.S. Environmental Protection Agency, 2012) for manmade organic compounds analyzed in water samples collected from 75 wells in Lycoming County, Pennsylvania, June-August 2014

8. Principal components analysis of major factors controlling the chemistry of groundwater, Lycoming County, Pennsylvania, 2014 


\section{Conversion Factors}

U.S. customary units to International System of Units

\begin{tabular}{|c|c|c|}
\hline Multiply & By & To obtain \\
\hline \multicolumn{3}{|c|}{ Length } \\
\hline inch (in.) & 2.54 & centimeter $(\mathrm{cm})$ \\
\hline foot $(\mathrm{ft})$ & 0.3048 & meter (m) \\
\hline mile (mi) & 1.609 & kilometer (km) \\
\hline \multicolumn{3}{|c|}{ Area } \\
\hline square mile $\left(\mathrm{mi}^{2}\right)$ & 2.590 & square kilometer $\left(\mathrm{km}^{2}\right)$ \\
\hline \multicolumn{3}{|c|}{ Volume } \\
\hline gallon (gal) & 3.785 & liter (L) \\
\hline \multicolumn{3}{|c|}{ Flow rate } \\
\hline gallon per minute (gal/min) & 0.06309 & liter per second $(\mathrm{L} / \mathrm{s})$ \\
\hline \multicolumn{3}{|c|}{ Pressure } \\
\hline inch of mercury at $60^{\circ} \mathrm{F}$ (in $\mathrm{Hg}$ ) & 3.377 & kilopascal (kPa) \\
\hline \multicolumn{3}{|c|}{ Radioactivity } \\
\hline picocurie per liter $(\mathrm{pCi} / \mathrm{L})$ & 0.037 & becquerel per liter $(\mathrm{Bq} / \mathrm{L})$ \\
\hline
\end{tabular}

Temperature in degrees Celsius $\left({ }^{\circ} \mathrm{C}\right)$ may be converted to degrees Fahrenheit $\left({ }^{\circ} \mathrm{F}\right)$ as ${ }^{\circ} \mathrm{F}=$ $\left(1.8 \times{ }^{\circ} \mathrm{C}\right)+32$.

Temperature in degrees Fahrenheit $\left({ }^{\circ} \mathrm{F}\right)$ may be converted to degrees Celsius $\left({ }^{\circ} \mathrm{C}\right)$ as ${ }^{\circ} \mathrm{C}=$ $\left({ }^{\circ} \mathrm{F}-32\right) / 1.8$.

\section{Datum}

Vertical coordinate information is referenced to the North American Vertical Datum of 1988 (NAVD 88).

Horizontal coordinate information is referenced to the North American Datum of 1983 (NAD 83).

Altitude, as used in this report, refers to distance above the vertical datum. 


\section{Supplemental Information}

Specific conductance is given in microsiemens per centimeter at 25 degrees Celsius $(\mu \mathrm{S} / \mathrm{cm}$ at $\left.25^{\circ} \mathrm{C}\right)$.

Concentrations of chemical constituents in water are given either in milligrams per liter (mg/L) or micrograms per liter $(\mu \mathrm{g} / \mathrm{L})$.

\section{Abbreviations}

$\begin{array}{ll}{ }^{\circ} \mathrm{C} & \text { degrees Celsius } \\ = & \text { equal to } \\ > & \text { greater than } \\ \geq & \text { greater than or equal to } \\ < & \text { less than } \\ \leq & \text { less than or equal to } \\ \mu \mathrm{g} / \mathrm{L} & \text { micrograms per liter } \\ \mu \mathrm{S} / \mathrm{cm} & \text { microsiemens per centimeter } \\ \% \text { o } & \text { parts per thousand, or per mil* } \\ \mathrm{ALK} & \text { alkalinity } \\ \mathrm{DO} & \text { dissolved oxygen } \\ E . \text { coli } & \text { Escherichia coli } \\ \mathrm{EPA} & \text { U.S. Environmental Protection Agency } \\ \mathrm{HAL} & \text { health advisory level } \\ \text { IAP } & \text { ion activity product } \\ \mathrm{K}_{\mathrm{T}} & \text { Equilibrium constant for reaction at temperature T } \\ \mathrm{LI} & \text { Langelier Index } \\ \mathrm{MCL} & \text { maximum contaminant level } \\ \mathrm{mg} / \mathrm{L} & \text { milligrams per liter } \\ \mathrm{mmol} / \mathrm{L} & \text { millimoles per liter } \\ \mathrm{MPN} / 100 \mathrm{~mL} & \text { most probable number per 100 milliliters } \\ \text { NTRU } & \text { Nephelometric Turbidity Ratio Units } \\ \text { NWOL } & \text { National Water Quality Laboratory } \\ \mathrm{PC} & \text { principal component } \\ \mathrm{PCA} & \text { principal components analysis }\end{array}$

${ }^{*}$ The isotope ratio delta value $(\delta)$, in parts per thousand, or per mil $(\%)$, is defined as: $\delta E=\left[\left(R_{\text {sample }} / R_{\text {standard }}\right)-1\right] \bullet 1,000$ where $E$ is an element (in this report $C$ or $H$ ) and $R$ is the ratio of ${ }^{13} \mathrm{C} /{ }^{12} \mathrm{C}$ or ${ }^{2} \mathrm{H} /{ }^{1} \mathrm{H}$ in the sample or standard. The symbol $\mathrm{D}$ for deuterium is commonly used instead of ${ }^{2} \mathrm{H}$. 


$\begin{array}{ll}\mathrm{pCi} / \mathrm{L} & \text { picocuries per liter } \\ \text { redox } & \text { oxidation-reduction } \\ \text { ROE } & \text { residue on evaporation } \\ \mathrm{SC} & \text { specific conductance } \\ \mathrm{SI} & \text { Saturation Index } \\ \mathrm{SI}_{\text {CAL }} & \text { calcite Saturation Index } \\ \text { SLI } & \text { Seewald Laboratories Incorporated } \\ \text { SMCL } & \text { secondary maximum contaminant level } \\ \text { TDS } & \text { total dissolved solids } \\ \text { THM } & \text { trihalomethane } \\ \text { TPI } & \text { topographic position index } \\ \text { USGS } & \text { U.S. Geological Survey } \\ \text { VOC } & \text { volatile organic compound } \\ \text { VPDB } & \text { Vienna Pee Dee Belemnite } \\ \text { VSMOW } & \text { Vienna Standard Mean Ocean Water }\end{array}$





\title{
Groundwater Quality for 75 Domestic Wells in Lycoming County, Pennsylvania, 2014
}

\author{
By Eliza L. Gross and Charles A. Cravotta III
}

\section{Abstract}

Groundwater is a major source of drinking water in Lycoming County and adjacent counties in north-central and northeastern Pennsylvania, which are largely forested and rural and are currently undergoing development for hydrocarbon gases. Water-quality data are needed for assessing the natural characteristics of the groundwater resource and the potential effects from energy and mineral extraction, timber harvesting, agriculture, sewage and septic systems, and other human influences.

This report, prepared in cooperation with Lycoming County, presents analytical data for groundwater samples from 75 domestic wells sampled throughout Lycoming County in June, July, and August 2014. The samples were collected using existing pumps and plumbing prior to any treatment and analyzed for physical and chemical characteristics, including nutrients, major ions, metals and trace elements, volatile organic compounds, gross-alpha particle and gross beta-particle activity, uranium, and dissolved gases, including methane and radon-222.

Results indicate groundwater quality generally met most drinking-water standards, but that some samples exceeded primary or secondary maximum contaminant levels (MCLs) for arsenic, iron, manganese, total dissolved solids (TDS), chloride, $\mathrm{pH}$, bacteria, or radon-222. Arsenic concentrations were higher than the MCL of 10 micrograms per liter $(\mu \mathrm{g} / \mathrm{L})$ in 9 of the 75 (12 percent) well-water samples, with concentrations as high as $23.6 \mu \mathrm{g} / \mathrm{L}$; arsenic concentrations were higher than the health advisory level (HAL) of $2 \mu \mathrm{g} / \mathrm{L}$ in 23 samples (31 percent). Total iron concentrations exceeded the secondary maximum contaminant level (SMCL) of $300 \mu \mathrm{g} / \mathrm{L}$ in 20 of the 75 samples. Total manganese concentrations exceeded the SMCL of $50 \mu \mathrm{g} / \mathrm{L}$ in 20 samples and the HAL of $300 \mu \mathrm{g} / \mathrm{L}$ in 2 of those samples. Three samples had chloride concentrations that exceeded the SMCL of 250 milligrams per liter $(\mathrm{mg} / \mathrm{L})$; two of those samples exceeded the SMCL of $500 \mathrm{mg} / \mathrm{L}$ for TDS. The $\mathrm{pH}$ ranged from 5.3 to 9.15 and did not meet the SMCL range of 6.5 to 8.5 in 22 samples, with 17 samples having a $\mathrm{pH}$ less than 6.5 and 8 samples having $\mathrm{pH}$ greater than 8.5. Generally, the samples that had elevated TDS, chloride, or arsenic concentrations had high $\mathrm{pH}$.
Total coliform bacteria were detected in 39 of 75 samples (52 percent), with Escherichia coli detected in 10 of those 39 samples. Radon-222 activities ranged from non-detect to 7,420 picocuries per liter ( $\mathrm{pCi} / \mathrm{L}$ ), with a median of $863 \mathrm{pCi} / \mathrm{L}$, and exceeded the proposed drinking-water standard of $300 \mathrm{pCi} / \mathrm{L}$ in 50 (67 percent) of the 75 samples; radon-222 activities were higher than the alternative proposed standard of 4,000 $\mathrm{pCi} / \mathrm{L}$ in 3 samples.

Water from 15 of 75 (20 percent) wells had concentrations of methane greater than the reporting level of $0.01 \mathrm{mg} / \mathrm{L}$; detectable methane concentrations ranged from 0.04 to $16.8 \mathrm{mg} / \mathrm{L}$. Two samples had methane concentrations (13.1 and $16.8 \mathrm{mg} / \mathrm{L}$ ) exceeding the action level of $7 \mathrm{mg} / \mathrm{L}$. Low levels of ethane (up to $0.12 \mathrm{mg} / \mathrm{L}$ ) were present in the five samples with the highest methane concentrations (near or above $1 \mathrm{mg} / \mathrm{L}$ ) that were analyzed for hydrocarbon compounds and isotopic composition. The isotopic composition of methane in four of these groundwater samples, from the Catskill and Lock Haven Formations and the Hamilton Group, have sample carbon isotopic ratio delta values (carbon-13/ carbon-12) ranging from -42.36 to -36.08 parts per thousand $(\%)$ and hydrogen isotopic ratio delta values (deuterium/protium) ranging from -212.0 to $-188.4 \%$, which are consistent with the isotopic compositions reported for mud-gas logging samples from these geologic units and a thermogenic source of the methane. However, the isotopic composition and ratios of methane to ethane in a fifth sample indicate the methane in that sample may be of microbial origin that subsequently underwent oxidation. The fifth sample had the highest concentration of methane, $16.8 \mathrm{mg} / \mathrm{L}$, with an carbon isotopic ratio delta values of $-50.59 \%$ and a hydrogen isotopic ratio delta values of $-209.7 \%$.

The six well-water samples with the highest methane concentrations also had among the highest $\mathrm{pH}$ values (8.25 to 9.15) and elevated concentrations of sodium, lithium, boron, fluoride, arsenic, and bromide. Relatively elevated concentrations of some other constituents, such as barium, strontium, and chloride, commonly were present in, but not limited to, those well-water samples with elevated methane.

Three of the six groundwater samples with the highest methane concentrations had chloride/bromide ratios that indicate mixing with a small amount of brine $(0.02$ percent or less) similar in composition to those reported at undetermined 
depth below the freshwater aquifer and for gas and oil well brines in Pennsylvania. The sample with the highest methane concentration and most other samples with low methane concentrations (less than about $1 \mathrm{mg} / \mathrm{L}$ ) have chloride/bromide ratios that indicate predominantly anthropogenic sources of chloride, such as road-deicing salt, septic systems, and (or) animal waste. Brines that are naturally present may originate from deeper parts of the aquifer system, while anthropogenic sources are more likely to affect shallow groundwater because they occur on or near the land-surface.

The spatial distribution of groundwater compositions generally indicate that (1) uplands along the western border of Lycoming County usually have dilute, slightly acidic, oxygenated, calcium-bicarbonate type waters; (2) intermediate altitudes or areas of carbonate bedrock usually have water of near neutral $\mathrm{pH}$, with highest amounts of hardness (calcium and magnesium); (3) stream valleys, low elevations where groundwater may be discharging, and deep wells in uplands usually have water with $\mathrm{pH}$ values greater than 8 and highest arsenic, sodium, lithium, bromide concentrations. Geochemical modeling indicated that for samples with elevated $\mathrm{pH}$, sodium, lithium, bromide, and alkalinity, the water chemistry could have resulted by dissolution of calcite (calcium carbonate) combined with cation-exchange and mixing with a small amount of brine. Through cation-exchange reactions between water and bedrock, which are equivalent to processes in a water softener, calcium ions released by calcite dissolution are exchanged for sodium ions on clay minerals. Thus, the assessment of groundwater quality in Lycoming County indicates groundwater is generally of good quality, but various parts of Lycoming County can have groundwater with low to moderate concentrations of methane and other constituents that appear in naturally present brine and produced waters from gas and oil wells at high concentrations.

\section{Introduction}

Lycoming County, which is in north-central Pennsylvania, is mostly forested (fig. 1). Approximately 43 percent of the total population of Lycoming County relies on groundwater as a source of drinking water (Pennsylvania Department of Environmental Protection, 2013; U.S. Bureau of the Census, 2010). Publicly available data describing the chemical quality of groundwater from private domestic-supply wells in Lycoming County are needed for assessing natural characteristics of the groundwater resource and potential effects from activities such as coal and mineral mining, oil and gas extraction, timber harvesting, agriculture, sewage and on-lot septic systems, and other types of development. The Marcellus Shale, which is being developed for natural gas throughout northern and western Pennsylvania, lays thousands of feet below 85 percent of the land surface of Lycoming County(fig. 1; U.S. Geological Survey, 2002). Drilling and hydraulic fracturing of unconventional horizontal shale-gas wells, in addition to other human activities, have the potential to contaminate the base flow of streams and freshwater aquifers that provide drinking water (fig. 1; Kargbo and others, 2010; Kerr, 2010; U.S. Environmental Protection Agency, 2014).

Although hundreds of samples have been collected by the natural-gas industry to characterize the chemistry of groundwater in private wells of Lycoming County, few results from these samples are readily available to the public. Most of the publicly available results for groundwater-quality samples were collected more than 30 years ago (Lloyd and Carswell, 1981; Taylor and others, 1983) and do not include the broad suit of the current (2016) analytes of concern, such as total and fecal coliform bacteria, barium, strontium, chloride, bromide, hydrocarbon gases, trace metals, radon-222, and other radiochemicals (Pennsylvania Department of Environmental Protection, 2012). Without current data for associated groundwater-quality constituents, it is not possible to evaluate the sources of constituents or future potential groundwaterquality changes. Future changes in groundwater quality can be the result of natural variability or of human activities, including coal mining, oil and gas exploration, agricultural practices, onsite septic systems, or land development.

\section{Previous Investigations}

In the early 1980s, two published assessments of groundwater resources in the study area focused on hydrogeology and evaluated general groundwater quality, including major ions, nutrients, iron, and manganese. Lloyd and Carswell (1981) collected samples from 462 wells and 6 springs in a region surrounding Williamsport, Pennsylvania, which encompassed a large part of Lycoming County and small parts of Clinton, Union, Northumberland, and Montour Counties (fig. 1). The study by Lloyd and Carswell (1981) reported sample concentrations exceeding U.S. Environmental Protection Agency (EPA) standards for iron, manganese, sulfate, chloride, dissolved solids, hydrogen sulfide, barium, cadmium, lead, nitrate, and zinc. The study by Taylor and others (1983) reported major ion and trace-metal concentrations for 47 samples from wells in Lycoming County. Taylor and others (1983) concluded that primarily calcareous (carbonate) and primarily noncalcareous rock units had the most major differences in natural groundwater chemistry. Their results indicated that some groundwater was affected by high concentrations of iron and manganese, hydrogen sulfide, hardness, nitrate, and (or) bacterial organisms resulting from natural sources combined with contamination by sewage, agricultural practices, acid mine drainage, petroleum products from buried storage tanks, and (or) landfill leachate.

Recent studies of potential effects of gas drilling on groundwater quality from domestic wells in Lycoming and nearby counties in north-central and northeastern Pennsylvania reported that some samples had elevated concentrations of methane, sodium, chloride, bromide, and other dissolved constituents (Warner and others, 2012; Llewellyn, 2014; Siegel 




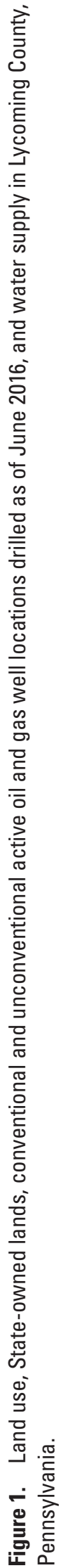


and others, 2015; Reilly and others, 2015). Instead of contamination of shallow aquifers by flowback fluids from gas drilling and fracturing processes, these studies identified naturally present saline groundwater as the primary source of salinity in the sampled domestic wells. Such saline groundwater, which commonly contains methane, has been reported historically in Pennsylvania (Poth, 1962; Feth, 1965). Results also indicated that in addition to, or instead of, the influence of natural brines or other natural sources, some groundwater samples had been contaminated by animal waste, septic waste, or road-deicing salt (Llewellyn, 2014; Reilly and others, 2015). Thus, current water-quality data are needed for assessing natural characteristics and potential effects from mining, oil and gas extraction, forestry, agriculture, sewage or septic disposal, and other activities.

\section{Purpose and Scope}

This report, prepared in cooperation with Lycoming County, presents analytical data for groundwater samples from 75 domestic wells sampled throughout Lycoming County, Pennsylvania in June, July, and August 2014. The water samples were analyzed for nutrients, major ions, metals and trace elements, volatile organic compounds (VOCs), alcohols, gross-alpha particle and gross beta-particle activity, uranium, and dissolved gases, including methane and radon-222. A subset of 10 samples was analyzed for the radium isotopes radium-226 and radium-228. A subset of samples that had relatively elevated methane concentrations (approximately $1 \mathrm{mg} / \mathrm{L}$ and higher) was analyzed for the isotopic composition of methane and the concentrations of associated higher-chain hydrocarbons. Measured concentrations of analyzed constituents in groundwater are compared to EPA drinking-water standards. The relations among observed groundwater-quality characteristics, geology, topographic setting, land use, and other environmental variables associated with sampled wells are evaluated. The groundwater-quality data, summary statistics, and geochemical computations are presented to further the understanding of the current chemical quality of groundwater from freshwater aquifers used by private domestic-supply wells in Lycoming County and to update and fill the gap in existing groundwater-quality data.

\section{Description of Study Area}

Lycoming County occupies roughly 1,244 square miles in north-central Pennsylvania (fig. 1). Land surface elevations range from 452 feet above the North American Vertical Datum of 1988 (NAVD 88) in the south central area where the West Branch Susquehanna River flows out of Lycoming County to 2,404 feet above the NAVD 88 in the northeast part of the county (U.S. Geological Survey, 2009). Average annual temperatures in Lycoming County range from about 45 to 50 degrees Fahrenheit with the valley of the West Branch
Susquehanna River having the warmest average annual temperatures and the mountainous areas in the northeastern part of the county having the coldest average annual temperatures (PRISM Group at Oregon State University, 2006a, 2006b). Average annual precipitation varies from an average of 37 inches in the northwestern part of county to an average of 50 inches in the south central part of the county (PRISM Oregon State University, 2006c).

\section{Population, Water Supply, and Land Use}

Lycoming County is largely rural with a total population of 116,111 recorded in 2010 (U.S. Bureau of the Census, 2011). Seasonal dwellings made up an estimated 9 percent of housing units in the county in 1999 (Lycoming County Planning Commission, 2001). Some of the most densely populated areas in the county include the city of Williamsport and the boroughs of South Williamsport, Montoursville, Jersey Shore, Muncy, Hughesville, and Montgomery (fig. 1) with 2010 populations of 29,$381 ; 6,379 ; 4,615 ; 4,361 ; 2,477 ; 2,128$; and 1,579 , respectively (U.S. Bureau of the Census, 2011). About 6 percent of the county consists of developed land, and these areas are also where population densities are highest (fig. 1). Developed areas with high population density commonly include public water supply service (fig. 1; Pennsylvania Department of Environmental Protection, 2013). In the less populated areas, residents use groundwater wells as their source of domestic water supply. Approximately 97 percent of Lycoming County is outside of public water supply service areas, and 43 percent of the total population within the county is assumed to be using a self-supplied water supply (Pennsylvania Department of Environmental Protection, 2013; U.S. Bureau of the Census, 2010).

Outside of the more densely populated areas in Lycoming County, agricultural lands account for about 18 percent of the land area and are typically found in the narrow valley bottoms in the northern part of the county and throughout the valley of the West Branch Susquehanna River in the southern part of the county. In addition, about 76 percent of the county is forested with approximately 42 percent of forested land consisting of State parks, forests, and gamelands in the northern half of the county (fig. 1; U.S. Geological Survey, 2014).

Forested, agricultural, and State-owned parts of the county also coincide with locations of both conventional and unconventional active oil and and gas wells. Unconventional wells were not drilled in the county until more recently (after 2007) than conventional wells, which were drilled as early as the 1800's (fig. 1). Unconventional wells differ from conventional wells because they are purposely drilled into geologic shale formations where natural gas generally cannot be produced at economic flow rates or volumes without vertical or horizontal well bores being stimulated by hydraulic fracture treatments or by using multilateral well bores or other techniques to expose more of the geologic shale formation to the well bore (Pennsylvania Department of Environmental Protection, 2016). 


\section{Physiography and Geologic Setting}

The northern two-thirds of Lycoming County is in the Appalachian Plateaus Physiographic Province, whereas the southern one-third of the county is in the Ridge and Valley Physiographic Province (Pennsylvania Bureau of Topographic and Geologic Survey, 1998). The northernmost parts of the county are in a glaciated area (fig. 2) known as the Glaciated Low Plateau and Glaciated High Plateau Sections of the Appalachian Plateaus Physiographic Province, which are characterized by broad to narrow, rounded to flat, elongated uplands and shallow valleys. South of this glaciated area is the Deep Valleys Section of the Appalachian Plateaus Physiographic Province, which is characterized by very deep, angular valleys with some broad to narrow uplands. South of the relatively flat-lying rocks of the Appalachian Plateaus is the Appalachian Mountain section of the Ridge and Valley Physiographic Provice, which is characterized by narrow to broad valleys with steep uplands or linear ridge and mountain tops.
Lycoming County is underlain by 23 mapped geologic units (fig. 2 and table 1) ranging in age (youngest to oldest) from Pennsylvanian to Mississippian, Devonian, Silurian, to Ordovician (Pennsylvania Bureau of Topographic and Geologic Survey, 2001). Alluvium and glacial outwash and drift overlie the bedrock in major stream valleys. In some areas, the alluvium, which consists of gravel, sand, and clay that fills some valleys to depths of more than 200 feet, has been transported relatively long distances as a result of glacial processes (outwash), and in other areas, it has been weathered from the nearby rock formations (Taylor and others, 1983). For the purposes of this study, the 23 geologic units cropping out in Lycoming County were divided into four principal lithologic classes, consisting of carbonate, shale, siltstone, or sandstone lithology, based on the primary lithology reported by the Pennsylvania Bureau of Topographic and Geologic Survey (2001) and additional lithologic and water-quality descriptions from Taylor and others (1983; fig. 3 and table 1).

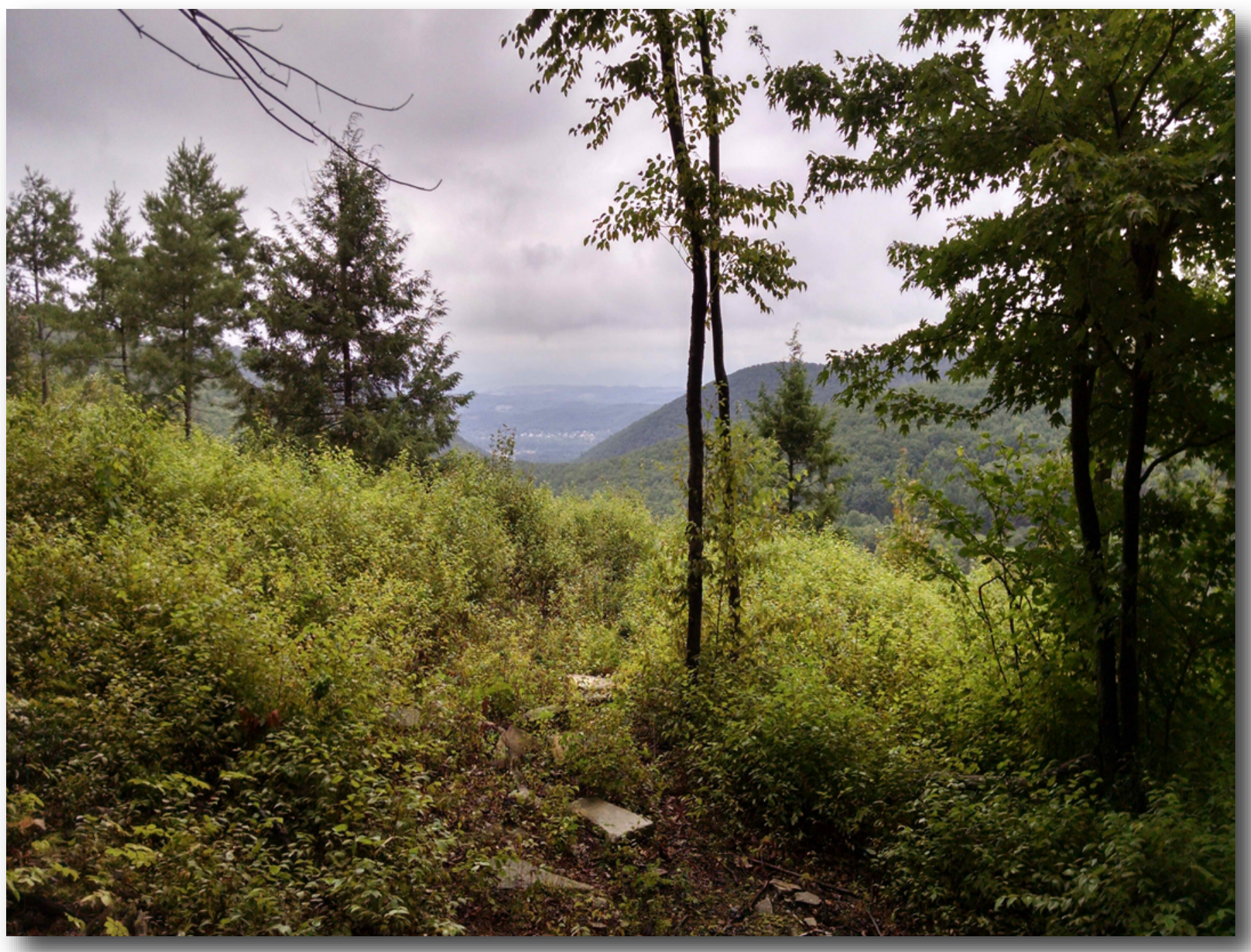

Example of common topographic features in the Ridge and Valley Physiographic Province of Bastress Township, Lycoming County, Pennsylvania. (Photograph provided by Brian Renninger, Bastress Township, Lycoming Conservation District) 





Table 1. Geologic units grouped by lithologic class based on geologic unit characteristics, including name, map symbol, age, and primary lithology from Pennsylvania Bureau of Topographic and Geologic Survey (2001) and additional lithologic and water quality descriptions from Taylor and others (1983).

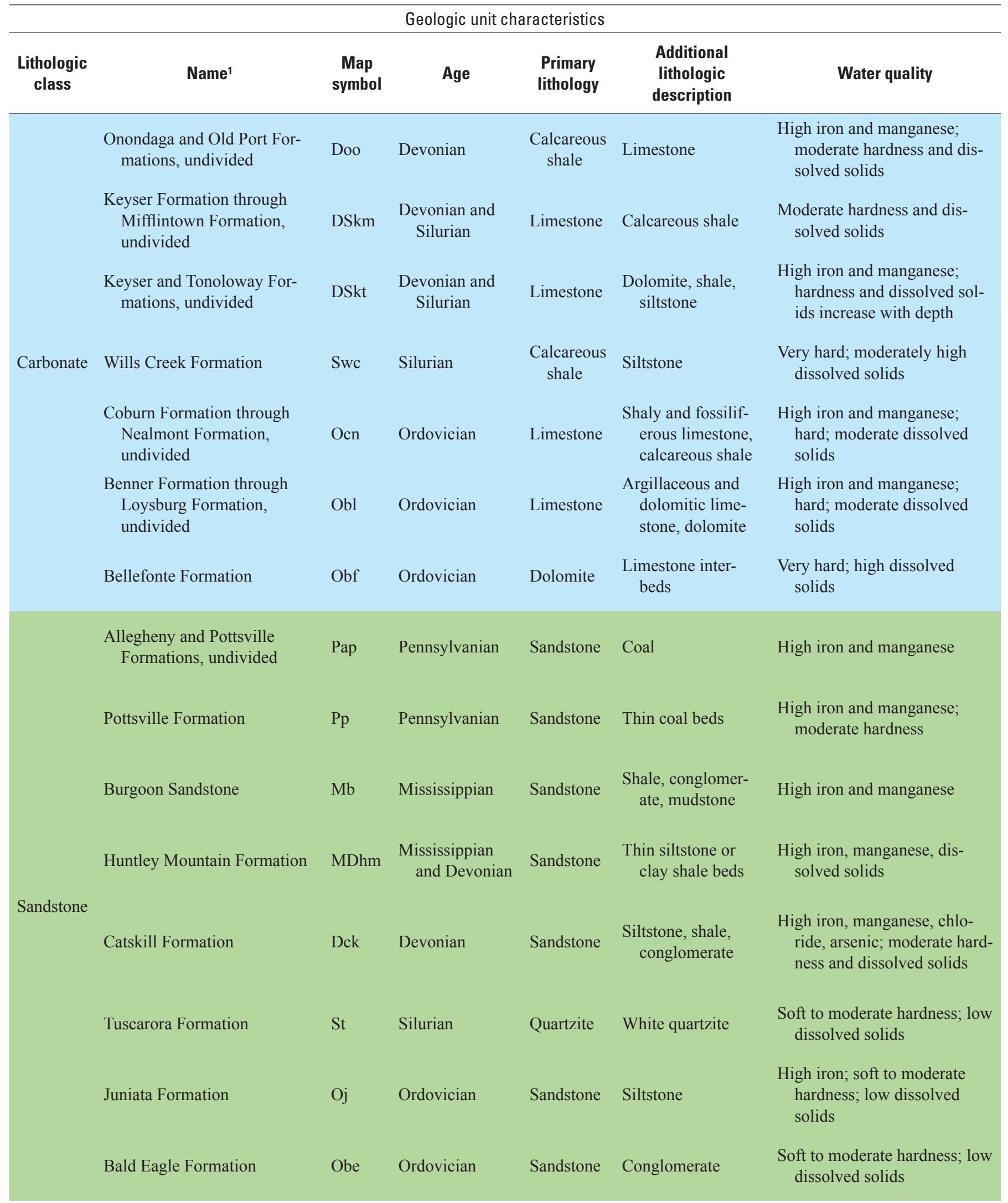


Table 1. Geologic units grouped by lithologic class based on geologic unit characteristics, including name, map symbol, age, and primary lithology from Pennsylvania Bureau of Topographic and Geologic Survey (2001) and additional lithologic and water quality descriptions from Taylor and others (1983).-Continued

\begin{tabular}{|c|c|c|c|c|c|c|}
\hline \multicolumn{7}{|c|}{ Geologic unit characteristics } \\
\hline $\begin{array}{l}\text { Lithologic } \\
\text { class }\end{array}$ & Name $^{1}$ & $\begin{array}{c}\text { Map } \\
\text { symbol }\end{array}$ & Age & $\begin{array}{l}\text { Primary } \\
\text { lithology }\end{array}$ & $\begin{array}{l}\text { Additional } \\
\text { lithologic } \\
\text { description }\end{array}$ & Water quality \\
\hline \multirow{4}{*}{ Shale } & Mauch Chunk Formation & $\mathrm{Mmc}$ & Mississippian & Shale & $\begin{array}{l}\text { Sandstone, silt- } \\
\text { stone, mudstone }\end{array}$ & Moderate dissolved solids \\
\hline & $\begin{array}{l}\text { Hamilton Group (contains } \\
\text { Mahantango and Marcellus } \\
\text { Formations) }\end{array}$ & $\mathrm{Dh}$ & Devonian & Shale & Siltstone, limestone & $\begin{array}{l}\text { High iron and manganese; } \\
\text { moderate hardness }\end{array}$ \\
\hline & Clinton Group & $\mathrm{Sc}$ & Silurian & Shale & $\begin{array}{l}\text { Siltstone and sand- } \\
\text { stone interbeds }\end{array}$ & $\begin{array}{l}\text { High iron and manganese; soft } \\
\text { to moderate hardness; low } \\
\text { dissolved solids }\end{array}$ \\
\hline & Reedsville Formation & Or & Ordovician & Shale & $\begin{array}{l}\text { Siltstone, sandstone } \\
\text { interbeds }\end{array}$ & $\begin{array}{l}\text { Hard; moderate dissolved } \\
\text { solids; hydrogen sulfide }\end{array}$ \\
\hline \multirow{2}{*}{ Siltstone } & $\begin{array}{l}\text { Brallier and Harrell Forma- } \\
\text { tions, undivided }\end{array}$ & Dbh & Devonian & Siltstone & Shale, sandstone & $\begin{array}{l}\text { High iron and manganese; } \\
\text { moderate dissolved solids }\end{array}$ \\
\hline & Trimmers Rock Formation & Dtr & Devonian & Siltstone & Shale & $\begin{array}{l}\text { High iron and manganese; } \\
\text { moderate hardness; low dis- } \\
\text { solved solids }\end{array}$ \\
\hline
\end{tabular}

\footnotetext{
${ }^{1}$ Geologic unit names from Pennsylvania Bureau of Topographic and Geologic Survey (2001)
} 


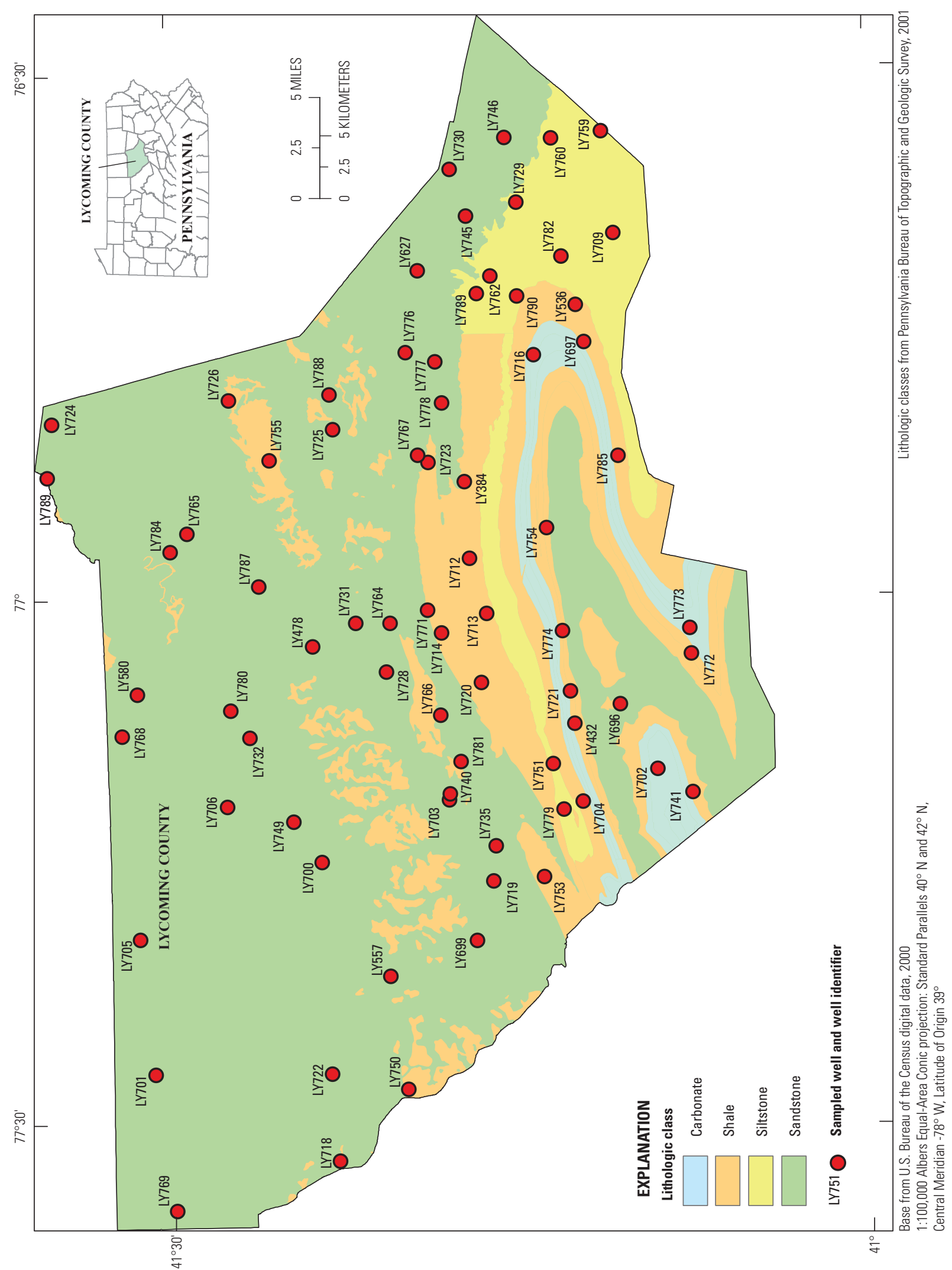




\section{Study Methods}

To provide current data on methane and quality of groundwater used for water supply in Lycoming County, groundwater samples were collected from 75 domestic wells during summer months in 2014 (fig. 3). One sample from each well was analyzed for nutrients, major ions, metals and trace elements, VOCs, ethylene and propylene glycol, alcohols, radioactivity, bacteria, and dissolved gases, including methane and radon-222.

\section{Selection of Sampling Locations}

Selection of wells for sampling involved several steps: (1) establishing an area of interest within the Lycoming County study area, (2) applying a stratified random selection program for site selection (Scott, 1990), (3) obtaining well location and construction record data (Pennsylvania Bureau of Topographic and Geologic Survey, 2014), (4) establishing well selection criteria, (5) identifying potential wells for sampling, (6) contacting well owners, and (7) conducting a plumbing review. The stratified random site-selection procedure permits the estimation of the probability of finding a small target. Given a grid of 75 cells, a small target is unlikely to be detected if it is present in less than 0.1 percent of the aquifer system, but is unlikely to be missed (at the 90-percent confidence interval) if it occupies more than 3 percent of the aquifer (Belitz and others, 2010). Because domestic wells in Lycoming County were being targeted for sampling, it was necessary to establish an area of interest within the relatively undeveloped parts of the county where domestic wells are the predominant source of water supply (fig. 1). State-owned lands, including State parks, forests, and gamelands, were excluded from the area of interest in order to remove widely unpopulated areas of the county from the site-selection process. In addition, those areas in Lycoming County serviced by public water suppliers were excluded from the area of interest because domestic wells in those areas would no longer be in use because those homes were assumed to be serviced by a public water supplier. Once an area of interest was defined for domestic well selection, a computerized stratified random site-selection approach was used to design a groundwaterquality network for sampling (Scott, 1990). An equal-area site-selection method was used to create an equal-area grid of cells and equally spaced population of potential sites, and the program arbitrarily specified one site from each cell as a primary sampling point and three additional sites as alternate sampling locations. Next, well record data within the defined area of interest in Lycoming County were obtained from the Pennsylvania Groundwater Information System database (Pennsylvania Bureau of Topographic and Geologic Survey, 2014), and potential wells for sampling were selected from these data based on the following criteria: the well is used for domestic or stock purposes; the well has an associated drill record or the homeowner knows well depth and construction information; the well was drilled after 1970; the well was not hand dug; and the top of the casing is above the land surface. The latter criterion helped to eliminate shallow wells completed in alluvium or glacial outwash areas. Wells located within 1 mile of one of the computer generated random sampling points were prioritized. Homeowner contact information was obtained for those properties containing well records meeting the selection criteria, and homeowners were contacted to set up an appointment for a plumbing review. During the plumbing review, a U.S. Geological Survey (USGS) employee located the well, collected descriptive and spatial information about the well, made sure that the well met the criteria listed above, verified that a raw and untreated sample representative of the underground aquifer would be able to be collected, and obtained homeowner permission for future sample collection. Wells meeting the criteria listed above were prioritized for sampling, and not all wells that received plumbing reviews were sampled. All wells selected for sampling were private domestic wells.

\section{Collection and Analysis of Samples}

Groundwater samples from 75 wells were collected from June 9 through August 28, 2014 using established methods that attempt to characterize conditions within the aquifer (U.S. Geological Survey, variously dated). The water samples were collected using existing pumps and plumbing. Any watertreatment systems, including filtration, water softening, or bacteriological treatment were bypassed by attaching Teflon tubing to a raw-water tap at a pressure tank or outdoor faucet. If possible, a water level measurement was recorded at the well prior to pumping. Field measurements of physical and chemical properties $(\mathrm{pH}$, temperature, specific conductance [SC], dissolved oxygen [DO] concentration, and turbidity) were conducted using a multiparameter probe that was immersed in gently flowing water. Wells were purged until the field measurements reached stable values and then samples were collected following USGS protocols (U.S. Geological Survey, variously dated). Alkalinity was measured the day of sampling with most measurements occurring at the hotel and several in the field.

Unfiltered subsamples without added preservatives were collected for physical properties, radioactivity, and dissolved gases. Filtered water samples, using sample-rinsed disposable 0.45 -micrometer pore size cellulose capsule filters, and corresponding unfiltered samples were preserved with nitric acid for subsequent analysis of major ions, metals, and trace elements. Samples for radon-222 analysis were obtained through an inline septum with a gas-tight syringe to avoid atmospheric contact.

Unfiltered samples were stored on ice in coolers until hand delivered to Seewald Laboratories Incorporated (SLI) in Williamsport, $\mathrm{Pa}$ for analyses of bacteria, methane and other hydrocarbon gases, oil and grease, VOCs, ethylene and propylene glycol, alcohols, Total Kjeldahl nitrogen, and total 
concentrations of major ions, metals, and trace elements. The remaining samples were shipped by overnight delivery to the following laboratories: (1) the USGS National Water Quality Laboratory (NWQL) in Denver, Colorado, for analysis of major ions, nutrients, metals, trace elements, and radon-222; (2) TestAmerica, Inc., in Richland, Washington, for analysis of gross alpha and beta radioactivity for all wells and radium-226 and radium-228 for a subset of wells; and (3) Isotech, Inc., in Champaign, Illinois, for analysis of dissolved methane, associated higher-chain hydrocarbons, and isotopes of hydrogen and carbon in methane, explained below. Dissolved gas amounts were reported in terms of mole percent in headspace for the water sample, and also for methane and ethane as a dissolved concentration. Descriptions of analytical methods for constituents analyzed by the USGS NWQL are available through U.S. Geological Survey (variously dated). The analytical results for all of the field and laboratory measurements completed for this study are available through the USGS National Water Information System (U.S. Geological Survey, 2015). To facilitate access to these data, the official station numbers and selected descriptive information for the sampled wells are listed in the appendix table 1-1.

The concentrations of major ions typically are reported in milligrams per liter, which are approximately equivalent to parts per million. Nitrogen compounds, such as nitrate and ammonia, are reported in milligrams per liter as nitrogen, and phosphorus compounds, such as orthophosphate, are reported in milligrams per liter as phosphorus. The concentrations of trace elements and organic compounds typically are reported in micrograms per liter, which are approximately equivalent to parts per billion; a concentration value of 1,000 micrograms per liter $(\mu \mathrm{g} / \mathrm{L})$ is equal to 1.0 milligram per liter $(\mathrm{mg} / \mathrm{L})$. The most commonly used unit for reporting radon-222 and other radioactivity in water is picocuries per liter, explained in more detail where the data are presented.

Water samples containing a sufficient concentration of methane, generally greater than $0.9 \mathrm{mg} / \mathrm{L}$, were further analyzed at Isotech, Inc., for the stable carbon isotopes (carbon-12 and carbon-13) and the stable hydrogen isotopes (protium and deuterium). The carbon-13/carbon-12 ratio and deuterium/protium ratios were determined by a mass spectrometric analysis that compared the sample to a reference standard. The carbon isotope ratio value in methane is reported in terms of parts per thousand (\%) with respect to the Vienna Pee Dee Belemnite (VPDB) standard. The hydrogen isotope ratio value in methane is reported in terms of \%o with respect to the Vienna Standard Mean Ocean Water (VSMOW) standard.

\section{Quality Assurance and Quality Control}

For quality control, one equipment blank was analyzed before the sampling season began; filtered and unfiltered replicate samples were collected from wells, LY701, LY712, LY745, and LY789; a field blank was processed onsite at LY536; and a standard reference sample was processed at SLI.
Field blank samples were submitted to SLI and USGS NWQL to be analyzed for major ions, nutrients, metals and trace elements, and manmade organic compounds. Replicate samples were submitted to SLI to be analyzed for major ions and manmade organic compounds. Additional samples were collected from well LY745 to compare analytical results for manmade organic compounds between USGS NWQL and SLI. Equipment and field blanks demonstrated that the tubing, filtration apparatus, and other sample processing steps did not add contaminants to the samples, because results for all constituents were less than the minimum reporting levels. Results from replicate samples indicate that combined sampling and analytical precision (reproducibility) was within 5 percent for all major ions and most trace elements at concentrations that were greater than two times the minimum reporting level. Within two times the minimum reporting level, the concentrations were less precise but still within 20 percent. For the replicate sample collected from LY789, copper was $36.95 \mu \mathrm{g} / \mathrm{L}$ greater than the environmental sample concentration (100-percent increase), and zinc was $5.743 \mu \mathrm{g} / \mathrm{L}$ greater than the environmental sample concentration (272-percent increase). Samples collected from LY745 and analyzed at both USGS NWQL and SLI were comparable, with most results being less than the minimum reporting levels.

For quality assurance of the inorganic chemical analyses, intrasample characteristics were evaluated using standard procedures described by Hem (1985) and Fishman and Friedman (1989). Evaluations of accuracy and precision included comparison of field- and laboratory-measured values for $\mathrm{pH}$ and SC for each sample, along with a comparison of the concentrations of constituents in the unfiltered (total) and filtered (dissolved) subsamples. Generally, the field- and laboratorymeasured values were consistent with one another, and the total concentrations of a constituent were greater than or equal to the dissolved concentration.

Additional quality control and quality assurance checks involved comparisons of the computed cation and anion equivalents concentrations and the corresponding ionic charge balance, comparisons of the ratios of cation or anion equivalents to SC, and comparisons of total dissolved solids (TDS) computed as the sum of major ion concentrations to the measured residue on evaporation (ROE) at 180 degrees Celsius $\left({ }^{\circ} \mathrm{C}\right)$. Deviations in the ionic charge balance that could be attributed to errors in the measured alkalinity were evaluated by computing the alkalinity concentration to achieve an ionic charge balance. The alkalinity is a potentially significant source of ionic imbalance because bicarbonate generally is the predominant ion in freshwater samples (Hem, 1985). Lastly, the measured SC was compared to the computed SC, which was estimated as the sum of ionic conductivities after accounting for aqueous speciation (McCleskey and others, 2012).

The values of SC measured in the field and laboratory were consistent with one another, and with the computed values of SC and TDS on the basis of measured solute concentrations (fig. $4 A$ and $F$ ). The measured TDS concentration as ROE by two different laboratories and the computed TDS as 

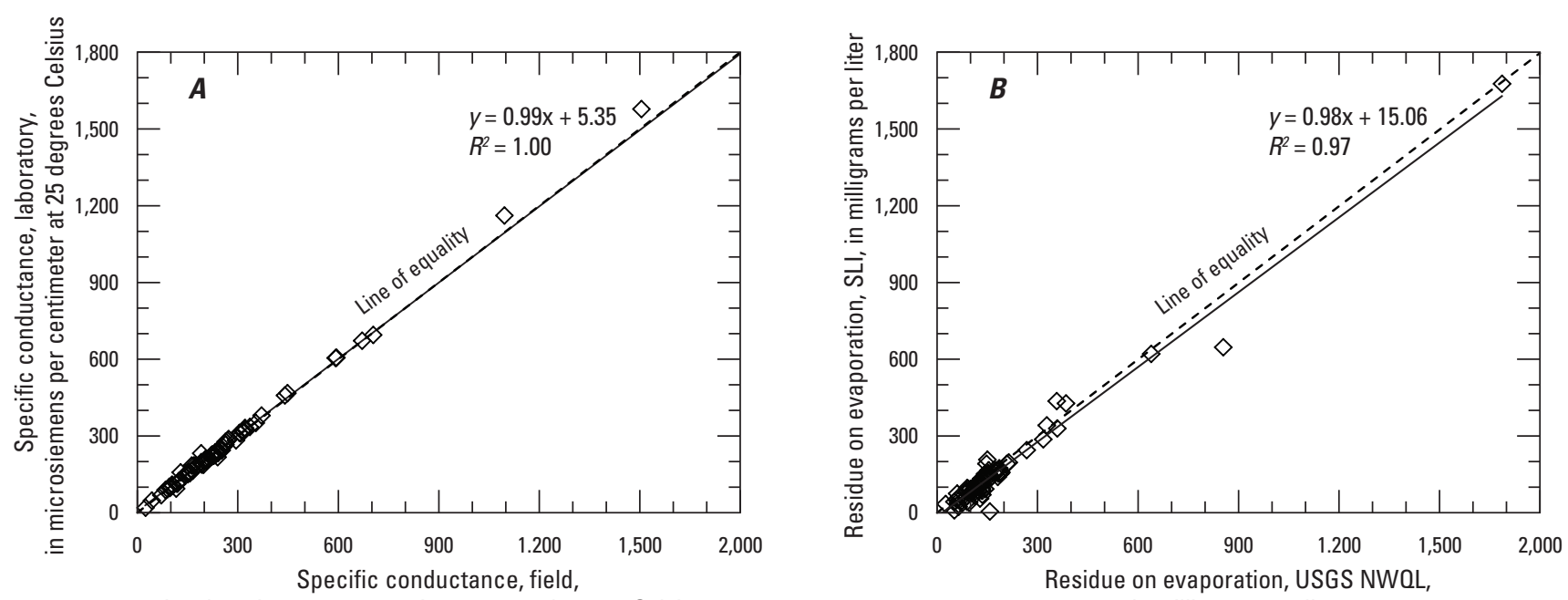

in microsiemens per centimeter at 25 degrees Celsius
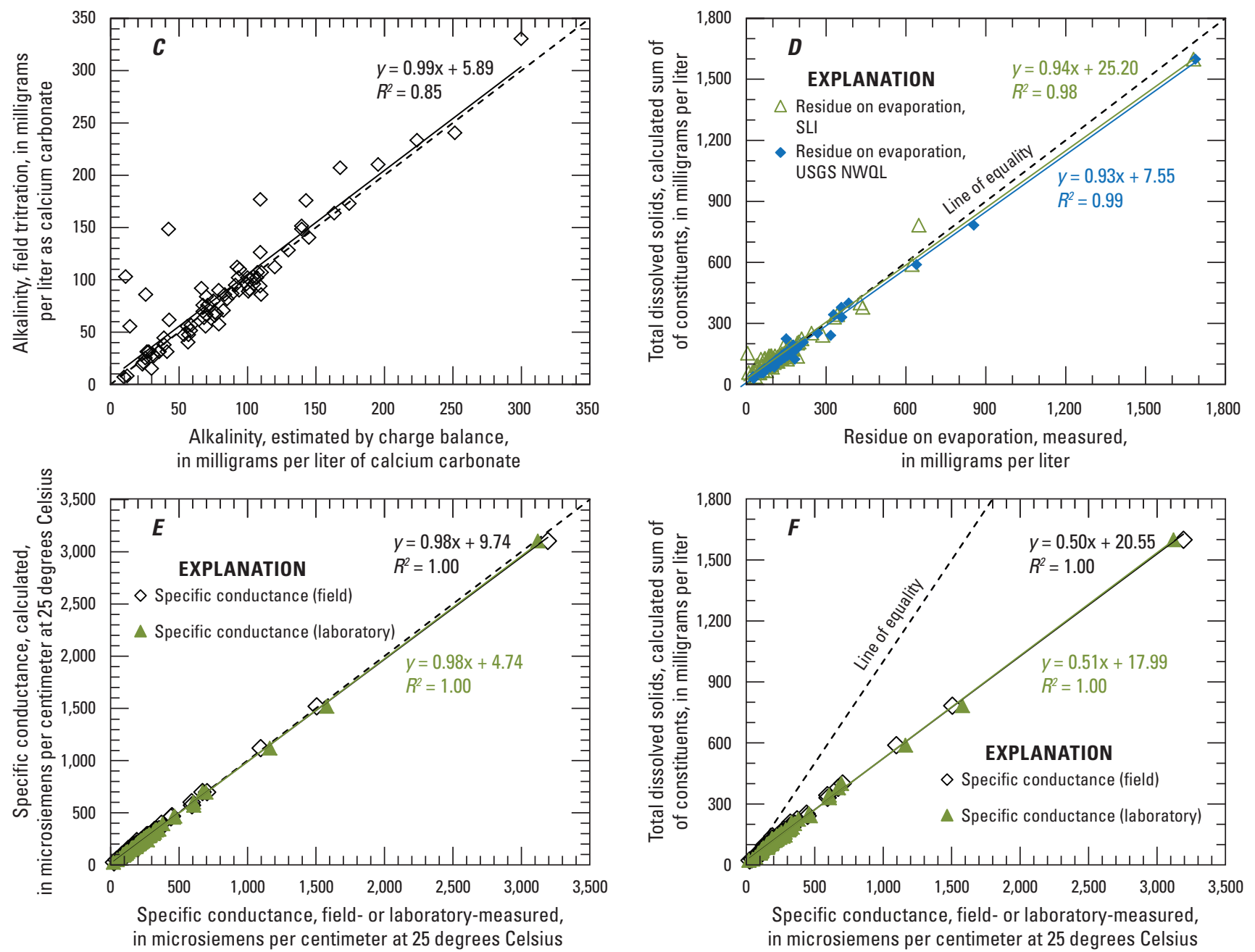

Figure 4. Comparison of field, laboratory, and (or) computed values of specific conductance (SC), total dissolved solids (TDS), or alkalinity for 75 groundwater samples from Lycoming County, Pennsylvania, 2014. $A$, field- and laboratory-measured SC; $B$, measured TDS as residue on evaporation (ROE) at 180 degrees Celsius by two different laboratories; $C$, alkalinity measured by incremental titration in the field and the computed value, estimated to achieve ionic charge balance; $D$, measured TDS (as ROE) and calculated TDS as the sum of dissolved constituent concentrations, including the estimated alkalinity; $E$, field- or laboratory-measured SC and calculated SC on the basis of ionic conductivities; and $F$, field- or laboratory-measured SC and calculated TDS on the basis of dissolved constituent concentrations. [SLI, Seewald Laboratories Incorporated; USGS, U.S. Geological Survey; NWOL, National Water Quality Laboratory] 
the sum of constituent concentrations were in close agreement (figs. $4 B$ and $D$ ). The computed TDS considered an estimated concentration of alkalinity to achieve ionic charge balance instead of the measured alkalinity value (figs. $4 B$ and $4 D$ ). The estimated alkalinity concentration and the corresponding measured alkalinity for most samples were in close agreement (fig. 4C); however, several of the measured alkalinity values produced excessive charge imbalances and were inconsistent with other measures such as the measured SC and TDS. Therefore, the estimated alkalinity concentration was used for subsequent evaluations that considered the major ion data.

\section{Graphical and Statistical Analyses}

Various graphical and statistical techniques were used in this report to compare water-quality data among different sites, to distinguish natural and anthropogenic sources of dissolved constituents, and to identify possible factors affecting the amount or transport of solutes in the aquifers in the study area. Bivariate scatter plots were created to illustrate potential relations among $\mathrm{pH}$, selected constituent concentrations, and the saturation index values for minerals that may be sources or controls of the constituents. Additional plots of the mass ratio of chloride to bromide and the concentrations of bromide or sodium compared to the concentration of chloride were created to illustrate potential for different sources of salinity, including road-deicing salts and brines from oil and gas operations (Mullaney and others, 2009; Whittemore, 2007). Likewise, major ion data were plotted on trilinear diagrams and Piper diagrams (Appelo and Postma, 2005; Back, 1966; Hem, 1985) to illustrate the range of compositions of the samples collected for this study and possible processes such as calcite dissolution, cation-exchange, and mixing with roaddeicing salt or brine that could produce the observed variations in major ions. The Piper diagrams were generated using the Geochemist's Workbench computer program (Bethke and Yeakel, 2010).

In general, nonparametric, rank-based statistical approaches were used to accommodate non-normally distributed and censored (below detection) data typical of most environmental samples (Helsel and Hirsch, 2002). Data for chemical concentrations were censored to a common level, and censored values were set to a common lowest value before ranks were computed for use in statistical tests. Relations between chemical variables were evaluated with scatter plots and correlation coefficients (Spearman's rho); distributions were compared among different sample classifications using notched boxplots (Velleman and Hoaglin, 1981; Helsel and Hirsch, 2002; P-STAT, Inc., 2008). Statistically significant correlation coefficients are presented in appendix table $2-1$, and boxplots are presented in appendix 3 . Where the median for a group is greater than the common reporting limit, it is displayed as a horizontal line within the box that is defined by the 25th and 75th percentiles for that group; otherwise, the median is displayed at the reporting limit. If the notched intervals around the medians for sample subsets do not overlap, the medians are statistically different at the 95-percent confidence interval.

The boxplots in appendix 3 considered pH (fig. 3-1), SC (fig. 3-2), oxidation-reduction state (redox; fig. 3-3), and lithologic class (fig. 3-4) variables to classify and subset the data. The redox classifications used in this report were based on concentration thresholds of McMahon and Chapelle (2008) but were simplified to consider only three major classes: (1) "anoxic" (DO less than $[<] 0.5 \mathrm{mg} / \mathrm{L}$ ); (2) "mixed" (DO greater than $[>] 0.5 \mathrm{mg} / \mathrm{L}$ and either manganese $>50 \mu \mathrm{g} / \mathrm{L}$ or iron $>100 \mu \mathrm{g} / \mathrm{L}$ ); or (3) "oxic" (DO $>0.5 \mathrm{mg} / \mathrm{L}$, manganese $<50 \mu \mathrm{g} / \mathrm{L}$, and iron $<100 \mu \mathrm{g} / \mathrm{L}$ ). The topographic position index (TPI) was computed on the basis of a 25 -meter digital elevation model (U.S. Geological Survey, 2009) using criteria reported by Llewellyn (2014) to indicate six potential classes for topographic setting: (1) ridge, (2) upper slope, (3) steep slope, (4) gentle slope, (5) lower slope, or (6) valley. No samples were collected from the steep slope TPI category. Furthermore, relations among the constituent concentrations and TPI classes were not apparent from the boxplots, and therefore, boxplots using TPI classifications are not included in the appendix.

Principal components analysis (PCA), computed with SAS 9.2 (SAS Institute, Inc., 2012), was used to evaluate multivariate correlations among the system variables $(\mathrm{pH}$, $\mathrm{SC}$, temperature) and dissolved constituents in the regional groundwater dataset without prior classification. The goal was to identify important hydrochemical processes or master variables that could explain element associations and distributions (Joreskog and others, 1976; Drever, 1997; Thyne and others, 2004). The Spearman-rank correlation coefficient matrix for the groundwater dataset (table 2-1) provided the standardized input for the PCA. Before computing ranks for the correlation analysis, censored values were set to a factor of 0.99 of the highest common reporting level (e.g. bromide $<0.03 \mathrm{mg} / \mathrm{L}$ was changed to bromide equal to [ $=] 0.0299 \mathrm{mg} / \mathrm{L}$ ). Although bromide was included in the PCA, other constituents that were censored in more than 40 percent of the samples were excluded, including dissolved methane, organic nitrogen, and various trace elements. Only one variable was included for constituents that were considered redundant, such as field- and laboratory- measured values for $\mathrm{pH}$ or $\mathrm{SC}$, or autocorrelated (not independent) variables, such as hardness and concentrations of calcium and magnesium. The PCA was optimized with varimax rotation to maximize the differences among the principal components; only principal components with eigenvalues greater than unity, equivalent to correlations with a probability greater than or equal to $(\geq) 0.999$, were retained (Joreskog and others, 1976; Thyne and others, 2004). Loadings for each constituent included in the PCA are equivalent to the Spearman-rank correlation coefficient between that constituent and the principal component. To aid in interpretations, the scores for each principal component in the PCA were compiled and then evaluated by correlation or graphical analysis with additional variables that had not been included 
in the PCA, such as land surface elevation, well depth and bottom elevation, and the excluded trace elements. For simplification of displayed results, the loading values and Spearmanrank correlation coefficient values are multiplied by 100 and rounded. Significant correlation coefficients for the additional variables are displayed beneath the main PCA results; only correlation coefficients with probability $\geq 0.999$ are considered significant.

Aqueous speciation computations were conducted with PHREEQC (Parkhurst and Appelo, 2013), a computer program designed to perform a wide variety of aqueous geochemical calculations based on equilibrium chemistry of aqueous solutions interacting with minerals, gases, solid solutions, exchangers, and sorption surfaces. Thermodynamic data for the aqueous species and gas and mineral phases from the wateq4f.dat database file were included. The wateq4f.dat database file is derived from the WATEQ4F ion-association aqueous model (Ball and Nordstrom, 1991), which uses field measurements (e.g. temperature, $\mathrm{pH}, \mathrm{DO}$, alkalinity) and the chemical analysis of a water sample as input to calculate the distribution of aqueous species, ion activities, and mineral saturation indices that indicate the tendency of a water to dissolve or precipitate a set of minerals (Drever, 1997; Nordstrom and Munoz, 1986). In addition to data from the wateq4f.dat database file, cation-exchange equilibrium reactions as defined by Appelo and Postma (2005) were also included.

The molal concentrations of aqueous species were used to estimate the ionic contributions to specific conductance (McCleskey and others, 2012). The mineral saturation index (SI) values for various major and trace minerals were used to indicate the potential for mineral dissolution and precipitation. If a mineral phase is undersaturated in groundwater $(\mathrm{SI}<0)$, that mineral phase (if present) has the potential to be dissolved by the groundwater. Likewise, if a mineral is supersaturated in groundwater $(\mathrm{SI}>0)$, that mineral phase feasibly could precipitate, thus limiting the dissolved constituent concentrations. Geochemical modeling with PHREEQC was used to evaluate processes that could feasibly produce the observed concentrations of constituents in the groundwater samples (Parkhurst and Appelo, 2013). A series forward reaction model was developed that simulated the progressive addition of calcite, road-deicing salt, or brine to the dilute background water in order to illustrate the general trends in concentrations of major and minor ions. The chemical compositions indicated by the mass-transfer models were then plotted relative to the amount of solid reactant or brine added to the groundwater and also on Piper diagrams and scatter plots showing the changes in $\mathrm{pH}$ or constituent concentration with reaction progress.

\section{Groundwater Quality and Relation to Human-Health Standards}

Analytical results for the 75 groundwater samples collected in Lycoming County are provided in the following sections and compared to EPA drinking-water standards and health advisories (U.S. Environmental Protection Agency, 2012). The EPA has established maximum contaminant levels (MCLs), secondary maximum contaminant levels (SMCLs), and health advisory levels (HALs) for some constituents in drinking water (table 2). MCLs generally are set because elevated concentrations of these constituents may cause adverse health effects. SMCLs generally are set for aesthetic reasons; elevated concentrations of these constituents may impart an undesirable taste or odor to water. These MCLs and SMCLs may be used as a guideline for private well owners but must be followed for public drinking-water supplies. HALs established by the EPA provide information on contaminants that can cause human-health effects. Although HALs are non-enforceable, they are meant to provide technical guidance on health effects, analytical methodologies, and treatment technologies associated with drinking-water contamination.

\section{Physical and Chemical Properties}

Physical and chemical properties discussed in this section include temperature, $\mathrm{DO}, \mathrm{pH}$, alkalinity (ALK), SC, hardness, and turbidity. These properties are unstable and are determined in the field at the time a water sample is collected. ALK titrations were conducted the day of sampling to determine bicarbonate and carbonate ALK as calcium carbonate. Summary statistics for the unstable physical and chemical properties are given in table 3 .

The temperature of the groundwater samples ranged from 10.2 to $17.9^{\circ} \mathrm{C}$, with a median of $13.1^{\circ} \mathrm{C}$. These temperatures generally were less than the daytime air temperatures during sampling, which reflects the generally cool groundwater environment. Dissolved gases and carbonate minerals can dissolve to a greater extent in cool water than in warm water (Hem, 1985).

DO concentrations ranged from 0.18 to $10.3 \mathrm{mg} / \mathrm{L}$; the median concentration was $2.54 \mathrm{mg} / \mathrm{L}$ (table 3 ). Generally, most of the groundwater had DO concentrations that were less than saturation at the sample temperature, indicating the waters had been out of contact with the atmosphere. Low DO concentrations are associated with higher $\mathrm{pH}$ values; 14 of the 20 water samples with a DO concentration $<1 \mathrm{mg} / \mathrm{L}$ had a $\mathrm{pH}$ 
Table 2. Available U.S. Environmental Protection Agency (EPA) maximum contaminant levels (MCLs), secondary maximum contaminant levels (SMCLs), and health advisory levels (HALs) for analyzed constituents (U.S. Environmental Protection Agency, 2012).

[AMCL, alternative maximum contaminant level; mg/L, milligram per liter; $\mu \mathrm{g} / \mathrm{L}$, microgram per liter; $\mathrm{pCi} / \mathrm{L}$, picocuries per liter; --, no MCL, SMCL, or HAL established]

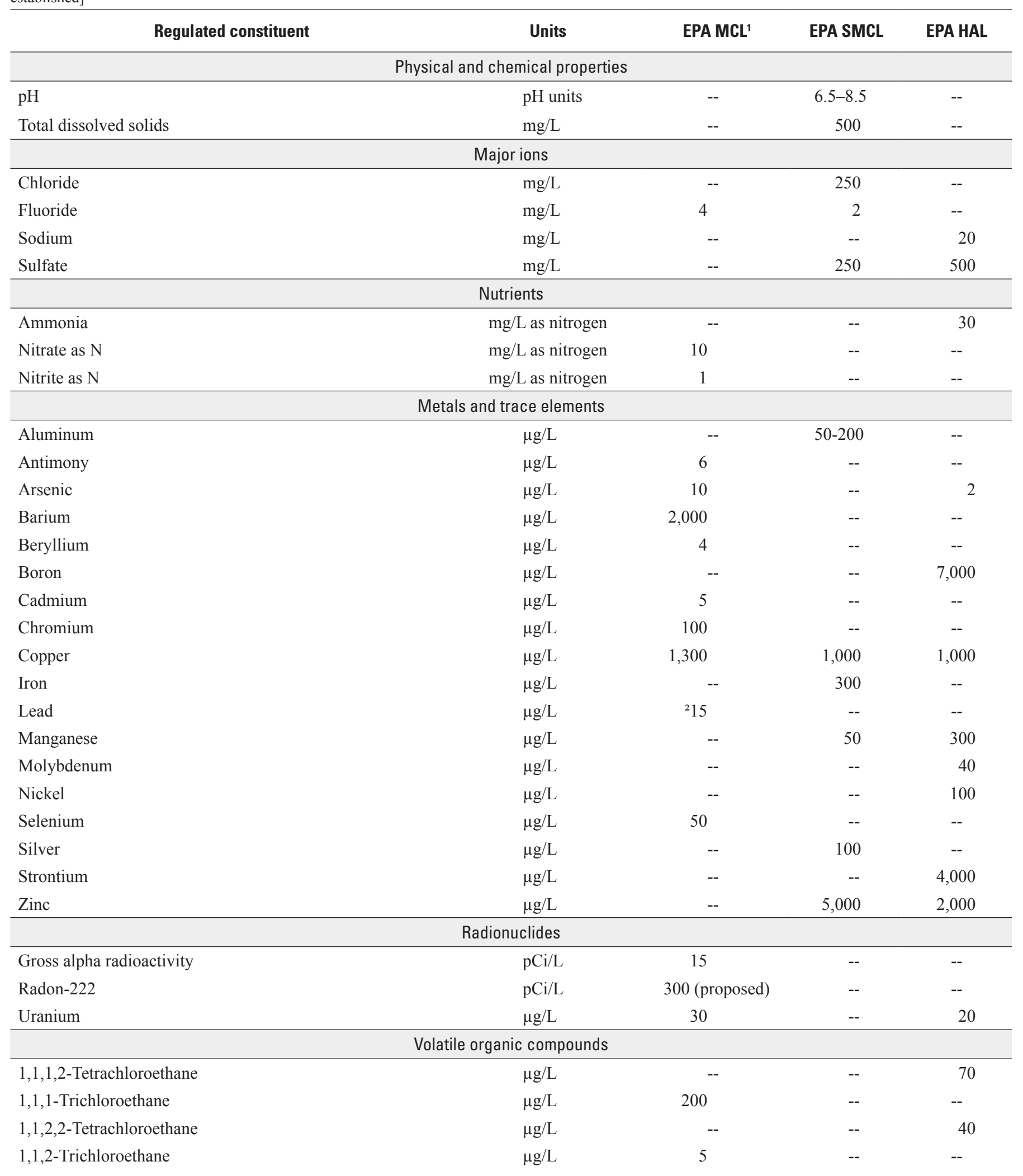


Table 2. Available U.S. Environmental Protection Agency (EPA) maximum contaminant levels (MCLs), secondary maximum contaminant levels (SMCLs), and health advisory levels (HALs) for analyzed constituents (U.S. Environmental Protection Agency, 2012).-Continued

[AMCL, alternative maximum contaminant level; mg/L, milligram per liter; $\mu \mathrm{g} / \mathrm{L}$, microgram per liter; $\mathrm{pCi} / \mathrm{L}$, picocuries per liter; --, no MCL, SMCL, or HAL established]




Table 2. Available U.S. Environmental Protection Agency (EPA) maximum contaminant levels (MCLs), secondary maximum contaminant levels (SMCLs), and health advisory levels (HALs) for analyzed constituents (U.S. Environmental Protection Agency, 2012).-Continued

[AMCL, alternative maximum contaminant level; mg/L, milligram per liter; $\mu \mathrm{g} / \mathrm{L}$, microgram per liter; $\mathrm{pCi} / \mathrm{L}$, picocuries per liter; --, no $\mathrm{MCL}$, SMCL, or $\mathrm{HAL}$ established]

\begin{tabular}{|c|c|c|c|c|}
\hline Regulated constituent & Units & EPA MCL' & EPA SMCL & EPA HAL \\
\hline Total trihalomethanes (TTHMs) & $\mu \mathrm{g} / \mathrm{L}$ & ${ }^{3} 80$ & -- & -- \\
\hline Vinyl Chloride (Chloroethene) & $\mu \mathrm{g} / \mathrm{L}$ & 2 & -- & -- \\
\hline \multicolumn{5}{|c|}{ Glycols and alcohols } \\
\hline Ethylene glycol & $\mathrm{mg} / \mathrm{L}$ & 14 & -- & -- \\
\hline
\end{tabular}

${ }^{1}$ In addition to a proposed MCL, radon-222 has a proposed AMCL of 4,000 pCi/L. States that have multimedia mitigation programs to address radon-222 risks in indoor air would be required to comply with the proposed AMCL, which is higher than the proposed MCL.

${ }^{2}$ Lead in domestic water supplies is regulated by a treatment technnique that requires water purveyors to control the corrosiveness of their water. If more than 10 percent of tap-water samples exceed the action level, the water purveyor must take additional steps. Domestic-supply wells are not regulated.

${ }^{3} 1998$ "Final Rule for Disinfectants and Disinfection By-products" states the total for trihalomethanes (TTHMs) is $80 \mu \mathrm{g} / \mathrm{L}$.

Table 3. Minimum, median, and maximum of well characteristics, physical and chemical properties, major ions, nutrients, and bacteria determined in the laboratory for water samples collected from 75 wells in Lycoming County, Pennsylvania, June-August 2014. Laboratory analysis for dissolved concentrations in filtered samples done by U.S. Geological Survey National Water Quality Laboratory, and laboratory analysis for total concentrations in unfiltered samples done by Seewald Laboratories Incorporated.

$\left[{ }^{\circ} \mathrm{C}\right.$, degrees Celsius; $\mathrm{mg} / \mathrm{L}$, milligram per liter; $\mu \mathrm{S} / \mathrm{cm}$, microsiemen per centimeter; MPN/100mL, most probable number per 100 milliters; <, less than; --, not applicable; EPA, U.S. Environmental Protection Agency; MCL, maximum contaminant level; SMCL, secondary maximum contaminant level; HAL, health advisory level]

\begin{tabular}{|c|c|c|c|c|c|c|c|c|c|}
\hline $\begin{array}{l}\text { Well characteristics and physi- } \\
\text { cal and chemical properties }\end{array}$ & Units & $\begin{array}{l}\text { Number } \\
\text { (percent) } \\
\text { above } \\
\text { reporting } \\
\text { level }\end{array}$ & Minimum & Median & Maximum & $\begin{array}{l}\text { Number } \\
\text { (percent) } \\
\text { exceeding } \\
\text { standard }\end{array}$ & $\begin{array}{l}\text { EPA } \\
\text { MCL }\end{array}$ & $\begin{array}{c}\text { EPA } \\
\text { SMCL }\end{array}$ & $\begin{array}{l}\text { EPA } \\
\text { HAL }\end{array}$ \\
\hline \multicolumn{10}{|c|}{ Well characteristics } \\
\hline Well depth & feet & 75 & 40 & 225 & 620 & -- & -- & -- & -- \\
\hline Water temperature & ${ }^{\circ} \mathrm{C}$ & $75(100)$ & 10.2 & 13.1 & 17.9 & -- & -- & -- & -- \\
\hline Dissolved oxygen & $\mathrm{mg} / \mathrm{L}$ & $75(100)$ & 0.18 & 2.54 & 10.3 & -- & -- & -- & -- \\
\hline Alkalinity (dissolved) & $\begin{array}{l}\mathrm{mg} / \mathrm{L} \text { as calcium } \\
\text { carbonate }\end{array}$ & $75(100)$ & 7.1 & 85.9 & 331 & -- & -- & -- & -- \\
\hline Turbidity & $\begin{array}{l}\text { Nephelometric Tur- } \\
\text { bidity Ratio Units }\end{array}$ & $75(100)$ & 0.13 & 1.12 & 180 & -- & -- & -- & -- \\
\hline \multicolumn{10}{|c|}{ Laboratory analyses } \\
\hline Specific conductance, laboratory & $\mu \mathrm{S} / \mathrm{cm}$ at $25^{\circ} \mathrm{C}$ & $75(100)$ & 19.5 & 217 & 3,120 & -- & -- & -- & -- \\
\hline $\mathrm{pH}$, laboratory & $\mathrm{pH}$ units & $75(100)$ & 5.79 & 7.78 & 9.3 & $25(33)$ & -- & $6.5-8.5$ & -- \\
\hline
\end{tabular}


Table 3. Minimum, median, and maximum of well characteristics, physical and chemical properties, major ions, nutrients, and bacteria determined in the laboratory for water samples collected from 75 wells in Lycoming County, Pennsylvania, June-August 2014. Laboratory analysis for dissolved concentrations in filtered samples done by U.S. Geological Survey National Water Quality Laboratory, and laboratory analysis for total concentrations in unfiltered samples done by Seewald Laboratories Incorporated.—Continued

$\left[{ }^{\circ} \mathrm{C}\right.$, degrees Celsius; $\mathrm{mg} / \mathrm{L}$, milligram per liter; $\mu \mathrm{S} / \mathrm{cm}$, microsiemen per centimeter; MPN/100mL, most probable number per 100 milliters; <, less than; --, not applicable; EPA, U.S. Environmental Protection Agency; MCL, maximum contaminant level; SMCL, secondary maximum contaminant level; HAL, health advisory level]

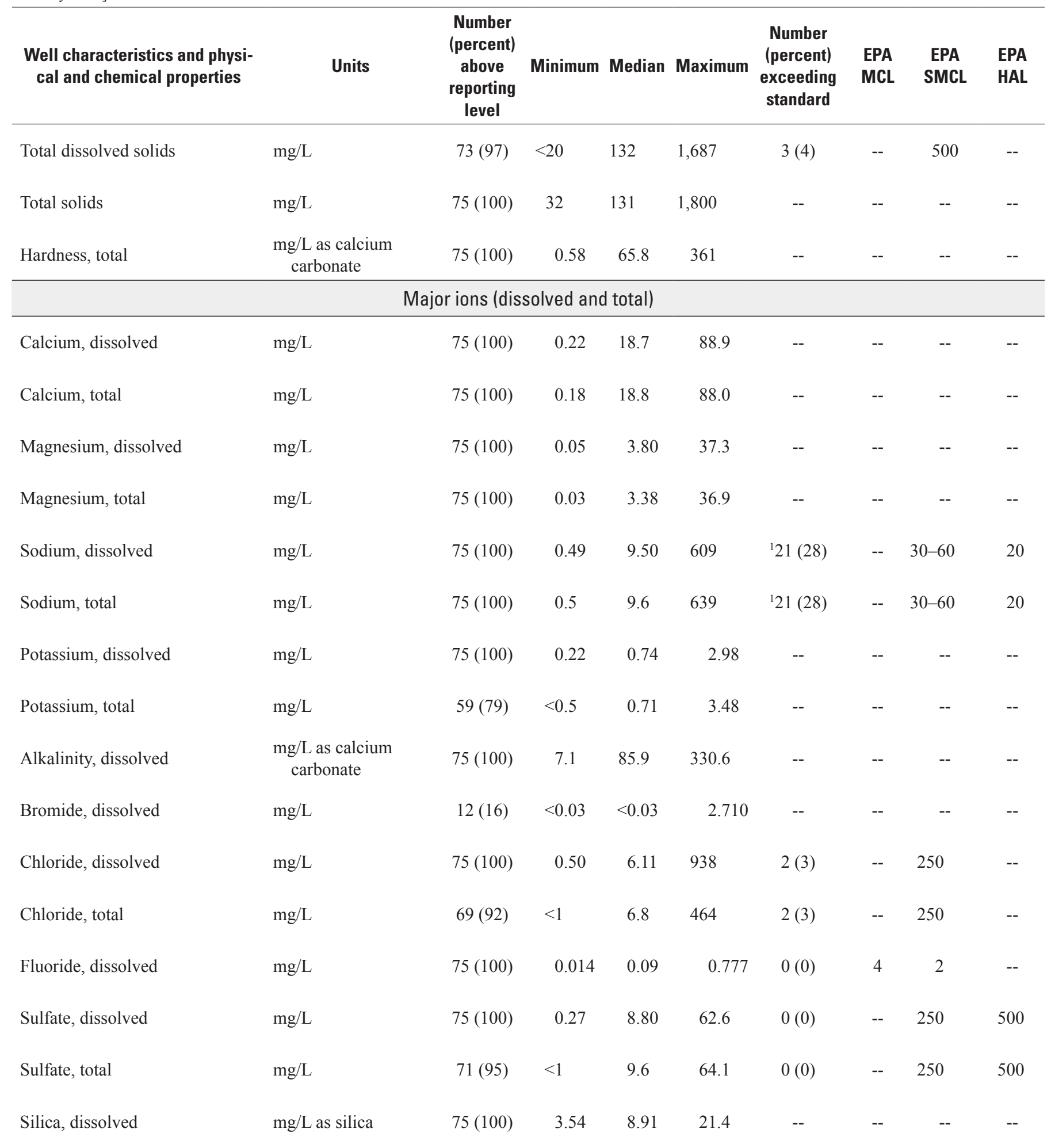


Table 3. Minimum, median, and maximum of well characteristics, physical and chemical properties, major ions, nutrients, and bacteria determined in the laboratory for water samples collected from 75 wells in Lycoming County, Pennsylvania, June-August 2014. Laboratory analysis for dissolved concentrations in filtered samples done by U.S. Geological Survey National Water Quality Laboratory, and laboratory analysis for total concentrations in unfiltered samples done by Seewald Laboratories Incorporated.-Continued

$\left[{ }^{\circ} \mathrm{C}\right.$, degrees Celsius; mg/L, milligram per liter; $\mu \mathrm{S} / \mathrm{cm}$, microsiemen per centimeter; MPN/100mL, most probable number per 100 milliters; <, less than; --, not applicable; EPA, U.S. Environmental Protection Agency; MCL, maximum contaminant level; SMCL, secondary maximum contaminant level; HAL, health advisory level]

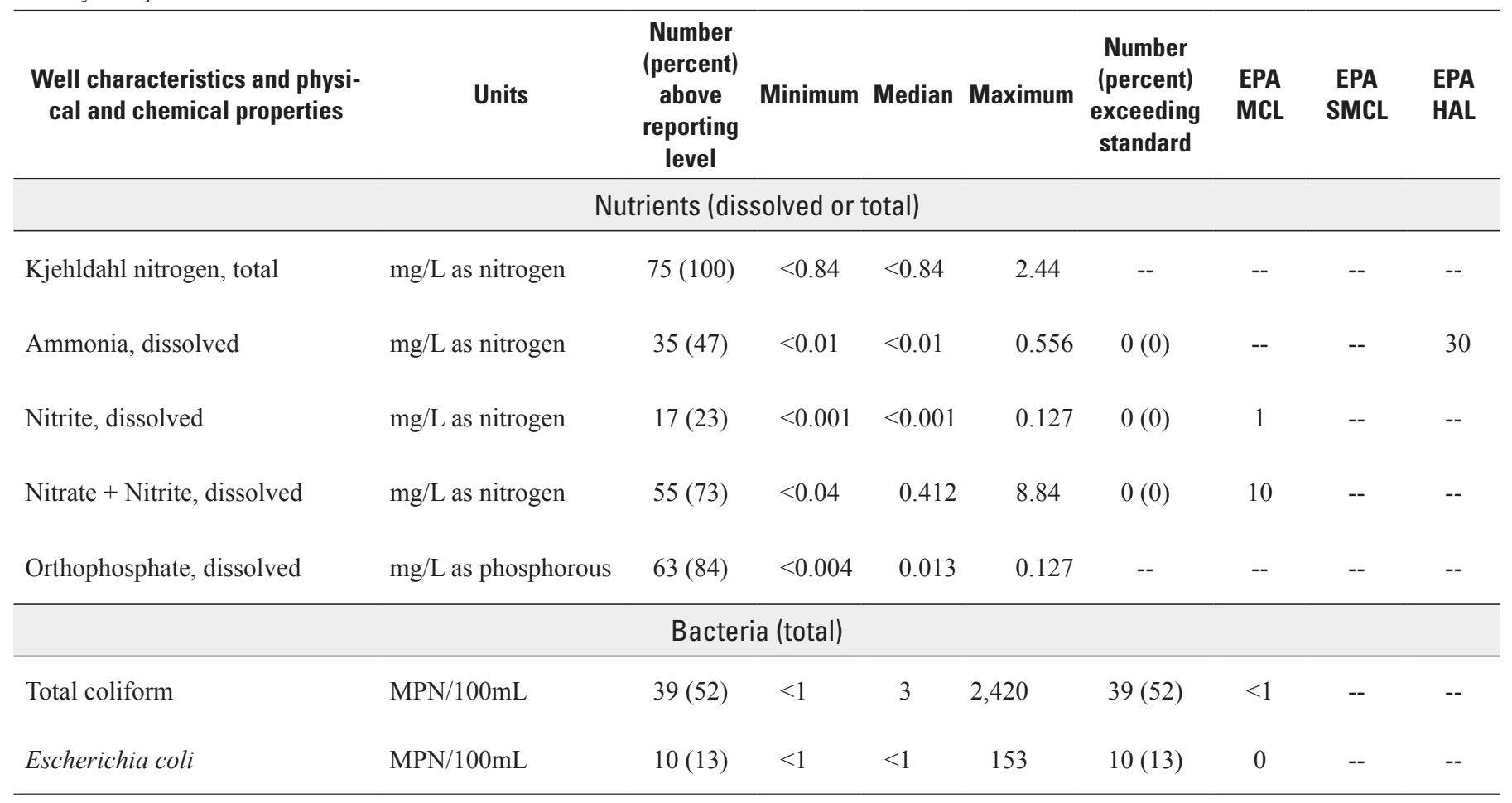

121 samples (28 percent) exceed HAL of $20 \mathrm{mg} / \mathrm{L}$ and 6 samples (8 percent) exceed upper SMCL limit of $60 \mathrm{mg} / \mathrm{L}$.

greater than 7.5. Low DO concentrations are related to chemical or biochemical reactions that consume oxygen and may be associated with reducing conditions that promote the release of iron, manganese, and associated metals to solution. The chemical reactions that consume oxygen generally involve organic carbon that can be naturally present in soil or aquifer materials or can be introduced from industrial, agricultural, or domestic wastes. Of the 75 well samples in this study, 19 percent were classified as "anoxic" (DO less than or equal to [ $\leq] 0.5 \mathrm{mg} / \mathrm{L}$ ), 68 percent as "oxic" ( $\mathrm{DO}>0.5 \mathrm{mg} / \mathrm{L})$, and 13 percent as "mixed" (DO $>0.5 \mathrm{mg} / \mathrm{L}$ with manganese $>0.05 \mathrm{mg} / \mathrm{L}$ or iron $>0.1 \mathrm{mg} / \mathrm{L}$ ) based on criteria of McMahon and Chapelle (2008). Only 4 of the 14 samples classified as anoxic had chemical characteristics consistent with reducing conditions for iron and manganese oxides as defined by McMahon and Chapelle (2008); DO $\leq 0.5 \mathrm{mg} / \mathrm{L}$; nitrate $<0.5 \mathrm{mg} / \mathrm{L}$, manganese $>0.05 \mathrm{mg} / \mathrm{L}$, iron $>0.1 \mathrm{mg} / \mathrm{L}$, and sulfate $>0.5 \mathrm{mg} / \mathrm{L}$; none were identified with more strongly reducing conditions necessary for sulfate reduction or methanogenesis.

The $\mathrm{pH}$ is a measure of acidity and is related to the potential corrosivity of the water and its potential to leach metals, such as lead and copper from pipes and plumbing. The standard $\mathrm{pH}$ scale is 0 to 14 , with 7 being neutral. Generally, $\mathrm{pH}$ values of 6.5 to 7.5 are considered near neutral, values $<6.5$ are considered acidic, and values $>7.5$ are considered basic or alkaline. The $\mathrm{pH}$ of water samples collected in Lycoming County ranged from 5.3 to 9.15 ; the median $\mathrm{pH}$ was 7.33 . The $\mathrm{pH}$ of 25 of the 75 samples ( 33 percent) was outside the EPA SMCL range of 6.5 to 8.5 (U.S. Environmental Protection Agency, 2012). Seventeen samples had a pH less than 6.5, and eight samples had a pH greater than 8.5 (table 3). Generally, the $\mathrm{pH}$ varied widely within and among the lithologic classes; median $\mathrm{pH}$ values were greatest for shale (7.69), least for sandstone (7.01), and intermediate for carbonate (7.33) and siltstone (7.18) classes (fig. 5).

The ALK of a solution indicates its capacity to neutralize acid and commonly results from dissolved carbonate and bicarbonate ions (Hem, 1985, p. 106). ALK, also referred to as the acid neutralizing capacity, is related to the $\mathrm{pH}$ of a water sample. In general, water samples with a higher $\mathrm{pH}$ have a higher ALK. ALK ranged from 7.1 to $331 \mathrm{mg} / \mathrm{L}$ as calcium carbonate; the median concentration was $85.9 \mathrm{mg} / \mathrm{L}$ (table 3 ). The estimated concentration of ALK to achieve ionic balance ranged from 9.8 to $300 \mathrm{mg} / \mathrm{L}$ as calcium carbonate (fig. 4). The highest alkalinities were from carbonate lithologies and the lowest were from sandstone. 


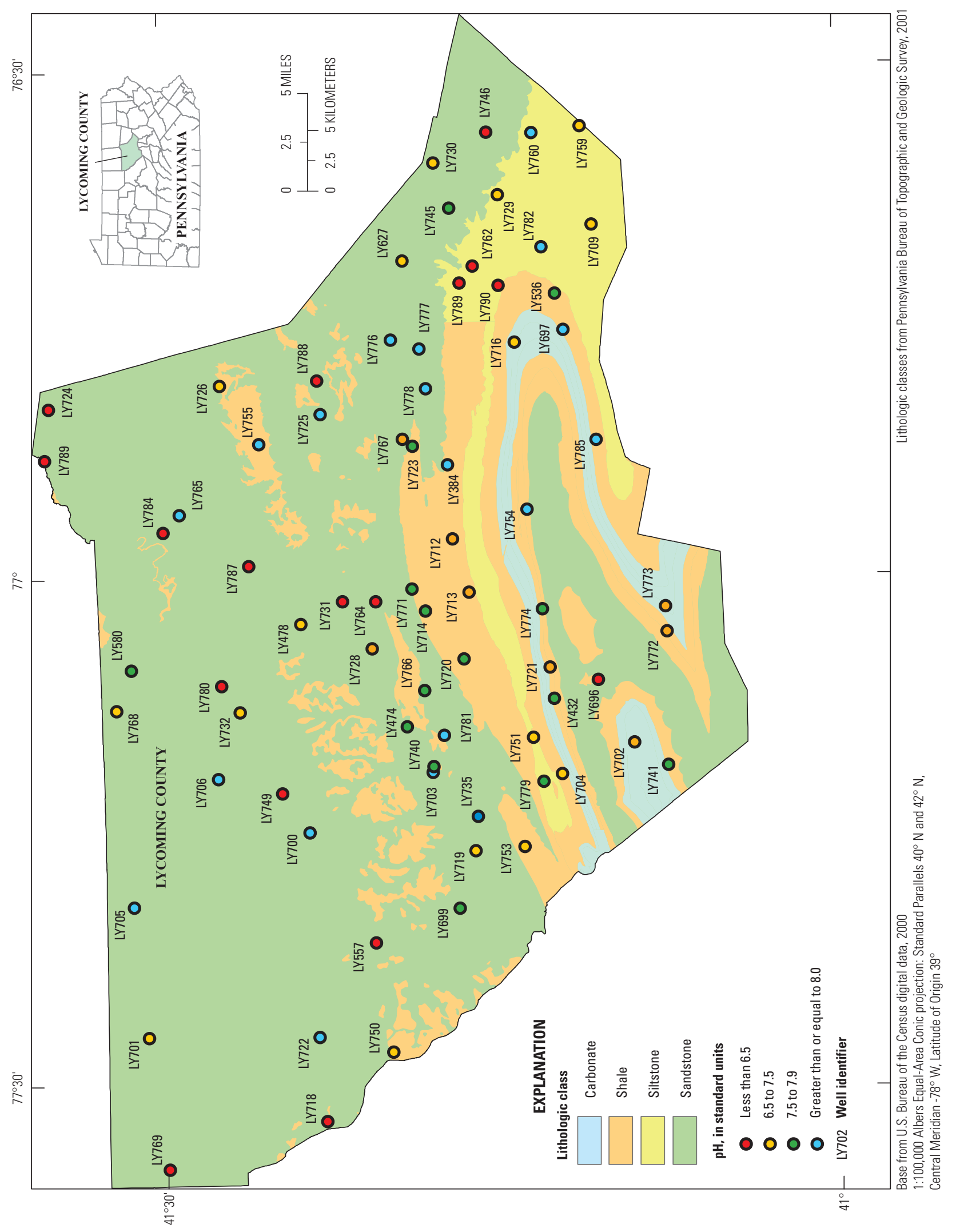


Hardness of the 75 well-water samples (computed as the sum of calcium, in $\mathrm{mg} / \mathrm{L}$, multiplied by a factor of 2.5 plus magnesium, in $\mathrm{mg} / \mathrm{L}$, multiplied by a factor of 4.1) ranged from $<0.58$ to $361 \mathrm{mg} / \mathrm{L}$ as calcium carbonate, with a median value of $65.8 \mathrm{mg} / \mathrm{L}$ as calcium carbonate. Hardness generally results from the dissolution of calcium- and magnesiumbearing minerals, such as calcite and dolomite, that are commonly associated with limestone and other calcareous sedimentary rocks. Hard water decreases lathering of soap and increases accumulation of mineral deposits in plumbing and cooking utensils. Using a common hardness classification (Dufor and Becker, 1964), the measured values indicate that 34 (45 percent) of the 75 water samples are soft $(<60 \mathrm{mg} / \mathrm{L}$ as calcium carbonate); 29 samples (39 percent) are moderately hard (61 to $120 \mathrm{mg} / \mathrm{L}$ as calcium carbonate); 7 samples (9 percent) are hard (121 to $180 \mathrm{mg} / \mathrm{L}$ as calcium carbonate); and 5 samples ( 7 percent) are classified as very hard (greater than $180 \mathrm{mg} / \mathrm{L}$ as calcium carbonate). Median hardness values were $329,86,73$, and $44 \mathrm{mg} / \mathrm{L}$ as calcium carbonate for carbonate, shale, siltstone, and sandstone lithologies, respectively. Hardness varied with $\mathrm{pH}$, with hardness generally greatest at near-neutral $\mathrm{pH}$ values (6.5 to 7.5). Water samples with low $\mathrm{pH}(<6.5)$ and very high $\mathrm{pH}(>8.0)$ typically had hardness $<60 \mathrm{mg} / \mathrm{L}$ and were soft. The high-pH waters with low hardness typically have elevated sodium, which results from natural water-softening processes, described later in "Relations Among Constituents in Groundwater" section. There are no health-related standards established specifically for hardness in drinking water.

Hard water has greater potential than soft water to form scale or encrustations on plumbing and fixtures. Water resources engineers commonly identify the potential for encrustation or corrosion on the basis of the Langelier Index (LI), which provides an indication for the potential for lead and copper to enter water supplies from pipes and plumbing (Snoeyink and Jenkins, 1981). The LI, which is the difference between the measured $\mathrm{pH}$ and the $\mathrm{pH}$ at equilibrium with calcium carbonate, is equal in value to the calcite saturation index $\left(\mathrm{SI}_{\mathrm{CAL}}\right)$, evaluated in more detail later. If the $\mathrm{LI}$ or $\mathrm{SI}_{\mathrm{CAL}}$ is positive, the $\mathrm{pH}$ is greater than that at equilibrium with calcium carbonate and the water will tend to deposit calcium carbonate coating or scale that can insulate pipes, boilers and other components of a system from contact with water; however, if negative, then the water is undersaturated with calcium carbonate and will tend to be corrosive in the distribution system. The optimum condition is when the $\mathrm{LI}$ or $\mathrm{SI}_{\mathrm{CAL}}$ is close to zero, whereby the water will be neither strongly corrosive nor scale forming. For the 75 groundwater samples, $\mathrm{SI}_{\mathrm{CAL}}$ ranged from -5.0 to 0.2 . Of the 75 samples, 31 (41 percent) had LI values that were $<-1$, indicating potentially strongly corrosive characteristics; the remaining samples would be considered neither strongly corrosive nor scale forming. Most samples characterized as strongly corrosive had $\mathrm{pH}$ values $<7$ and hardness $<90 \mathrm{mg} / \mathrm{L}$ as calcium carbonate.

Specific conductance (SC) is a gross measure of the ability of ions in water to conduct an electrical current and is expressed in units of microsiemens per centimeter. The higher the value for $\mathrm{SC}$, the higher the concentrations of dissolved solids and associated ions in the water (fig. 4). The field-measured SC for the 75 groundwater samples ranged from 24.7 to 3,193 microsiemens per centimeter at $25^{\circ} \mathrm{C}(\mu \mathrm{S} / \mathrm{cm}$; fig. $4 F)$; the median specific conductance was $214 \mu \mathrm{S} / \mathrm{cm}$ (table 3 ). Values were similar for the laboratory-measured SC (fig. 4 and table 3). Explanations for ionic source of elevated SC are provided later.

Turbidity is a measure of the amount of solid particles suspended in water that block the transmission of light through the sample. Turbidity is expressed in Nephelometric Turbidity Ratio Units (NTRU), which quantify the degree to which light is scattered by solid particles suspended in water. When the NTRU is high, the turbidity of the water increases. Turbidity concentrations ranged from 0.13 to $180 \mathrm{NTRU}$; the median concentration was 1.12 NTRU (table 3). In general, samples with high turbidity could be expected to have total concentrations of constituents that include contributions from suspended particles, in addition to the dissolved concentration.

\section{Major lons}

Major ions dissolved from soil and rock contribute most of the naturally present dissolved solutes in groundwater. The remainder comes mostly from constituents dissolved in precipitation. Anthropogenic sources, such as road-deicing chemicals, can also contribute to major ion concentrations. Major ions generally account for most of the dissolved constituents in groundwater and consist of positively charged cations (calcium, magnesium, sodium, and potassium) balanced by negatively charged anions (bicarbonate, chloride, nitrate, sulfate, and fluoride). Silica is a major constituent that is commonly an uncharged ion. Major ions were analyzed for filtered and unfiltered samples to represent both dissolved and total concentrations. Drinking-water standards have been established for only a few major ions and are commonly either a SMCL or HAL, both of which are recommended rather than regulatory standards. Of the major ions, only fluoride has an established MCL in drinking water because excessive consumption of fluoride can damage bone tissue. Summary statistics for major ions are given in table 3. Major ions, in order of decreasing median dissolved concentration, were calcium, sodium, silica, sulfate, chloride, magnesium, potassium, fluoride, and bromide.

Total dissolved solids (TDS) are a measurement of the total solute in water and are measured by evaporating the water and weighing the residue. The TDS concentration ranged from $<20$ to $1,687 \mathrm{mg} / \mathrm{L}$; the median concentration was $132 \mathrm{mg} / \mathrm{L}$. Out of 75 samples, 3 samples (4 percent) exceeded $500 \mathrm{mg} / \mathrm{L}$, which is the EPA SMCL for TDS in drinking water. The three samples with elevated TDS also had the highest concentrations of sodium and chloride out of all 75 samples and were from the Catskill and Lock Haven Formations (fig. 2). Elevated sodium and chloride concentrations could be caused by connate water in the formations and a zone 
of restricted groundwater flow that limits flushing by fresh recharge, mixing of saline and freshwater, or by the introduction of salt from near-surface contaminant sources such as road-deicing salts, water softener additives, effluent from septic systems, or animal waste (Mullaney and others, 2009).

Dissolved concentrations of sodium ranged from 0.49 to $609 \mathrm{mg} / \mathrm{L}$; the median concentration was $9.5 \mathrm{mg} / \mathrm{L}$. The EPA has issued a taste threshold for sodium in public water supplies that recommends reducing sodium concentrations to between 30 and $60 \mathrm{mg} / \mathrm{L}$ (U.S. Environmental Protection Agency, 2003). This recommendation is a guideline that is not federally enforceable. The EPA HAL for sodium in drinking water is $20 \mathrm{mg} / \mathrm{L}$. Out of 75 samples, 21 samples ( 28 percent) exceeded the HAL of $20 \mathrm{mg} / \mathrm{L}$, whereas 6 samples (8 percent) exceeded the taste threshold upper limit of $60 \mathrm{mg} / \mathrm{L}$. Salt used for food, road deicing, and other applications consists of sodium chloride. Thus, high concentrations of sodium and chloride may result from the addition of sodium chloride to the groundwater and may be related to land use as well as the lithology. Dissolved concentrations of chloride ranged from 0.5 to $938 \mathrm{mg} / \mathrm{L}$; the median concentration was $6.11 \mathrm{mg} / \mathrm{L}$ (fig. 6). Out of 75 samples, 2 samples (3 percent) exceeded the EPA SMCL of $250 \mathrm{mg} / \mathrm{L}$ for chloride in drinking water.

\section{Nutrients}

Nutrients include nitrogen and phosphorous species. Nitrogen compounds in water include nitrate as nitrogen, nitrite, and ammonia, whereas phosphorus is present mainly as orthophosphate. Nutrients are essential for plant growth; however, the presence of elevated nutrient concentrations generally is an indicator of anthropogenic sources, which might include fertilizers, storm runoff, animal wastes, and effluent from septic systems. Summary statistics for nutrients are given in table 3 . Nitrate is the most prevalent nitrogen species in oxic groundwater, but all nitrate concentrations were still less than the EPA MCL of $10 \mathrm{mg} / \mathrm{L}$ for nitrate as nitrogen (table 3). Excessive nitrate in drinking water causes a health threat, especially in infants, because it disrupts oxygen flow in the blood. Infants below the age of 6 months who drink water containing nitrate in excess of the MCL could become seriously ill, develop symptoms including shortness of breath and blue-baby syndrome, and may die if left untreated. Because concentrations of nitrite are so low, nitrate plus nitrite concentrations essentially represent nitrate concentrations. The concentration of nitrate ranged from $<0.04$ to $8.84 \mathrm{mg} / \mathrm{L}$ as nitrogen; the median concentration was $0.412 \mathrm{mg} / \mathrm{L}$ as nitrogen. The concentration of orthophosphate ranged from $<0.004$ to $0.127 \mathrm{mg} / \mathrm{L}$ with a median of $0.013 \mathrm{mg} / \mathrm{L}$.

\section{Bacteria}

All samples were analyzed for total coliform and Escherichia coli (E. coli) to help to determine the associated humanhealth risk of potentially pathogenic (disease-causing) waterborne microorganisms. Coliform bacteria are ubiquitous in the environment and are not always pathogenic. Some strains of E. coli, such as O157:H7, can cause severe illness, and the presence of $E$. coli may indicate general fecal contamination because of the strong association of $E$. coli with the intestines of warm-blooded animals. Any detection of $E$. coli in public drinking-water supplies is considered cause for concern and a violation of health standards (U.S. Environmental Protection Agency, 2001), and these EPA criteria can be used to provide a reference point for domestic wells.

Total coliform bacteria were detected in 39 of the 75 groundwater samples (52 percent) (table 3 ). Total coliform concentrations ranged from $<1$ colonies per 100 milliliters (reported as most probable number per 100 milliliters [MPN/100mL]) to $2,420 \mathrm{MPN} / 100 \mathrm{~mL}$. Of the 39 samples that had total coliform bacteria, 10 samples had detectable E. coli, with concentrations ranging from 3 to $153 \mathrm{MPN} / 100 \mathrm{~mL}$.

\section{Metals and Trace Elements}

Metals and other trace elements are typically present in concentrations $<1 \mathrm{mg} / \mathrm{L}$ in natural waters (Hem, 1985). Most metals and trace elements in groundwater are leached from soil or dissolved from underlying bedrock by groundwater, but some are present in precipitation. Summary statistics for metals and trace elements are listed in table 4.

The EPA has established MCLs, SMCLs, and HALs as the concentration of specific metals and trace elements in drinking water (tables 2 and 4). Samples from 9 wells (12 percent) exceeded the EPA MCL for arsenic, whereas 20 samples (27 percent) exceeded the SMCL for total iron or total manganese. Two samples ( 3 percent) exceeded $300 \mu \mathrm{g} / \mathrm{L}$, which is the EPA HAL for total manganese (U.S. Environmental Protection Agency, 2012). If considering the dissolved concentration, the number of samples exceeding these criteria decreases (table 4). As mentioned previously, the replicate sample collected from LY789 had a copper concentration $36.95 \mu \mathrm{g} / \mathrm{L}$ greater than the environmental sample concentration (100-percent increase) and a zinc concentration $5.743 \mu \mathrm{g} / \mathrm{L}$ greater than the environmental sample concentration (272-percent increase). Out of the 75 wells sampled, if the highest resulting concentrations of copper and zinc were increased by 100 percent and 272 percent, respectively, the highest copper concentration would be $289.4 \mu \mathrm{g} / \mathrm{L}$ and the 


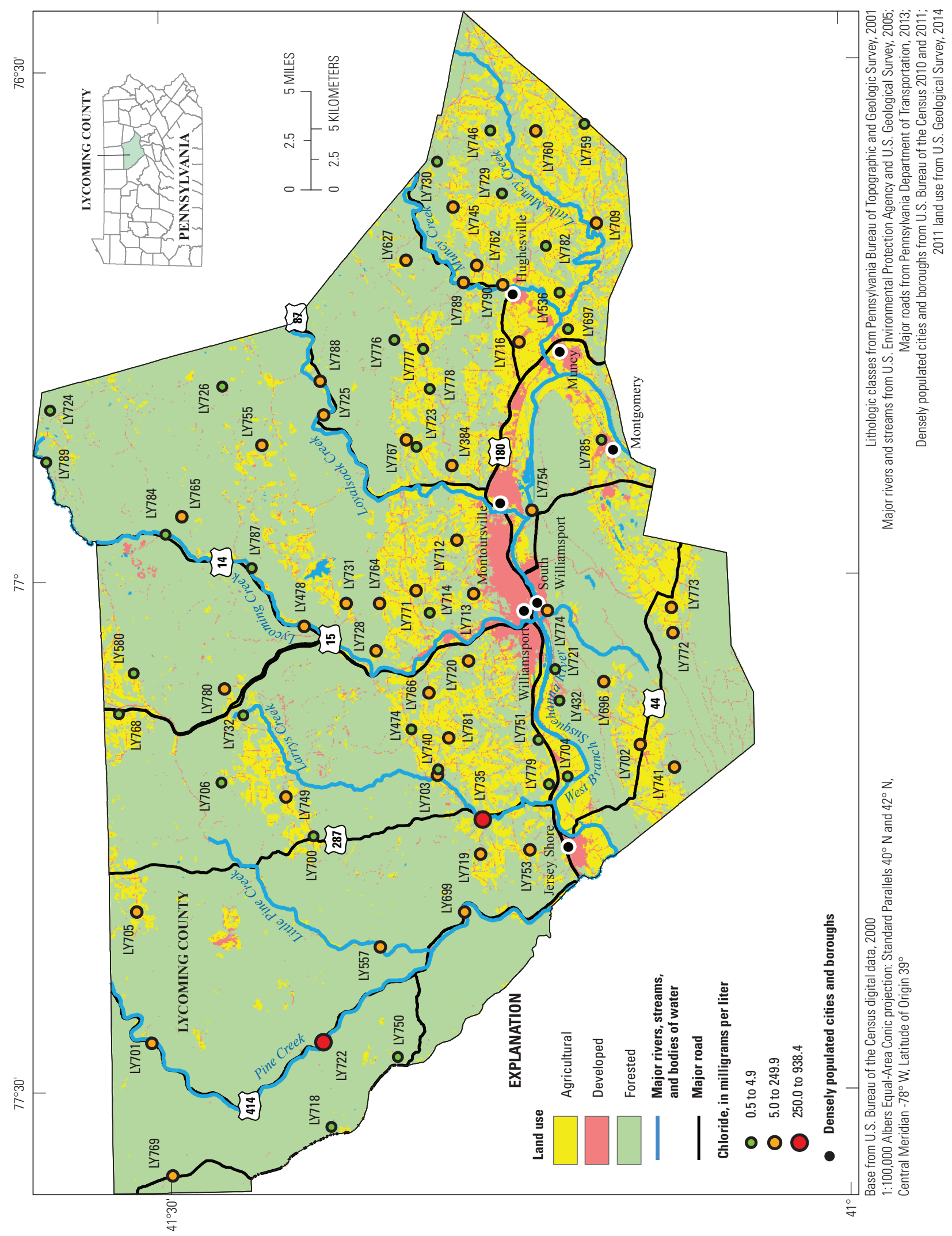


Table 4. Minimum, median, and maximum concentrations of metals and trace elements for water samples collected from 75 wells in Lycoming County, Pennsylvania, June-August 2014. Laboratory analysis for dissolved concentrations in filtered samples done by U.S. Geological Survey National Water Quality Laboratory, and laboratory analysis for total concentrations in unfiltered samples done by Seewald Laboratories Incorporated.

$[\mu \mathrm{g} / \mathrm{L}$, microgram per liter; <, less than; --, no data or not applicable; EPA, U.S. Environmental Protection Agency; MCL, maximum contaminant level; SMCL, secondary maximum level; HAL, health advisory level]

\begin{tabular}{|c|c|c|c|c|c|c|c|c|c|}
\hline $\begin{array}{l}\text { Metals and trace } \\
\text { elements }\end{array}$ & Units & $\begin{array}{c}\text { Number } \\
\text { (percent) } \\
\text { above } \\
\text { reporting } \\
\text { level }\end{array}$ & Minimum & Median & Maximum & $\begin{array}{l}\text { Number } \\
\text { (percent) } \\
\text { exceeding } \\
\text { standard }\end{array}$ & $\begin{array}{l}\text { EPA } \\
\text { MCL }\end{array}$ & $\begin{array}{l}\text { EPA } \\
\text { SMCL }\end{array}$ & $\begin{array}{l}\text { EPA } \\
\text { HAL }\end{array}$ \\
\hline \multicolumn{10}{|c|}{ Dissolved constituent (filtered samples) } \\
\hline Antimony & $\mu \mathrm{g} / \mathrm{L}$ & $36(48)$ & $<0.027$ & $<0.027$ & 1.69 & $0(0)$ & 6 & -- & -- \\
\hline Arsenic & $\mu \mathrm{g} / \mathrm{L}$ & $62(83)$ & $<0.10$ & 0.85 & 23.6 & $19(12)$ & 10 & -- & 2 \\
\hline Beryllium & $\mu \mathrm{g} / \mathrm{L}$ & $6(8)$ & $<0.020$ & $<0.020$ & 0.09 & $0(0)$ & 4 & -- & -- \\
\hline Boron & $\mu \mathrm{g} / \mathrm{L}$ & $68(91)$ & $<5$ & 16.7 & 561 & $0(0)$ & -- & -- & 7,000 \\
\hline Cobalt & $\mu \mathrm{g} / \mathrm{L}$ & $27(36)$ & $<0.050$ & $<0.050$ & 5.82 & -- & -- & -- & -- \\
\hline Copper & $\mu \mathrm{g} / \mathrm{L}$ & $53(71)$ & $<0.80$ & 2.48 & 145 & $0(0)$ & 1,300 & -- & 1,000 \\
\hline Lead, dissolved & $\mu \mathrm{g} / \mathrm{L}$ & $58(77)$ & $<0.040$ & 0.16 & 2.03 & $0(0)$ & 15 & -- & -- \\
\hline Lithium & $\mu \mathrm{g} / \mathrm{L}$ & $75(100)$ & 0.409 & 10.7 & 523 & -- & -- & -- & -- \\
\hline Molybdenum & $\mu \mathrm{g} / \mathrm{L}$ & $64(85)$ & $<0.05$ & 0.316 & 6.52 & $0(0)$ & -- & -- & 40 \\
\hline Nickel & $\mu \mathrm{g} / \mathrm{L}$ & $55(73)$ & $<0.20$ & 0.376 & 7.25 & $0(0)$ & -- & -- & 100 \\
\hline Selenium & $\mu \mathrm{g} / \mathrm{L}$ & $49(65)$ & $<0.05$ & 0.088 & 6.13 & $0(0)$ & 50 & -- & -- \\
\hline \multicolumn{10}{|c|}{ Dissolved and total constituents (filtered and unfiltered samples) } \\
\hline Iron, dissolved & $\mu \mathrm{g} / \mathrm{L}$ & $48(64)$ & $<4.0$ & 7.16 & 8,340 & $3(4)$ & -- & 300 & -- \\
\hline Iron, total & $\mu \mathrm{g} / \mathrm{L}$ & $59(79)$ & $<10.0$ & 71.4 & 13,900 & $20(27)$ & -- & 300 & -- \\
\hline Manganese, dissolved & $\mu \mathrm{g} / \mathrm{L}$ & $56(75)$ & $<0.40$ & 2.08 & 1,100 & ${ }^{2} 12(16)$ & -- & 50 & 300 \\
\hline Manganese, total & $\mu \mathrm{g} / \mathrm{L}$ & $64(85)$ & $<0.50$ & 14.6 & 761 & ${ }^{3} 20(27)$ & -- & 50 & 300 \\
\hline Strontium, dissolved & $\mu \mathrm{g} / \mathrm{L}$ & $75(100)$ & 4.919 & 232 & 3,872 & $0(0)$ & -- & -- & 4,000 \\
\hline Strontium, total & $\mu \mathrm{g} / \mathrm{L}$ & $73(97)$ & $<10.0$ & 240 & 4 & 1(1) & -- & -- & 4,000 \\
\hline
\end{tabular}

${ }^{1} 4$ samples exceed the MCL of $10 \mu \mathrm{g} / \mathrm{L}$ and 23 samples (31 percent) exceed the HAL of $2 \mu \mathrm{g} / \mathrm{L}$ for arsenic.

${ }^{2} 12$ samples (16 percent) exceed the SMCL level of $50 \mu \mathrm{g} / \mathrm{L}$ and 1 (1 percent) sample exceeds the HAL of $300 \mu \mathrm{g} / \mathrm{L}$ for dissolved manganese.

${ }^{3} 20$ samples (27 percent) exceed the SMCL level of $50 \mu \mathrm{g} / \mathrm{L}$ and 2 (3 percent) samples exceed the HAL of $300 \mu \mathrm{g} / \mathrm{L}$ for total manganese. 
highest zinc concentration would be $1,362.6 \mu \mathrm{g} / \mathrm{L}$, which are less than established drinking-water standards.

Arsenic concentrations ranged from $<0.10$ to $23.6 \mu \mathrm{g} / \mathrm{L}$ with a median concentration of $0.85 \mu \mathrm{g} / \mathrm{L}$ (fig. 7). Arsenic concentration is related to $\mathrm{pH}$ (fig. 8). All nine samples with arsenic concentrations exceeding the EPA MCL of $10 \mu \mathrm{g} / \mathrm{L}$ had $\mathrm{pH}$ greater than 7.0; six had $\mathrm{pH}$ greater than 8.0. Arsenate and arsenite, which are the predominant forms of arsenic in groundwater, tend to adsorb to a variety of aquifer materials, including iron oxides, aluminum oxides, and clay minerals, at mildly acidic to neutral $\mathrm{pH}$ but not at alkaline $\mathrm{pH}$ conditions (Dzombak and Morel, 1990; Smedley and Kinniburgh, 2002). Furthermore, under strongly acidic or reducing conditions, oxide minerals may become unstable and dissolve, releasing arsenic to the solution. More detailed explanation of the effects of $\mathrm{pH}$ on sorption processes and the possible relations between redox state and arsenic concentration are presented in a later section of this report. Possible health effects associated with ingestion of drinking water with arsenic in excess of the MCL for many years include skin damage, circulatory system problems, and increased cancer risk.

Water samples with a $\mathrm{pH}$ of 8.0 or greater also had the highest concentrations of boron, bromide, lithium, fluoride, and sodium (figs. 9, 10). In addition, water samples with a $\mathrm{pH}$ greater than 8.67 had nickel and zinc concentrations less than the detection limit. Generally, the decreased concentrations of trace cations, such as nickel and zinc, with increased $\mathrm{pH}$ may be explained by their strong adsorption at alkaline $\mathrm{pH}$ by iron oxides, whereas the increased concentrations of trace anions, such as arsenic, may result from their desorption at alkaline $\mathrm{pH}$. The increased concentrations of sodium and lithium could result from cation-exchange reactions. The potential effects of ion exchange and other geochemical processes on $\mathrm{pH}$ and associated constituent concentrations are developed more completely in the following sections of this report.

Elevated concentrations of iron and manganese in water may impart a bitter taste and stain laundry and plumbing fixtures with a yellowish or brownish-orange color. Large doses of manganese can cause headaches, whereas long-term heavy exposure may result in nervous-system disorders. Concentrations of total iron ranged from $<10.0$ to $13,900 \mu \mathrm{g} / \mathrm{L}$, with a median of $71.4 \mu \mathrm{g} / \mathrm{L}$; dissolved iron ranged from $<4.0$ to $8,340 \mu \mathrm{g} / \mathrm{L}$, with a median of $7.16 \mu \mathrm{g} / \mathrm{L}$. Concentrations of total manganese ranged from $<0.50$ to $761 \mu \mathrm{g} / \mathrm{L}$, with a median of $14.6 \mu \mathrm{g} / \mathrm{L}$; dissolved manganese ranged from $<0.40$ to $1,100 \mu \mathrm{g} / \mathrm{L}$, with a median of $2.08 \mu \mathrm{g} / \mathrm{L}$. Twenty of these samples (27 percent) exceeded the EPA SMCL of $300 \mu \mathrm{g} / \mathrm{L}$ for total iron; however, only three samples (4 percent) had dissolved iron concentrations greater than $300 \mu \mathrm{g} / \mathrm{L}$. Likewise, 20 samples (27 percent) had total manganese concentrations that exceeded the EPA SMCL of $50 \mu \mathrm{g} / \mathrm{L}$, but only 12 (16 percent) had dissolved manganese concentrations greater than the SMCL. Two samples (3 percent) had total manganese concentrations in excess of the $300 \mu \mathrm{g} / \mathrm{L}$ EPA HAL for manganese (U.S. Environmental Protection Agency, 2012).
Although none of the well-water samples had concentrations of lead or copper in excess of the respective MCL values of 15 and $1,300 \mu \mathrm{g} / \mathrm{L}$, corrosive water, as previously described by the LI or $\mathrm{SI}_{\mathrm{CAL}}<-1$, could acquire metals from lead or copper pipes in the household water system. Long-term exposure to excess copper can cause liver or kidney damage, whereas lead can cause neurological problems, especially in young children. Depending on water treatment, the corrosive characteristics may or may not be mitigated. Sampling at the tap would produce results describing actual concentrations of constituents in the household drinking water and could be used to evaluate the potential effects of water treatment, but this study was designed to evaluate constituent concentrations within the aquifer where the household well is completed, rather than the tap water being expelled within the household.

\section{Radionuclides}

Radionuclides naturally present in rocks and soils may be dissolved or leached into groundwater. Analyses for radioactivity and radionuclides include gross alpha radioactivity, gross beta radioactivity, and dissolved radon-222 (radon gas). Uranium, a radioactive element, also was analyzed in the dissolved form. Summary statistics for radioactive constituents are given in table 5. The EPA has established or proposed MCLs for some of these constituents in drinking water (table 2).

Radioactivity is the release of energy and energetic particles by changes in the structure of certain unstable elements as they break down to form more stable arrangements. Radioactive energy is released as (1) alpha radiation consisting of positively charged helium nuclei, (2) beta radiation consisting of electrons or positrons, and (3) gamma radiation consisting of electromagnetic waves. The most commonly used unit for radioactivity in water is picocuries per liter. One Curie is the activity of 1 gram of radium, which is equal to $3.7 \times 10^{10}$ atomic disintegrations per second. Activity refers to the number of particles emitted by a radionuclide. The rate of decay is proportional to the number of atoms present and inversely proportional to half-life. The half-life is the amount of time it takes for a radioactive element to decay to one-half of its original quantity.

Naturally present radioactivity in groundwater is produced primarily by the radioactive decay of uranium- 238 and thorium-232, which are present in minerals. These isotopes disintegrate in steps emitting either alpha or beta particles and forming a series of radioactive nuclide "daughter" products, mostly short-lived, until a stable lead isotope is produced. The uranium-238 decay series produces the greatest amount of radioactivity in natural groundwater (Hem, 1985, p. 147). Uranium-238 has a half-life of 4.5 billion years. Its daughter products include radium-226 (half-life of 1,620 years) and radon-222 (half-life of 3.8 days). Radon-222, a decay product of radium-226, is a colorless, odorless, chemically inert, 









Figure 8. Relation between $\mathrm{pH}$ and arsenic concentration in groundwater samples collected from 75 wells in Lycoming County, Pennsylvania.

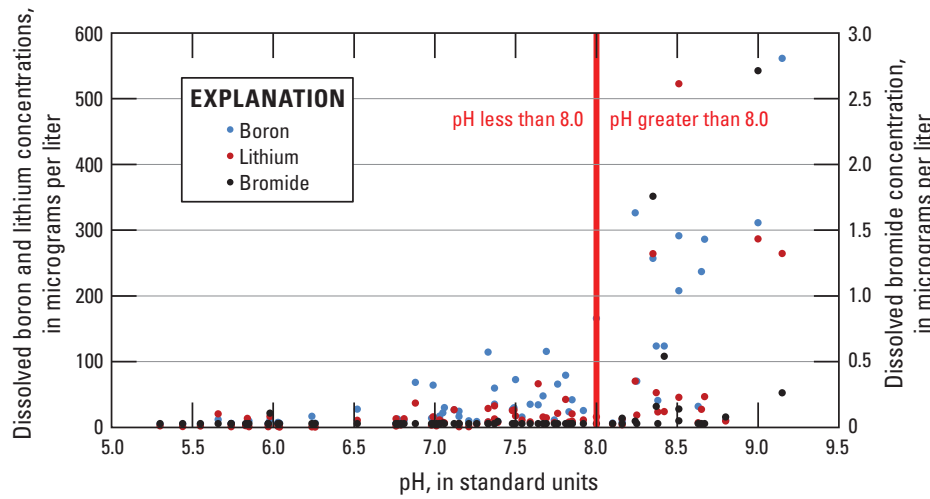

Figure 9. Relation between $\mathrm{pH}$ and boron, bromide, and lithium concentrations in groundwater samples collected from 75 wells in Lycoming County, Pennsylvania.



Figure 10. Relation between $\mathrm{pH}$ and fluoride and sodium concentrations in groundwater samples collected from 75 wells in Lycoming County, Pennsylvania. alpha-particle-emitting gas, which is soluble in water. The end product of the decay series is the stable isotope lead-206.

Activities of radon-222 in water from the 75 sampled wells ranged from less than the detection limit to $7,420 \mathrm{pCi} / \mathrm{L}$ with a median activity of $863 \mathrm{pCi} / \mathrm{L}$ (table 5). The EPA does not regulate radon-222 in drinking water; however, under the framework specified by the 1999 Notice for the Proposed Radon in Drinking Water Rule (Federal Register, 1999), the EPA proposed an alternative maximum contaminant level (AMCL) of 4,000 $\mathrm{pCi} / \mathrm{L}$ for radon-222 for community water systems that use groundwater for all or some of the supply in States with an enhanced indoor air radon program. Because indoor air radon-222 is the second leading cause of lung cancer, the EPA proposed a drinking-water MCL of $300 \mathrm{pCi} / \mathrm{L}$ for radon-222 for States without an enhanced indoor air program. Water samples from 50 of the 75 wells sampled (67 percent) exceeded the proposed EPA MCL of $300 \mathrm{pCi} / \mathrm{L}$, and 3 samples (4 percent) exceeded the proposed EPA AMCL of $4,000 \mathrm{pCi} / \mathrm{L}$ for radon-222.

The gross alpha-particle radioactivity (72-hour count) in water from the 75 sampled wells ranged from less than the detection limit to $6.4 \mathrm{pCi} / \mathrm{L}$; the median activity level was $0.53 \mathrm{pCi} / \mathrm{L}$ (table 5 ). Alpha particles are counted at 72 hours and 30 days because some alpha-particle emitters, such as radium-224 (half-life of 3.6 days), would not be present in the 30-day count. Gross alpha-particle activity in the 30-day count was similar to the activity in the 72-hour count (table 5). No water samples exceeded the EPA MCL of $15 \mathrm{pCi} / \mathrm{L}$ for gross alpha-particle activity (table 2).

The gross-beta particle radioactivity (72-hour count) ranged from less than the detection limit to $11.0 \mathrm{pCi} / \mathrm{L}$. Gross beta-particle activity in the 30-day count was similar to the activity in the 72-hour count in about one-half of the samples (table 5). The concentration of uranium ranged from $<0.014$ to $7.65 \mu \mathrm{g} / \mathrm{L}$. The median concentration was $0.113 \mu \mathrm{g} / \mathrm{L}$. No water samples exceeded the EPA MCL of $30 \mu \mathrm{g} / \mathrm{L}$ for uranium.

A subset of samples collected from 10 wells were analyzed for the radium isotopes radium-226 and radium-228. Concentrations (activities) of radium-226 ranged from 0.028 to $0.2 \mathrm{pCi} / \mathrm{L}$ in water samples, whereas activities of radium-228 ranged from non-detect to 0.5 from the 10 wells. Activities were less than the drinking-water standard of $5 \mathrm{pCi} / \mathrm{L}$ for combined radium-226 and radium-228. The highest activities of radium-226 and radium-228 were in water samples collected from the same well. Although the well with the highest radium-226 and radium-228 activities did also exhibit the highest 30 -day gross alpha activity among the subset of 10 wells sampled, it did not exhibit correspondingly high 30-day gross beta activity or 72-day gross alpha or beta activities. 
Table 5. Minimum, median, and maximum concentrations of radionuclides for water samples collected from 75 wells in Lycoming County, Pennsylvania, June-August 2014. Laboratory analysis for total concentrations of gross alpha and beta in unfiltered samples and radium-226 and radium-228 concentrations in filtered samples from a subset of wells done by TestAmerica, Inc. and dissolved concentrations in filtered samples done by U.S. Geological Survey National Water Quality Laboratory.

[nd, not detected; pCi/L, picocuries per liter; $\mu \mathrm{g} / \mathrm{L}$, microgram per liter; <, less than; --, no data or not applicable; EPA, U.S. Environmental Protection Agency; MCL, maximum contaminant level; HAL, health advisory level]

\begin{tabular}{|c|c|c|c|c|c|c|c|c|}
\hline Radionuclides & Units & $\begin{array}{c}\text { Number } \\
\text { (percent) } \\
\text { above } \\
\text { reporting } \\
\text { level }\end{array}$ & Minimum & Median & $\begin{array}{c}\text { Maxi- } \\
\text { mum }\end{array}$ & $\begin{array}{l}\text { Number } \\
\text { (percent) } \\
\text { exceeding } \\
\text { standard }\end{array}$ & $\begin{array}{l}\text { EPA } \\
\text { MCL }\end{array}$ & $\begin{array}{l}\text { EPA } \\
\text { HAL }\end{array}$ \\
\hline \multicolumn{9}{|c|}{ Total (unfiltered sample) } \\
\hline Gross alpha radioactivity, 72-hour count & $\mathrm{pCi} / \mathrm{L}$ & $34(45)$ & nd & 0.53 & 6.4 & $0(0)$ & 15 & -- \\
\hline Gross beta radioactivity, 30-day recount & $\mathrm{pCi} / \mathrm{L}$ & $52(69)$ & nd & 1.8 & 13.0 & $0(0)$ & 4 millirems per year & -- \\
\hline Gross beta radioactivity, 72-hour count & $\mathrm{pCi} / \mathrm{L}$ & $44(59)$ & nd & 1.5 & 11.0 & $0(0)$ & 4 millirems per year & -- \\
\hline Uranium (natural) & $\mu \mathrm{g} / \mathrm{L}$ & $54(72)$ & $<0.014$ & 0.113 & 7.65 & $0(0)$ & 30 & 20 \\
\hline \multicolumn{9}{|c|}{ Radium-226 and Radium-228 (filtered sample collected from a subset of 10 wells) } \\
\hline Radium-226 & $\mathrm{pCi} / \mathrm{L}$ & $10(100)$ & 0.028 & 0.07 & 0.2 & $0(0)$ & ${ }^{2} 5$ & -- \\
\hline Radium-228 & $\mathrm{pCi} / \mathrm{L}$ & $5(50)$ & nd & nd & 0.5 & $0(0)$ & 25 & -- \\
\hline
\end{tabular}

150 samples (67 percent) exceed proposed MCL of $300 \mathrm{pCi} / \mathrm{L}$ and 3 samples (4 percent) exceed proposed alternative $\mathrm{MCL}$ of 4,000 pCi/L.

${ }^{2} \mathrm{MCL}$ of $5 \mathrm{pCi} / \mathrm{L}$ is combined radium-226 and radium-228.

\section{Dissolved Methane and Other Naturally Occurring Hydrocarbon Gases}

Water sampled from the 75 wells had concentrations of dissolved methane (table 6) ranging from $<0.01$ to $16.8 \mathrm{mg} / \mathrm{L}$, plus lower to non-detectable concentrations of other more complex hydrocarbon gases, including ethane, ethylene, propane, propylene, iso-butane, and N-butane. None of the samples had detectable concentrations of the dissolved hydrocarbons iso-pentane, N-pentane, and hexane.

Only 15 of the 75 wells sampled ( 20 percent) had dissolved methane concentrations greater than the reporting level of $<0.01 \mathrm{mg} / \mathrm{L}$ (table 6 ). The median dissolved methane concentration was $<0.01 \mathrm{mg} / \mathrm{L}$, and the 15 detected concentrations ranged from 0.4 to $16.8 \mathrm{mg} / \mathrm{L}$ (table 6). Two of the samples ( 3 percent) had dissolved methane concentrations that exceeded the Pennsylvania action level of $7 \mathrm{mg} / \mathrm{L}$ (Commonwealth of Pennsylvania, 2014). Most samples with detectable concentrations of methane had alkaline $\mathrm{pH}$; 13 of 15 water samples in which methane was detected had $\mathrm{pH}$ greater than 7.5 (fig. 11). Eight of these 13 samples also had low concentrations of DO $(<0.5 \mathrm{mg} / \mathrm{L}$; fig. 11).

\section{Manmade Organic Compounds}

All samples were analyzed for 77 selected manmade organic compounds, including 66 VOCs, 10 glycols and alcohols, and oil and grease (table 7). Out of these manmade organic compounds, five were measured in detectable concentrations in five of the 75 wells sampled ( 7 percent). The following four VOCs were detected in four wells: chloromethane, methyl tert-butyl ether, methyl ethyl ketone, and trichloromethane (the only trihalomethane detected). Also, oil and grease were detected in one well.

VOCs include a wide range of natural and synthetic carbon-based compounds that have high vapor pressure and relatively low solubility in water. VOCs are used in industrial, commercial, and domestic applications and can enter the groundwater as liquid through spills and leaks or by atmospheric deposition. VOCs typically present in groundwater include industrial solvents, fuel hydrocarbons and oxidizers, fumigants, organic synthesis compounds, refrigerants, and disinfection byproducts (trihalomethanes) (Carter and others, 2007). VOCs are the most commonly found contaminant class associated with industrial and commercial sites, dumps, 
Table 6. Minimum, median, and maximum concentrations of methane and ethane determined in the laboratory for water samples collected from 75 wells in Lycoming County, Pennsylvania, June-August 2014. Laboratory analysis for total concentrations in unfiltered samples done by Seewald Laboratories Incorporated.

[mg/L, milligram per liter; $\mu \mathrm{g} / \mathrm{L}$, microgram per liter; <, less than; --, no data or not applicable]

\begin{tabular}{lccccc}
\hline & Units & $\begin{array}{c}\text { Number (percent) } \\
\text { above reporting } \\
\text { level }\end{array}$ & Minimum & Median & $\begin{array}{c}\text { Number (percent) } \\
\text { exceeding Penn- } \\
\text { sylvania action } \\
\text { level }\end{array}$ \\
\hline Methane & $\mathrm{mg} / \mathrm{L}$ & $15(20)$ & $<0.01$ & $<0.01$ & 16.8 \\
Ethane & $\mu \mathrm{g} / \mathrm{L}$ & $2(3)$ & $<10$ & $<10$ & 47.8 \\
\hline
\end{tabular}

${ }^{1}$ Two samples had methane concentrations (13.1 and $16.8 \mathrm{mg} / \mathrm{L}$ ) exceeding the Pennsylvania action level of $7 \mathrm{mg} / \mathrm{L}$ (Commonwealth of Pennsylvania, 2014).

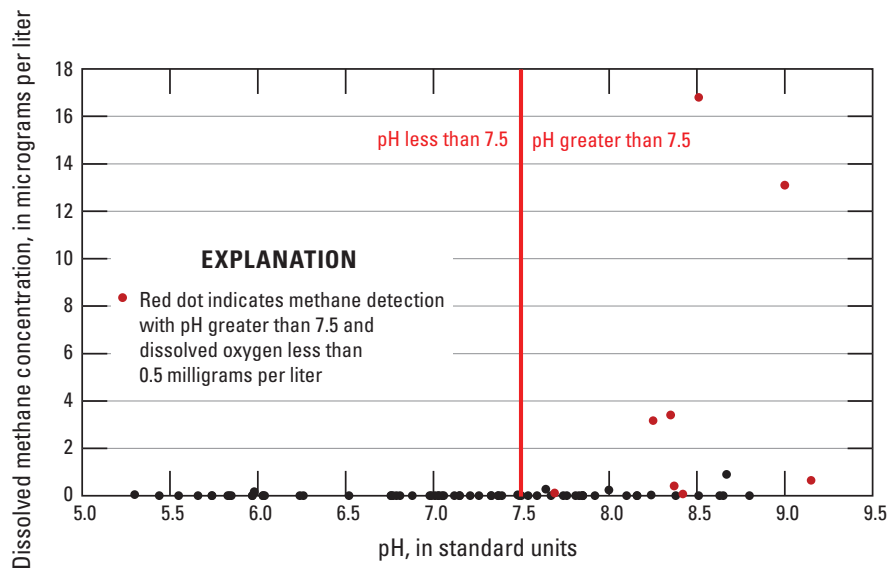

Figure 11. Relation between $\mathrm{pH}$ and dissolved methane concentration in groundwater samples collected from 75 wells in Lycoming County, Pennsylvania.

landfills, hazardous waste facilities, and military bases (Zogorski and others, 2006) and are widespread wherever human activities are present. Historically, many waste chemicals were disposed of indiscriminately, and the widespread use of VOCs has resulted in considerable mass of material released to the environment. Localized releases of VOCs can come from many sources, including leakage from storage tanks, direct application of pesticides containing VOCs (Barbash and Resek, 1996), septic systems, and leaking sewer systems. VOCs also are released to the atmosphere through engine exhausts, aerosol sprays, leakage of refrigerants, and application of fumigants and pesticides. Trihalomethanes (THMs) are frequently associated with chlorinated water and chlorinated cleaning products.

The reporting level for VOCs was $0.5 \mu \mathrm{g} / \mathrm{L}$, which is lower than drinking-water MCLs established for 14 of the 68 analyzed VOCs (U.S. Environmental Protection Agency, 2012); however, drinking-water MCLs for two compounds-1,2-dibromo-3-chloropropane and 1,2-dibromoethane-are less than the method reporting level as performed by the laboratory, so for these compounds, a more sensitive method is needed to determine if they are present in concentrations greater than the MCLs (although below the reporting level of $0.5 \mu \mathrm{g} / \mathrm{L})$. Therefore, with the exception of these two compounds, if VOCs are present in groundwater at concentrations less than the reporting level of $0.5 \mu \mathrm{g} / \mathrm{L}$, those concentrations would not exceed an established drinking-water standard. MCLs have not been established for VOCs where data are insufficient to evaluate human-health effects.

Of the 66 VOCs analyzed in the 75 groundwater samples, only 4 were detected at or above the reporting level: 2-Butanone (also known as methyl ethyl ketone or MEK) at $1.45 \mu \mathrm{g} / \mathrm{L}$, methyl chloride (also known as chloromethane) at $1.68 \mu \mathrm{g} / \mathrm{L}$, methyl tert-butyl ether (also known as MTBE) at $1.96 \mu \mathrm{g} / \mathrm{L}$, and trichloromethane (considered a THM) at $24.8 \mu \mathrm{g} / \mathrm{L}$. None of the detected VOCs were detected in samples from the same well, and concentrations of the detected VOCs did not exceed any established EPA drinking-water standard. MEK is a common laboratory contaminant, but this VOC was not detected in the field blank samples analyzed by SLI or USGS NWQL (Ohio Environmental Protection Agency, 2012). Although the measured VOC concentrations do not exceed established standards, the detection of these manmade compounds in groundwater indicates groundwater contamination by human activities.

The reporting level for the analyzed glycols and alcohols and oil and grease was $5 \mathrm{mg} / \mathrm{L}$, a level that may not be low enough to detect possible presence of those compounds in groundwater; however, at the time of this study, a more sensitive approved method with lower reporting levels was not available. Therefore, these analyses only indicate that glycols and alcohols were not present in concentrations greater than $5 \mathrm{mg} / \mathrm{L}$. Oil and grease were detected in one sample at a concentration of $11.1 \mathrm{mg} / \mathrm{L}$. As of 2015, there are no established EPA drinking-water standards for oil and grease. 
Table 7. Reporting levels and drinking-water standards (U.S. Environmental Protection Agency, 2012) for manmade organic compounds analyzed in water samples collected from 75 wells in Lycoming County, Pennsylvania, June-August 2014. Laboratory analysis for total concentrations in unfiltered samples done by Seewald Laboratories Incorporated.

$[\mu \mathrm{g} / \mathrm{L}$, microgram per liter; $\mathrm{mg} / \mathrm{L}$, milligram per liter; \%, percent; --, no data or not applicable; EPA, U.S. Environmental Protection Agency; MCL, maximum contaminant level; SMCL, secondary maximum contaminant level; HAL, health advisory level]

\begin{tabular}{|c|c|c|c|c|c|}
\hline $\begin{array}{c}\text { Constituent } \\
\text { name }\end{array}$ & Units & $\begin{array}{l}\text { Reporting } \\
\text { limit }\end{array}$ & $\begin{array}{l}\text { Number (per- } \\
\text { cent) exceed- } \\
\text { ing reporting } \\
\text { limit }\end{array}$ & $\begin{array}{l}\text { EPA } \\
\text { MCL }\end{array}$ & $\begin{array}{l}\text { EPA } \\
\text { HAL }\end{array}$ \\
\hline \multicolumn{6}{|c|}{ Volatile organic compounds } \\
\hline 1,1,1,2-Tetrachloroethane & $\mu \mathrm{g} / \mathrm{L}$ & 0.5 & $0(0)$ & -- & 70 \\
\hline 1,1,1-Trichloroethane & $\mu \mathrm{g} / \mathrm{L}$ & 0.5 & $0(0)$ & 200 & -- \\
\hline 1,1,2-Trichloroethane & $\mu \mathrm{g} / \mathrm{L}$ & 0.5 & $0(0)$ & 5 & -- \\
\hline 1,1-Dichloroethane & $\mu \mathrm{g} / \mathrm{L}$ & 0.5 & $0(0)$ & -- & -- \\
\hline 1,1-Dichloroethene (1,1-Dichloroethylene) & $\mu \mathrm{g} / \mathrm{L}$ & 0.5 & $0(0)$ & 7 & -- \\
\hline 1,1-Dichloropropene & $\mu \mathrm{g} / \mathrm{L}$ & 0.5 & $0(0)$ & -- & -- \\
\hline 1,2,4-Trimethylbenzene & $\mu \mathrm{g} / \mathrm{L}$ & 0.5 & $0(0)$ & -- & -- \\
\hline 1,2-Dichlorobenzene (o-Dichlorobenzene) & $\mu \mathrm{g} / \mathrm{L}$ & 0.5 & $0(0)$ & 600 & -- \\
\hline 1,2-Dichloroethane & $\mu \mathrm{g} / \mathrm{L}$ & 0.5 & $0(0)$ & 5 & -- \\
\hline 1,2-Dichloropropane & $\mu \mathrm{g} / \mathrm{L}$ & 0.5 & $0(0)$ & 5 & -- \\
\hline 1,3,5-Trimethylbenzene & $\mu \mathrm{g} / \mathrm{L}$ & 0.5 & $0(0)$ & -- & -- \\
\hline 1,3-Dichlorobenzene ( $m$-Dichlorobenzene) & $\mu \mathrm{g} / \mathrm{L}$ & 0.5 & $0(0)$ & -- & 600 \\
\hline 1,3-Dichloropropane & $\mu \mathrm{g} / \mathrm{L}$ & 0.5 & $0(0)$ & -- & -- \\
\hline 1,4-Dichlorobenzene ( $p$-Dichlorobenzene) & $\mu \mathrm{g} / \mathrm{L}$ & 0.5 & $0(0)$ & 75 & -- \\
\hline 2,2-Dichloropropane & $\mu \mathrm{g} / \mathrm{L}$ & 0.5 & $0(0)$ & -- & -- \\
\hline Acetone & $\mu \mathrm{g} / \mathrm{L}$ & 1 & $0(0)$ & -- & -- \\
\hline Benzene & $\mu \mathrm{g} / \mathrm{L}$ & 0.5 & $0(0)$ & 5 & -- \\
\hline Bromobenzene & $\mu \mathrm{g} / \mathrm{L}$ & 0.5 & $0(0)$ & -- & 60 \\
\hline Bromochloromethane & $\mu \mathrm{g} / \mathrm{L}$ & 0.5 & $0(0)$ & -- & 90 \\
\hline Bromodichloromethane & $\mu \mathrm{g} / \mathrm{L}$ & 0.5 & $0(0)$ & ${ }^{1} 80$ & -- \\
\hline Bromoform (Tribromomethane) & $\mu \mathrm{g} / \mathrm{L}$ & 0.5 & $0(0)$ & ${ }^{1} 80$ & -- \\
\hline Bromomethane (Methyl bromide) & $\mu \mathrm{g} / \mathrm{L}$ & 0.5 & $0(0)$ & -- & 10 \\
\hline Carbon Disulfide & $\mu \mathrm{g} / \mathrm{L}$ & 0.5 & $0(0)$ & -- & -- \\
\hline Carbon Tetrachloride (Tetrachloromethane) & $\mu \mathrm{g} / \mathrm{L}$ & 0.5 & $0(0)$ & 5 & -- \\
\hline Chlorobenzene & $\mu \mathrm{g} / \mathrm{L}$ & 0.5 & $0(0)$ & -- & -- \\
\hline Chloroethane & $\mu \mathrm{g} / \mathrm{L}$ & 0.5 & $0(0)$ & -- & -- \\
\hline cis-1,2-dichloroethene & $\mu \mathrm{g} / \mathrm{L}$ & 0.5 & $0(0)$ & 70 & -- \\
\hline cis-1,3-dichloropropene & $\mu \mathrm{g} / \mathrm{L}$ & 0.5 & $0(0)$ & -- & 40 \\
\hline
\end{tabular}


Table 7. Reporting levels and drinking-water standards (U.S. Environmental Protection Agency, 2012) for manmade organic compounds analyzed in water samples collected from 75 wells in Lycoming County, Pennsylvania, June-August 2014. Laboratory analysis for total concentrations in unfiltered samples done by Seewald Laboratories Incorporated.-Continued

[ $\mu \mathrm{g} / \mathrm{L}$, microgram per liter; mg/L, milligram per liter; \%, percent; --, no data or not applicable; EPA, U.S. Environmental Protection Agency; MCL, maximum contaminant level; SMCL, secondary maximum contaminant level; HAL, health advisory level]

\begin{tabular}{|c|c|c|c|c|c|}
\hline $\begin{array}{c}\text { Constituent } \\
\text { name }\end{array}$ & Units & $\begin{array}{l}\text { Reporting } \\
\text { limit }\end{array}$ & $\begin{array}{l}\text { Number (per- } \\
\text { cent) exceed- } \\
\text { ing reporting } \\
\text { limit }\end{array}$ & $\begin{array}{l}\text { EPA } \\
\text { MCL }\end{array}$ & $\begin{array}{l}\text { EPA } \\
\text { HAL }\end{array}$ \\
\hline Dibromochloromethane & $\mu \mathrm{g} / \mathrm{L}$ & 0.5 & $0(0)$ & ${ }^{1} 80$ & -- \\
\hline Dibromomethane & $\mu \mathrm{g} / \mathrm{L}$ & 0.5 & $0(0)$ & -- & -- \\
\hline Dichlorodifluoromethane (Freon 12) & $\mu \mathrm{g} / \mathrm{L}$ & 0.5 & $0(0)$ & -- & 1,000 \\
\hline Hexachlorobutadiene (1,3-Hexachlorobutadiene) & $\mu \mathrm{g} / \mathrm{L}$ & 0.5 & $0(0)$ & -- & 10 \\
\hline Iodomethane (Methyl iodide) & $\mu \mathrm{g} / \mathrm{L}$ & 0.5 & $0(0)$ & -- & -- \\
\hline Isopropylbenzene (Cumene) & $\mu \mathrm{g} / \mathrm{L}$ & 0.5 & $0(0)$ & -- & 4 \\
\hline$m+p$-Xylene ( $m$-Xylene plus $p$-xylene) & $\mu \mathrm{g} / \mathrm{L}$ & 1 & $0(0)$ & 10,000 & -- \\
\hline Naphthalene & $\mu \mathrm{g} / \mathrm{L}$ & 0.5 & $0(0)$ & -- & 100 \\
\hline$n$-Butylbenzene & $\mu \mathrm{g} / \mathrm{L}$ & 0.5 & $0(0)$ & -- & -- \\
\hline$n$-Propylbenzene & $\mu \mathrm{g} / \mathrm{L}$ & 0.5 & $0(0)$ & -- & -- \\
\hline$o$-Xylene & $\mu \mathrm{g} / \mathrm{L}$ & 0.5 & $0(0)$ & 10,000 & -- \\
\hline$p$-Isopropyltoluene (4-Isopropyltoluene) & $\mu \mathrm{g} / \mathrm{L}$ & 0.5 & $0(0)$ & -- & -- \\
\hline sec-Butylbenzene & $\mu \mathrm{g} / \mathrm{L}$ & 0.5 & $0(0)$ & -- & -- \\
\hline Styrene & $\mu \mathrm{g} / \mathrm{L}$ & 0.5 & $0(0)$ & 100 & -- \\
\hline tert-Butylbenzene & $\mu \mathrm{g} / \mathrm{L}$ & 0.5 & $0(0)$ & -- & -- \\
\hline Tetrachloroethene (Perchloroethylene, PCE) & $\mu \mathrm{g} / \mathrm{L}$ & 0.5 & $0(0)$ & 5 & -- \\
\hline Total trihalomethanes (TTHMs) & $\mu \mathrm{g} / \mathrm{L}$ & 0.5 & $1(1)$ & ${ }^{1} 80$ & -- \\
\hline Vinyl Acetate & $\mu \mathrm{g} / \mathrm{L}$ & 0.5 & $0(0)$ & -- & -- \\
\hline Vinyl Chloride (Chloroethene) & $\mu \mathrm{g} / \mathrm{L}$ & 0.5 & $0(0)$ & 2 & -- \\
\hline \multicolumn{6}{|c|}{ Glycols and alcohols } \\
\hline Ethanol & $\mathrm{mg} / \mathrm{L}$ & 5 & $0(0)$ & -- & -- \\
\hline Ethylene glycol & $\mathrm{mg} / \mathrm{L}$ & 5 & $0(0)$ & 14 & -- \\
\hline Isobutyl alcohol (2-Methyl-1-propanol) & $\mathrm{mg} / \mathrm{L}$ & 5 & $0(0)$ & -- & -- \\
\hline Isopropyl Alcohol (2-Propanol) & $\mathrm{mg} / \mathrm{L}$ & 5 & $0(0)$ & -- & -- \\
\hline Methanol & $\mathrm{mg} / \mathrm{L}$ & 5 & $0(0)$ & -- & -- \\
\hline$n$-Butanol (1-Butanol, n-Butyl alcohol) & $\mathrm{mg} / \mathrm{L}$ & 5 & $0(0)$ & -- & -- \\
\hline$n$-Propanol (1-Propanol) & $\mathrm{mg} / \mathrm{L}$ & 5 & $0(0)$ & -- & -- \\
\hline Propylene glycol & $\mathrm{mg} / \mathrm{L}$ & 5 & $0(0)$ & -- & -- \\
\hline
\end{tabular}


Table 7. Reporting levels and drinking-water standards (U.S. Environmental Protection Agency, 2012) for manmade organic compounds analyzed in water samples collected from 75 wells in Lycoming County, Pennsylvania, June-August 2014. Laboratory analysis for total concentrations in unfiltered samples done by Seewald Laboratories Incorporated.-Continued

$[\mu \mathrm{g} / \mathrm{L}$, microgram per liter; $\mathrm{mg} / \mathrm{L}$, milligram per liter; \%, percent; --, no data or not applicable; EPA, U.S. Environmental Protection Agency; MCL, maximum contaminant level; SMCL, secondary maximum contaminant level; HAL, health advisory level]

\begin{tabular}{llccc}
\hline \multicolumn{1}{c}{$\begin{array}{c}\text { Constituent } \\
\text { name }\end{array}$} & Units & $\begin{array}{c}\text { Reporting } \\
\text { limit }\end{array}$ & $\begin{array}{c}\text { Number (per- } \\
\text { cent) exceed- } \\
\text { ing reporting } \\
\text { limit }\end{array}$ & $\begin{array}{c}\text { EPA } \\
\text { MCL }\end{array}$ \\
\hline sec-Butyl alcohol & $\begin{array}{l}\text { EPA } \\
\text { HAL }\end{array}$ & $0(0)$ & -- \\
tert-Butyl Alcohol (2-Methyl-2-propanol, TBA) & $\mathrm{mg} / \mathrm{L}$ & 5 & $0(0)$ & -- \\
\hline & Oil and grease & & - \\
\hline Oil and grease & $\mathrm{mg} / \mathrm{L}$ & 5 & $1(1)$ & -- \\
\hline
\end{tabular}

1998 Final Rule for Disinfectants and Disinfection By-products: The total for trihalomethanes (TTHMs) is $80 \mu \mathrm{g} / \mathrm{L}$.

\section{Relations Among Constituents in Groundwater}

Dissolved constituents in groundwater may be derived from atmospheric, geologic, biologic, and anthropogenic sources as the aqueous solution interacts with various materials along transport pathways. Solute concentrations can range widely depending on the presence of constituent elements in the source(s), the extent of contact between water and the source, the aqueous solubility and interactions among the dissolved elements, and geochemical conditions such as $\mathrm{pH}$ and redox state that affect element form, mobility, and transport in the aqueous environment.

Major ions commonly are derived by the dissolution of common minerals, including carbonates, silicates, oxides, sulfates, and sulfides, and can be influenced by ion-exchange, redox processes, and mixing of freshwater with residual brines that remain in the aquifer matrix or that could be mobilized from deep sources. The concentrations of major ions, TDS, salinity, and SC of groundwater are directly related and generally expected to increase with progressive evaporation or dissolution of minerals (Hem, 1985). The concentrations of trace elements in solution may increase with TDS or SC, not only because of the release of trace constituents with the major ions dissolved from minerals, but because of the potential for displacement of adsorbed or exchangeable trace ions from mineral surfaces by the major ions.

Major cations (positively charged ions such as calcium, magnesium, sodium, and potassium), major anions (negatively charged ions such as sulfate, chloride, fluoride, and bicarbonate), and nonionic solutes (uncharged solutes such as silica) typically are present in natural waters at concentrations $>1 \mathrm{mg} / \mathrm{L}$, whereas dissolved trace constituents (such as iron, manganese, zinc, lead, copper, nickel, vanadium, molybdenum, arsenic, selenium, radium, uranium, lithium, and bromide) typically are present at concentrations $<1 \mathrm{mg} / \mathrm{L}$ (Hem, 1985). Concentrations of DO and nutrients (such as nitrogen and phosphorus compounds) commonly range from values $<1 \mathrm{mg} / \mathrm{L}$ to values $>1 \mathrm{mg} / \mathrm{L}$ because of biological processes that involve the production or metabolism of organic carbon compounds that contain nitrogen and phosphorus. Although biological (biochemical) processes can affect the concentrations of nutrients and trace constituents in groundwater directly or indirectly because of changes to $\mathrm{pH}$ and redox, such processes generally have minor effects on major ion concentrations.

\section{Conceptual Hydrogeochemical Setting}

Brines with elevated concentrations of sodium, chloride, bromide, barium, strontium, and other solutes occupy pore spaces in deep-lying sedimentary rocks throughout Pennsylvania. The highly saline sodium chloride brines and overlying groundwaters of intermediate salinity generally are present 1,000 feet or more below the surface (Feth, 1965; Heisig and Scott, 2013). Such brine-influenced waters commonly are produced from gas or oil wells (Dresel and Rose, 2010; Hayes, 2009; Halusczak and others, 2013), and may affect water quality of springs and domestic-supply wells (Llewellyn, 2014; Siegel and others, 2015).

The shallowest flow systems tend to be highly fractured aquifers where actively circulating freshwater has depleted sodium, chloride, and other vestiges of connate brines (fig. 12). Groundwater composition evolves from calcium-magnesium-bicarbonate-sulfate type with relatively lower $\mathrm{pH}$ and higher $\mathrm{DO}$ concentrations in recharge areas and local flow zones to predominantly sodium-bicarbonatesulfate with higher $\mathrm{pH}$ and lower DO along intermediate flow paths. Deeper or regional groundwater that is relatively saline may be mixing with intermediate flow waters, especially in discharge areas, such as stream valleys, where methane from microbial and (or) thermogenic sources appears most frequently and in highest concentrations in northeastern Pennsylvania. In the shallow groundwater zone, water types of predominantly calcium-magnesium/bicarbonate and calciummagnesium/bicarbonate-sulfate compositions are produced 


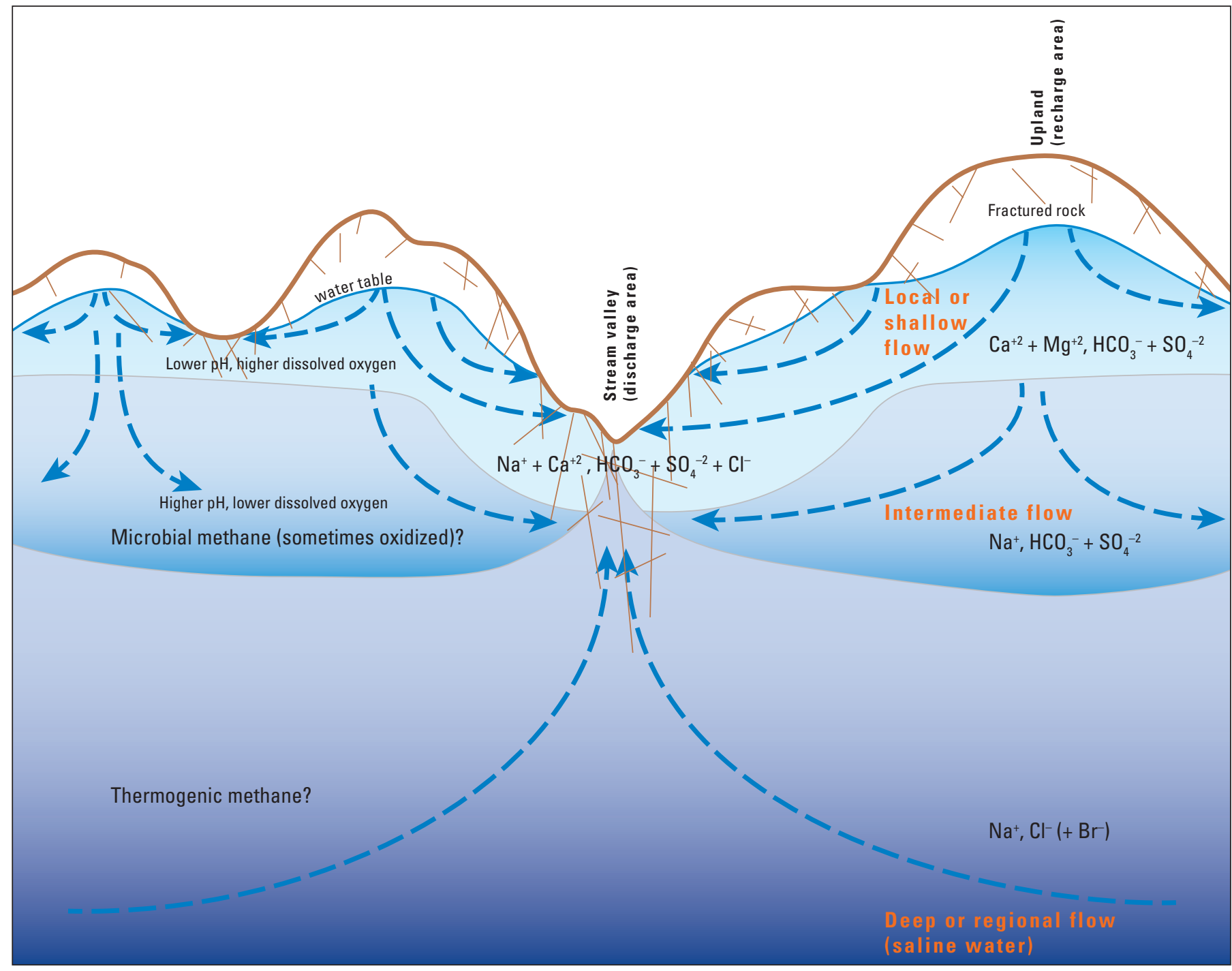

This diagram is not drawn to scale, and actual flow system depths may vary in relation to topographic features.

\section{EXPLANATION}

$\begin{array}{ll}\mathrm{Ca}^{+2}-\text { Calcium } & \mathrm{Br}-\text { Bromide } \\ \mathrm{Mg}^{+2} \text {-Magnesium } & \mathrm{Cl}^{-}-\text {Chloride } \\ \mathrm{Na}^{+} \text {-Sodium } & \mathrm{HCO}_{3}^{-} \text {-Bicarbonate } \\ \mathrm{SO}_{4}^{-2} \text {-Sulfate } & \end{array}$

Figure 12. Schematic diagram of generalized conceptual hydrogeochemical setting for fresh and saline groundwater in a fractured bedrock aquifer setting. 
by the active weathering of moderately soluble carbonate minerals, and to a lesser extent sulfate and sulfide minerals. In the intermediate zone, groundwater of sodium/bicarbonate type and moderate salinity typically is present between the shallow, actively circulating freshwater and the deeper, slower moving sodium chloride type waters. Poth (1962) described the freshening process in the intermediate zone as chloride being readily removed by circulating groundwater with sodium being more difficult to remove because much of it is adsorbed on the clay in the rocks. The sodium, which occupies exchange sites on clay minerals, tends to be displaced by calcium and magnesium. Such cation-exchange processes lead to the formation of sodium/bicarbonate type waters, which are transitional between the sodium chloride waters at great depth and the calcium-magnesium/bicarbonate waters in the overlying freshwater zone.

Most wells constructed for domestic use are completed within the local, freshwater flow system. The wells sampled in Lycoming County for this study were completed to depths ranging from 40 to 620 feet, with one-half drilled to depths of 175 to 400 feet. Neither of the two deepest wells, LY745 and LY755, completed to depths of 600 and 620 feet below the surface, respectively, exhibited characteristics of brineinfluenced waters; however, several wells about one-half that depth had characteristics indicative of such influence, notably elevated SC and TDS dominated by sodium and chloride, plus elevated concentrations of bromide, lithium, and methane, as explained in more detail below.

\section{Correlations Among Major and Trace Constituents in Groundwater}

Evaluation of the correlations among chemical constituents and environmental variables provides insight on hydrochemical processes affecting groundwater chemistry in the study area.

\section{Relations Among pH, Specific Conductance, and Constituent Concentrations}

The chemical compositions of the 75 groundwater samples collected in Lycoming County during 2014 ranged widely, as indicated by $\mathrm{pH}$ values from 5.3 to 9.2 and $\mathrm{SC}$ from 20 to $3,120 \mu \mathrm{S} / \mathrm{cm}$ (fig. 13). Detection limits for bromide and arsenic were 0.03 and $0.0001 \mathrm{mg} / \mathrm{L}$, respectively; symbols plotted at those values were below detection (fig. 13). Most of the samples had $\mathrm{pH}$ values from 6.7 to 8.0 and $\mathrm{SC}$ from 150 to $300 \mu \mathrm{S} / \mathrm{cm}$. Only 3 of the 75 well-water samples in this study had SC values greater than $1,000 \mu \mathrm{S} / \mathrm{cm}$; these samples had alkaline $\mathrm{pH}(>8)$ values and greater concentrations of sodium and chloride than those for the other samples. In addition to figure 13, which shows the relations among $\mathrm{pH}, \mathrm{SC}$, and multiple inorganic constituents, boxplots are included in appendix 3 that show the overall relations among individual constituents with $\mathrm{pH}$ class interval (fig. 3-1) and SC class interval (fig. 3-2). Additional boxplots show the same constituents as a function of redox class interval (fig. 3-3) and lithology (fig. 3-4).

The $\mathrm{pH}$ for the 75 groundwater samples was positively correlated with SC and other measures of ionic strength, including TDS ROE, whereas the $\mathrm{pH}$ and $\mathrm{SC}$ were negatively correlated with the concentration of DO. With increased $\mathrm{pH}$ and SC, the concentrations of several major and trace constituents generally increased, including ALK, sodium, lithium, boron, fluoride, bromide, arsenic, and, to a lesser extent, strontium and barium (fig. 13). Despite positive correlations between $\mathrm{SC}$ and the concentration of chloride, sulfate, calcium, magnesium, or hardness (fig. 13), those constituents were not correlated with $\mathrm{pH}$ over the entire range of measured values. Concentrations of potassium were not correlated with $\mathrm{pH}$ or SC.

The relation between the $\mathrm{pH}$ and concentrations of calcium, magnesium, and hardness changes from positive to negative at about $\mathrm{pH} 7.5$ (fig. 13). For $\mathrm{pH}$ values $<7.5$, the concentrations of hardness, calcium, magnesium, and other cations, including strontium, barium, sodium, potassium, and lithium, plus ALK, generally increased with $\mathrm{pH}$; however, for $\mathrm{pH}$ values greater than 7.5 , the concentrations of hardness, calcium, and magnesium decreased with increased $\mathrm{pH}$, whereas the SC and concentrations of sodium, ALK, and TDS continued to increase. Such trends in $\mathrm{pH}, \mathrm{SC}$, and constituent concentrations are consistent with the dissolution of calcite over the range of $\mathrm{pH}$ combined with cation-exchange at $\mathrm{pH}$ greater than 7.5. Through cation-exchange reactions, the hardness is removed, or "softened," as calcium and magnesium ions displace sodium ions from exchange sites on clay minerals (Appelo and Postma, 2005), as explained in more detail below.

Boxplots show the constituent concentrations for three different $\mathrm{pH}$ class intervals (fig. 3-1). As indicated by the scatter plots that showed constituent concentrations as a function of $\mathrm{pH}$ for all 75 samples (fig. 13), most constituent concentrations increased with $\mathrm{pH}$ to values of 7.4 (acidic to neutral range). The alkaline $\mathrm{pH}$ class ( $\mathrm{pH}>7.5$ ) had higher median values for SC, TDS, sodium, potassium, ALK, chloride, bromide, fluoride, boron, lithium, methane, barium, strontium, arsenic, and molybdenum than the acidic or near-neutral classes. In contrast, the alkaline $\mathrm{pH}$ class had lower or equal medians for hardness, calcium, magnesium, and DO.

Boxplots also show constituent concentrations for four different SC class intervals (fig. 3-2). As indicated by the scatter plots that showed constituent concentrations as a function of SC for all 75 samples (fig. 13), most constituent concentrations increased with SC to values approaching $700 \mu \mathrm{S} / \mathrm{cm}$. The highest $\mathrm{SC}$ class $(\mathrm{SC}>700 \mu \mathrm{S} / \mathrm{cm}$ ) had higher median values for $\mathrm{pH}$, TDS, sodium, potassium, ALK, chloride, bromide, fluoride, boron, lithium, methane, ammonia, and arsenic, and lower median values for DO, nitrate, aluminum, and zinc than the lower SC classes. The concentrations of nitrate and zinc were below detection in the highest SC class. Constituents that 

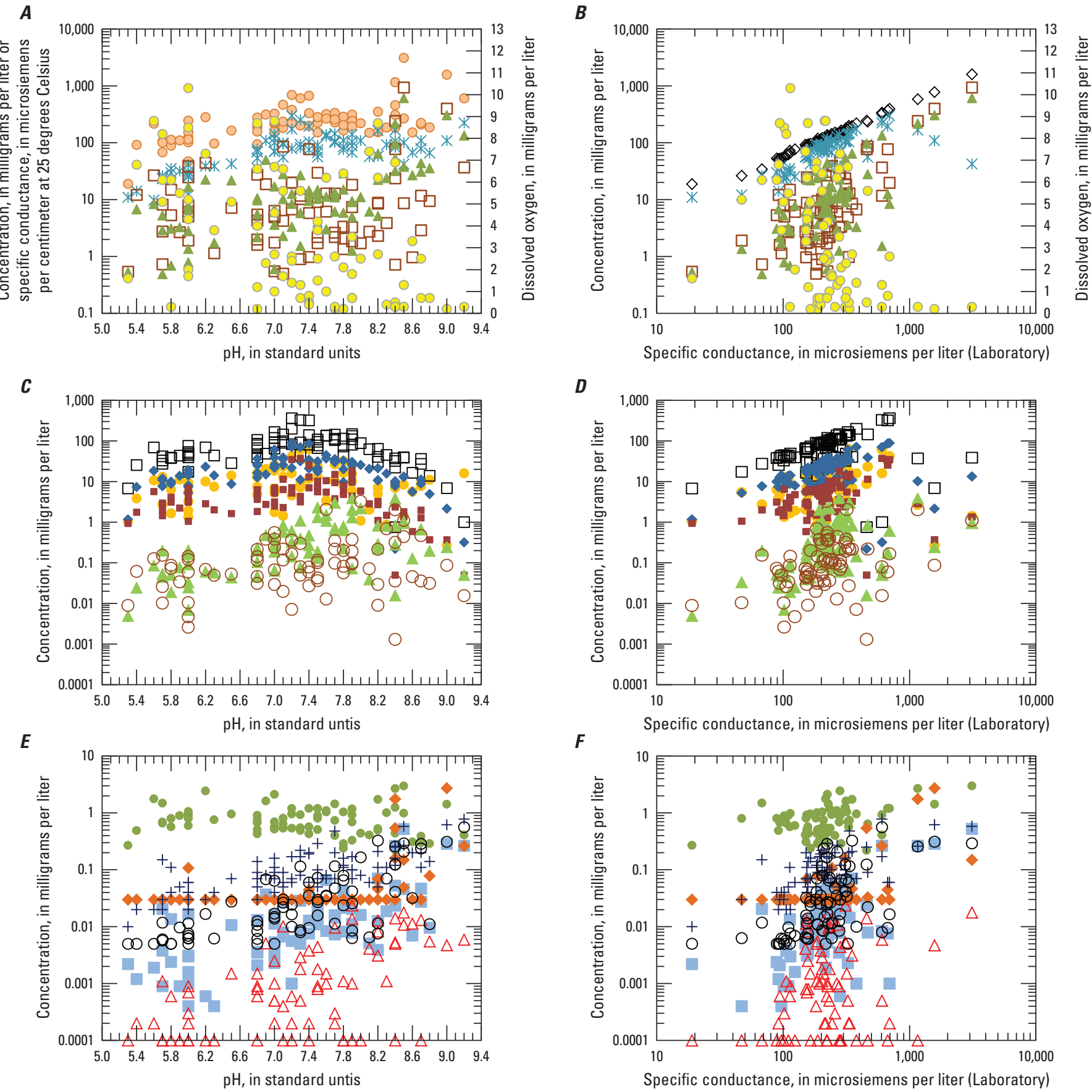

$\boldsymbol{F}$

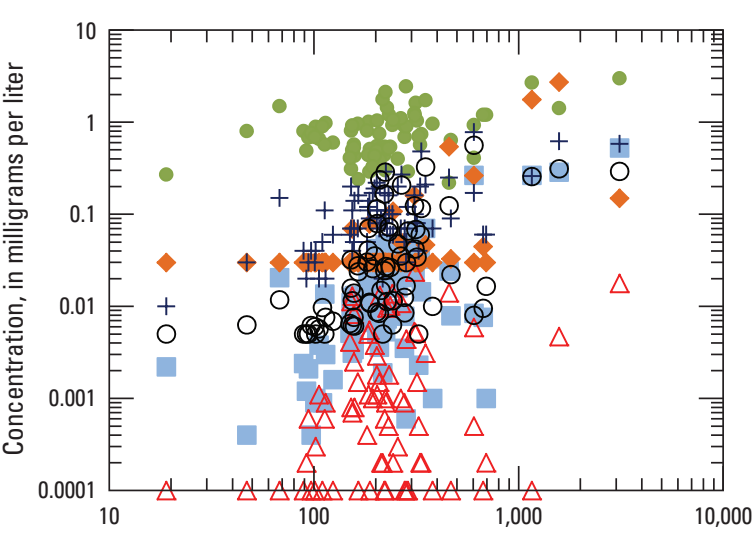

Specific conductance, in microsiemens per liter (Laboratory)

\section{EXPLANATION}
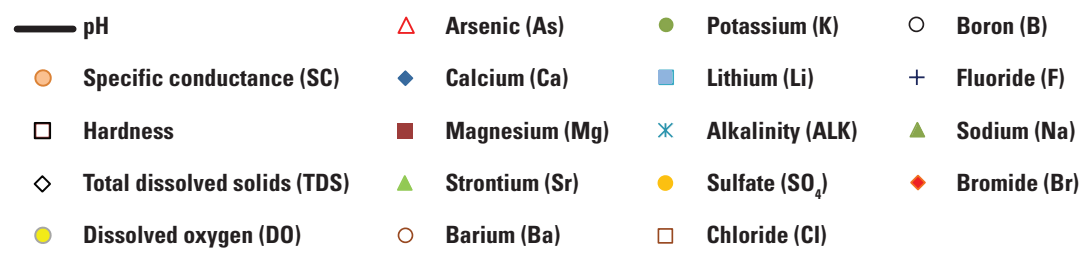

Figure 13. Concentrations of selected constituents in groundwater samples collected from 75 wells in Lycoming County, Pennsylvania, 2014 , compared to $A-C, \mathrm{pH}$; or $D-F$, specific conductance. 
did not vary with $\mathrm{SC}$ and (or) $\mathrm{pH}$ may be controlled by other factors, such as redox state.

The constituent concentrations for anoxic, mixed, and oxic redox class intervals also are illustrated as boxplots in appendix 3 (fig. 3-3). Although most constituent concentrations did not vary with redox, the medians for several constituents were significantly different between the anoxic and oxic redox classes. The anoxic samples had higher median values for $\mathrm{pH}$, bromide, fluoride, boron, ammonia, molybdenum, iron, and manganese, and lower median values for DO, nitrate, uranium, and radon-222 than the oxic samples.

\section{Ionic Contributions to Conductivity and Total Dissolved Solids}

Despite general correlations between SC and major ion concentrations, the predominance of various ionic contributions to the SC varied widely for samples with comparable values of SC (fig. 14). Calcium and bicarbonate were the
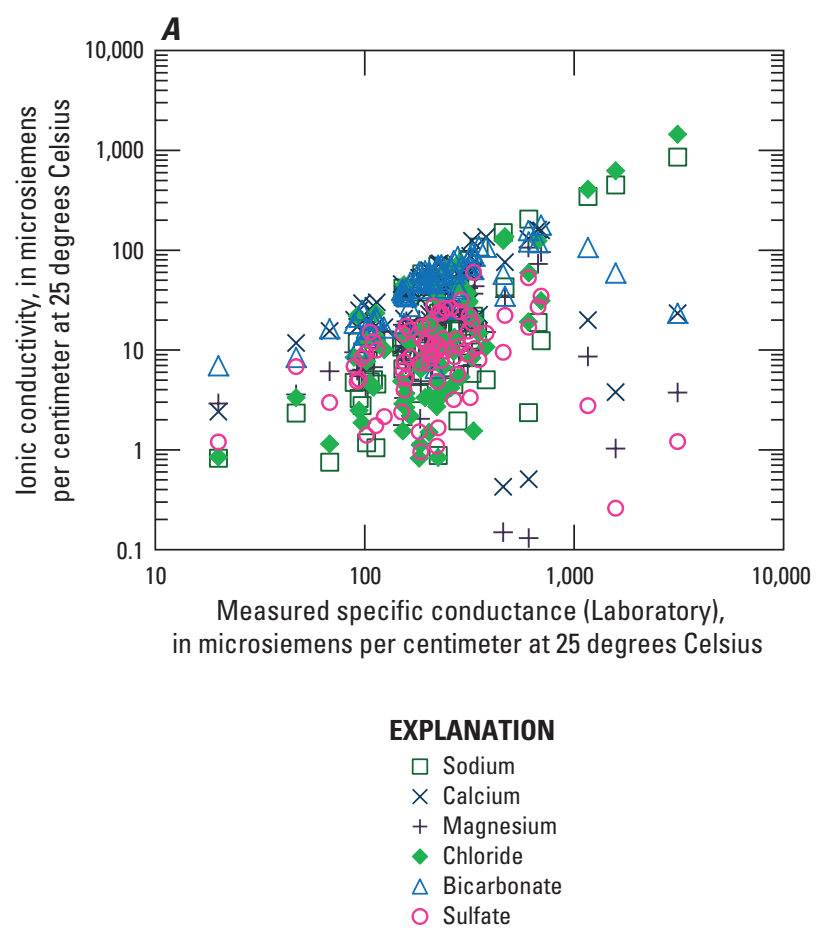

predominant ions in most samples, considering the ionic contributions to $\mathrm{SC}$ or considering the ion concentrations in units of mass, moles, or equivalents. Although sodium and chloride were subordinate in most samples, these constituents were the predominant ions in a few samples, particularly those with SC greater than $1,000 \mu \mathrm{S} / \mathrm{cm}$, but also in several samples with relatively low values of SC. Sulfate was subordinate to bicarbonate and chloride as a source of conductivity in the samples; its importance generally decreased with increased SC. Contributions by magnesium were comparable to sulfate; however, contributions by nitrate, potassium, hydrogen, hydroxyl, or carbonate ions were relatively minor.

Variations in the major ion species contributions to the $\mathrm{SC}$ values measured in the laboratory for six selected groundwater samples are illustrated as pie charts (fig. 15). To provide context, the samples illustrated in figure 14 are identified among all 75 samples in figure 15. Calcium, bicarbonate, magnesium, sodium, sulfate, and chloride ions are the predominant sources of conductivity for the average of the 75 samples and



Individual well sample, increasing specific conductance

EXPLANATION

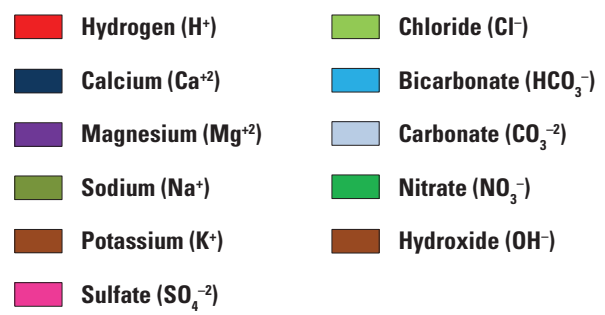

Figure 14. Major ion contributions to specific conductance (SC) for groundwater samples collected from 75 wells in Lycoming County, Pennsylvania, 2014. A, comparison of estimated ionic conductivity contributions by sodium, calcium, magnesium, chloride, bicarbonate, and sulfate to measured SC; and $B$, relative contributions by major ion species (hydrogen, calcium, magnesium, sodium, potassium, sulfate, chloride, bicarbonate, carbonate, nitrate, and hydroxide) to computed SC, expressed in percent, in order of increasing SC. Individual ion conductivities estimated from dissolved constituent concentrations as the "transport number" (relative contribution of a given ion to the overall conductivity, using methods of McCleskey and others, 2012) after aqueous speciation calculations with the aqueous geochemical computer program, PHREEOC (Parkhurst and Appelo, 2013). 


\section{A. $\mathrm{LY718;} \mathrm{SC}=20 ; \mathrm{pH}=5.3$}

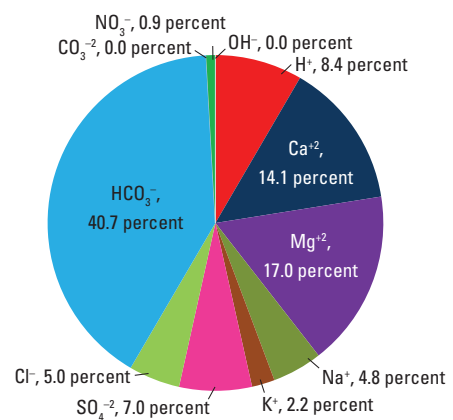

C. $\mathrm{LY} 732 ; \mathrm{SC}=94 ; \mathrm{pH}=6.8$
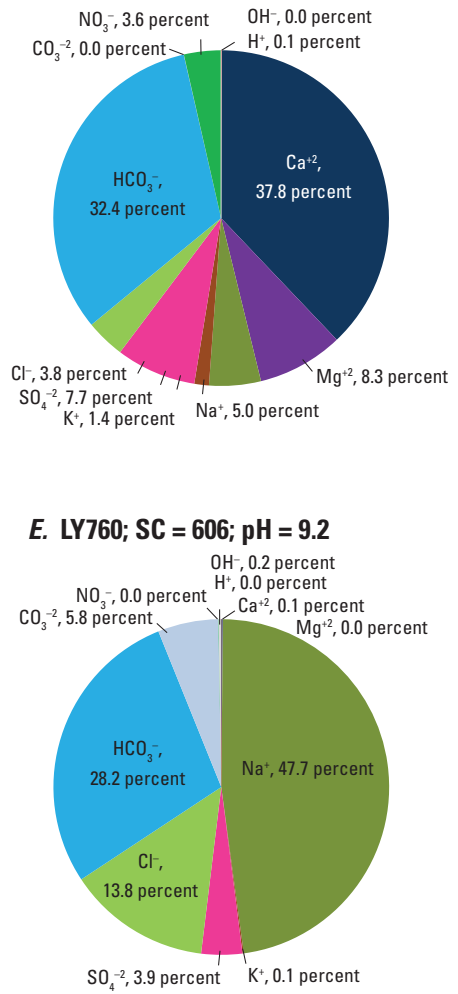

\section{B. $\mathrm{LY} 557 ; \mathrm{SC}=89 ; \mathrm{pH}=5.8$}

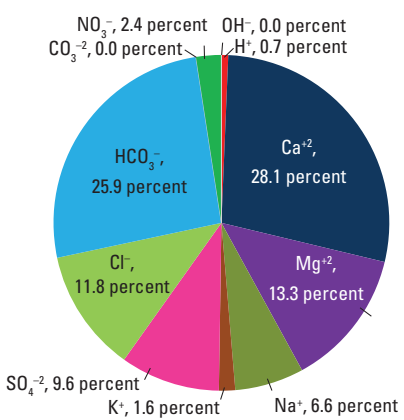

D. $\mathrm{LY} 699 ; \mathrm{SC}=319 ; \mathrm{pH}=7.6$

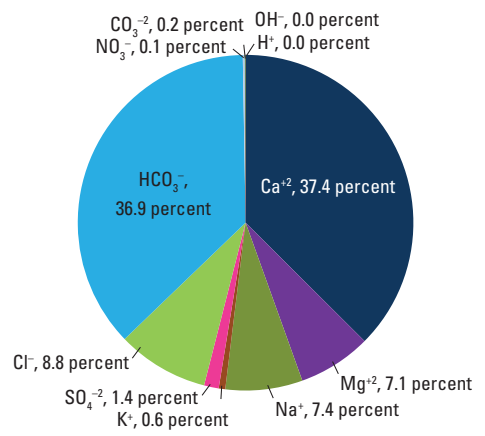

F. $\mathrm{LY} 722 ; \mathrm{SC}=3,120 ; \mathrm{pH}=8.5$

SC, specific conductance, in microsiemens per centimeter at 25 degrees Celsius
Chloride ( $\left.\mathrm{Cl}^{-}\right)$

Bicarbonate $\left(\mathrm{HCO}_{3}^{-}\right)$

Carbonate $\left(\mathrm{CO}_{3}^{-2}\right)$

Nitrate $\left(\mathrm{NO}_{3}^{-}\right)$

Hydroxide $\left(\mathrm{OH}^{-}\right)$

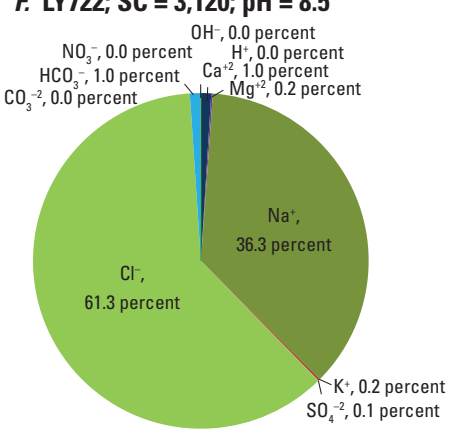

Figure 15. Ionic contributions to specific conductance (SC) computed for selected groundwater samples from Lycoming County, Pennsylvania, 2014 for wells, A, LY718, B, LY557, C, LY732, D, LY699, E, LY760; and F, LY722. Individual ionic conductivities estimated from dissolved constituent concentrations (using methods of McCleskey and others, 2012) after aqueous speciation calculations with the aqueous geochemical computer program, PHREEQC (Parkhurst and Appelo, 2013).

most other samples having low to moderate SC values, such as from wells LY718, LY557, LY732, and LY699, with minor contributions from nitrate, potassium, and hydrogen ions. Samples with higher than average SC values, such as from wells LY760 and LY722, generally have increased contributions from sodium and chloride.

The sample from well LY718 had a pH of 5.3 and SC of $20 \mu \mathrm{S} / \mathrm{cm}$, which were the lowest values for all of the wellwater samples from Lycoming County in 2014. These low $\mathrm{pH}$ and $\mathrm{SC}$ values were comparable to those for bulk precipitation (rainwater) in the northeastern United States (Peters and Bonelli, 1982); the observation that hydrogen protons contributed significantly to the conductivity of this sample is consistent with its acidic $\mathrm{pH}$ and low ionic strength. Samples from wells LY557 and LY732 are representative of minimally evolved groundwater with relatively low, but comparable SC values of 89 and $94 \mu \mathrm{S} / \mathrm{cm}$, respectively. The conductivity of both samples can be produced as the result of rainwater evaporation plus dissolution of various minerals and salts; however, these two samples differ in their ionic character. 
The sample from well LY557 had a pH of 5.8 with important contributions to its conductivity by several ions, including calcium, magnesium, bicarbonate, chloride, and sulfate, and subordinate contributions by sodium, potassium, nitrate, and protons. In contrast, the sample from well LY732 had a higher $\mathrm{pH}$ of 6.8 and ionic conductivity contributions dominated by calcium and bicarbonate, which may reflect the interaction of recharge water or groundwater mainly with calcareous minerals. Although the sample from well LY699 had a higher $\mathrm{pH}$ of 7.6 and SC of $319 \mu \mathrm{S} / \mathrm{cm}$ compared to LY732, both samples would be classified as calcium/bicarbonate water types. In contrast, the sample from well LY760, which had a pH of 9.2 and SC of $606 \mu \mathrm{S} / \mathrm{cm}$, had predominant ionic conductivity contributions by sodium and bicarbonate, with lesser contributions by chloride, carbonate, and sulfate ions. Such sodium/ bicarbonate waters can be produced as a result of cationexchange processes, where sodium on mineral surfaces is exchanged from calcium. In the extreme, the sample from well LY722, which had a pH of 8.5 and the highest measured SC of $3,120 \mu \mathrm{S} / \mathrm{cm}$, had predominant contributions by sodium and chloride, which indicate a salt source. The predominance of sodium and chloride ionic conductivities was exhibited mainly by those samples with elevated SC, but also by a few samples with intermediate $\mathrm{SC}$ values, such as the sample from well LY754, which had a pH of 8.7 and SC of $210 \mu \mathrm{S} / \mathrm{cm}$.

\section{Principal Components Analysis of Interrelations Among Constituents}

Five principal components (PCs) explain nearly 75 percent of the variance in the Lycoming County groundwater dataset and consist of 22 routinely detected constituent loadings (table 8). As explained by Thyne and others (2004), the loading value is comparable to the correlation coefficient between a constituent and the PC, whereas the communality and eigenvalues indicate the degree to which the PCA explains the total variability of the elements considered in the analysis. Associations of additional chemical and physical variables excluded from the analysis are indicated by the Spearman-rank coefficient of correlation of these variables with the PC scores; significant correlations are listed below the five PCAs included in table 8, which are named PC1 through PC5.

PC1, which explains 31.7 percent of the variance in the data, has positive loadings by $\mathrm{pH}$, molybdenum, boron, lithium, sodium, arsenic, strontium, ALK, SC, and bromide, with negative loading by DO and nitrate (table 8). Scores on PC1 are positively correlated with fluoride, TDS (ROE), and gross alpha radioactivity, and negatively correlated with zinc, copper, nickel, and total nitrogen (table 8). The negative associations of $\mathrm{PC} 1$ with $\mathrm{DO}$ and positive associations with $\mathrm{pH}$ and TDS are consistent with the depletion of oxygen as groundwater interacts with organic matter and minerals in the aquifer and becomes more mineralized, alkaline, and "softened" along flow paths from recharge areas in uplands to discharges in valleys. Although PC1 scores were not related to lithology of the source aquifer, those samples classified as anoxic generally had higher, positive scores on PC1 compared to those classified as mixed or oxic, as shown by appendix figure 3-3. High positive scores on PC1 generally may be attributed to the progressive weathering of calcite and dolomite (carbonate minerals) combined with cation-exchange processes. The natural cation-exchange reactions liberate sodium and other alkali earth cations, such as lithium, while removing calcium and magnesium (hardness), much like a water-softening treatment system (Hem, 1985; Poth, 1962). The removal of calcium and magnesium from solution leads to undersaturation of the groundwater with respect to calcite and dolomite, thus promoting additional dissolution of the carbonate minerals and progressive increases in $\mathrm{pH}$ and ALK along the flow path. The resultant sodium-bicarbonate waters tend to have alkaline $\mathrm{pH}$ $(>8)$ values and high positive scores on PC1. At alkaline $\mathrm{pH}$, various trace elements are oxyanions in groundwater, including molybdenum, boron, and arsenic, tend to be poorly sorbed and become mobile; however, trace cations, such as zinc, copper, and nickel, tend to be adsorbed and removed from solution.

PC2, which explains 15.5 percent of the variance in the data, has positive loadings by manganese and iron, and negative loadings by DO, nitrate, radon-222, and arsenic (table 8). Scores on PC2 are positively correlated with ammonia, methane, and fluoride and negatively correlated with total nitrogen, uranium, selenium, lead, and copper. High scores on PC2 are interpreted to indicate isolation from the atmosphere, the depletion of oxygen, and the development of reducing conditions that may be attributed to the microbial decomposition of organic matter in the aquifer or introduced to the groundwater. Samples from aquifers consisting of shale or siltstone lithologies and (or) classified as having anoxic or mixed redox characteristics generally had positive scores on PC2, whereas samples from aquifers consisting of carbonate or sandstone lithologies and (or) classified as oxic generally had negative scores, as shown by appendix figure 3-3. The negative correlation of uranium with PC2 is consistent with its high mobility as uranylcarbonate complexes under oxidizing conditions, whereas the negative correlations of lead, copper, arsenic, selenium, and radon-222 with PC2 indicate decreased mobility of these constituents where concentrations of dissolved iron and manganese are elevated, possibly because of adsorption by hydrous ferric oxide minerals including goethite or ferrihydrite. All but one of the anoxic samples and most of the samples classified as having oxic or mixed redox characteristics are supersaturated or saturated with respect to the hydrous ferric oxide minerals, which is further explained in the "Water Quality Variations and Water-Rock Interactions" section.

PC3, which explains 12.5 percent of the variance in the data, has positive loadings by chloride, strontium, calcium, magnesium, sulfate, ALK, silica, and SC. Scores on PC3 are positively correlated with hardness and TDS. High scores on PC3 can be attributed to the dissolution of calcite, dolomite, gypsum, and possibly pyrite or other sulfide minerals, without the cation-exchange softening effects (alkaline $\mathrm{pH}$ ) indicated by high scores on PC1. Median PC3 scores decreased in the 
Table 8. Principal components analysis of major factors controlling the chemistry of groundwater, Lycoming County, Pennsylvania, 2014.

[--, no data or not applicable; PC1-PC5, Principal components 1 through 5 with major factor indicated in parentheses; Varimax rotation pattern for ranktransformed data (SAS Institute, Inc., 2012); minimum eigenvalue less than 1; loading values for constituents included in model and Spearman correlation coefficients ( $p$-value less than 0.001 ) multiplied by 100 and rounded; *, highly significant loading ( $p$-value less than 0.001 ). Significant Spearman correlation coefficients are shown only for constituents excluded from the principal components analysis]

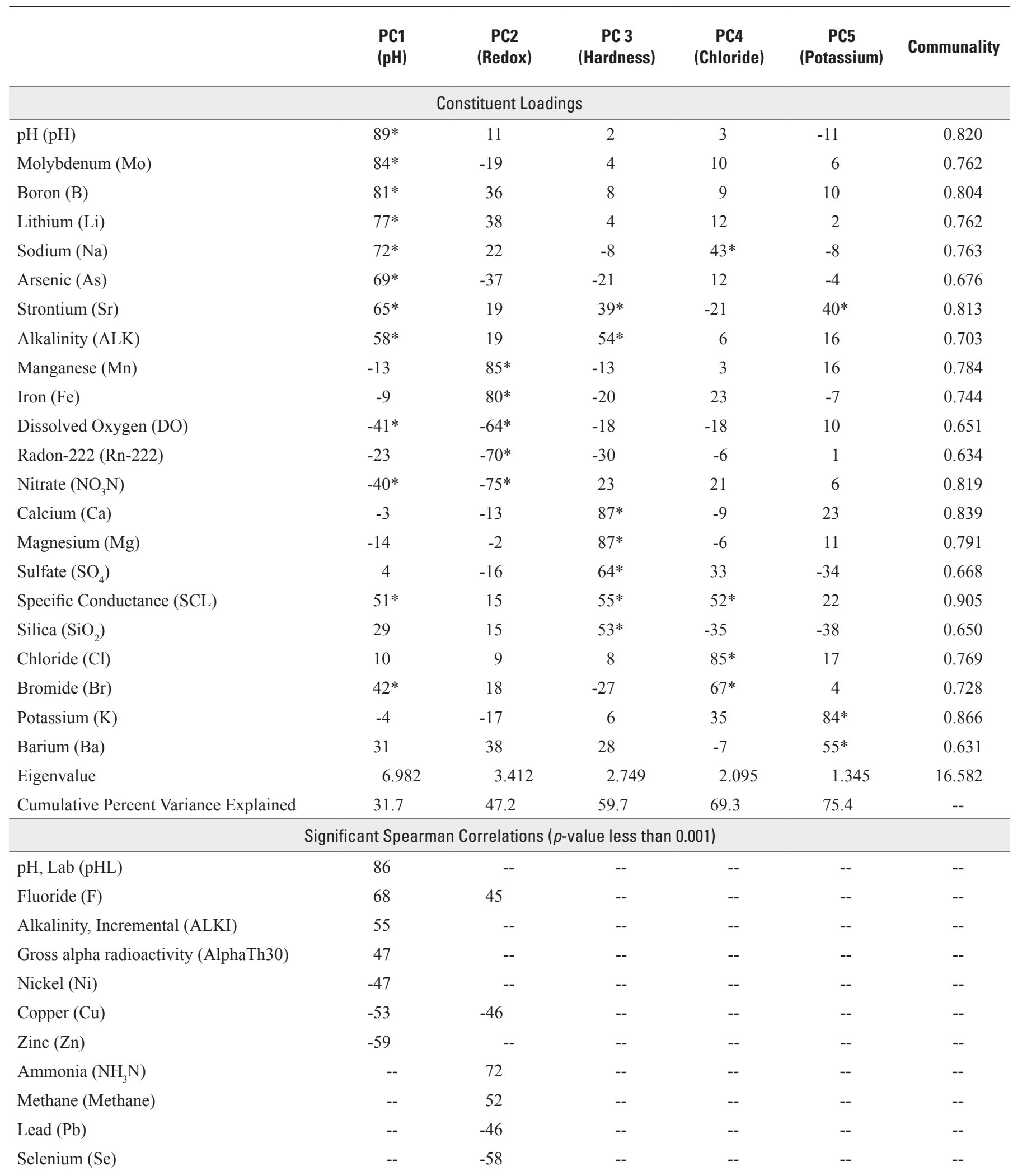


Table 8. Principal components analysis of major factors controlling the chemistry of groundwater, Lycoming County, Pennsylvania, 2014.-Continued

[--, no data or not applicable; PC1-PC5, Principal components 1 through 5 with major factor indicated in parentheses; Varimax rotation pattern for ranktransformed data (SAS Institute, Inc., 2012); minimum eigenvalue less than 1; loading values for constituents included in model and Spearman correlation coefficients ( $p$-value less than 0.001 ) multiplied by 100 and rounded; $*$, highly significant loading ( $p$-value less than 0.001$)$. Significant Spearman correlation coefficients are shown only for constituents excluded from the principal components analysis]

\begin{tabular}{|c|c|c|c|c|c|c|}
\hline Uranium (U) & -- & -70 & -- & -- & -- & -- \\
\hline Hardness (Hard) & -- & -- & 93 & -- & -- & -- \\
\hline Specific Conductance, Field (SCF) & 48 & -- & 52 & 51 & -- & -- \\
\hline Residue on Evaporation 180C (ROE180) & 44 & -- & 52 & 51 & -- & -- \\
\hline
\end{tabular}

order of carbonate, shale, siltstone, and sandstone lithologies, as shown by appendix figure 3-4.

PC4, which explains 9.6 percent of the variance in the data, has positive loadings by chloride, bromide, sodium, and $\mathrm{SC}$ and is positively correlated with TDS (table 8). The positive association between chloride, bromide, and sodium could indicate the influence of Appalachian Basin brine or other sources of salinity, such as sewage, fertilizer, and (or) roaddeicing salt, on the groundwater of associated samples.

PC5, which explains 6.1 percent of the variance in the data, has positive loadings by potassium, barium, and strontium (table 8). The positive associations of these cations could indicate a common origin or geochemical control. For example, potassium, barium, and strontium commonly substitute for calcium in carbonate (aragonite) minerals and one another in sulfate (barite-celestine) minerals, which could be possible sources or sinks of the cations (Hanor, 1968; Hanshaw and Back, 1979). Additionally, these cations may be retained more strongly than sodium and lithium by clay minerals involved in cation-exchange (Appelo and Postma, 2005) and, thus, may be released as the exchange sites become depleted in sodium and lithium and enriched in calcium and magnesium.

\section{Relation Between Groundwater Quality, Geology, and Topographic Setting}

Groundwater acquires solutes through natural and anthropogenic loading of constituents in the recharge area from precipitation, weathering reactions of minerals in the soil and aquifer materials, and constituents applied by human activities at or near the land surface. Additional solutes may be acquired as groundwater flows through the aquifer. Groundwater supplying most domestic wells completed in shallow fractured bedrock aquifers is derived principally from local recharge and will be influenced by land use and geology near the well.
Bedrock underlying Lycoming County mainly consists of clastic sedimentary lithologies that include shale, siltstone, and sandstone. Such clastic rocks mainly consist of silicate and aluminosilicate minerals, including quartz, feldspar, chlorite, muscovite, and illite, plus minor carbonate, sulfate, sulfide, and oxide minerals that are clasts, fracture filling, and cements. Geologic units with primarily carbonate lithologies, such as limestone and calcareous shale, are present in the southern part of the county (fig. 3), but only three wells in this study were completed in carbonate rock units.

The constituent concentrations for the four major lithologic classes, defined as carbonate, shale, siltstone, and sandstone, generally had comparable ranges (fig. 3-4). Although most constituent concentrations varied little with lithologic class, the medians for several constituents were significantly different between the carbonate and siliciclastic lithologies. The samples associated with carbonate bedrock had higher median values for SC, TDS, hardness, calcium, magnesium, potassium, ALK, sulfate, chloride, and nitrate, and lower median values for bromide, boron, methane, aluminum, orthophosphate, and arsenic than the samples from siliciclastic bedrock lithologies. Furthermore, the samples from carbonate and sandstone bedrock had higher median values for uranium and radon-222 than those from shale and siltstone lithologies.

Although mineralogy is expected to vary locally, the carbonate, sulfate, and sulfide minerals in the siliciclastic bedrock are prone to weathering in near-surface environments where they may be important sources of hardness, ALK, sulfate, and other solutes. Likewise, various clay minerals, which are hydrated aluminosilicates with layered crystal structures that readily accommodate ionic substitutions, are widely recognized to be involved in cation-exchange and sorption processes (Hem, 1985; Appelo and Postma, 2005). For example, chlorite, muscovite, illite, and kaolinite are common clay components of soils, shales, and siltstones and could influence solute concentrations in well-water samples from the study area. 


\section{Major Ion Compositions Indic ated by Piper Diagrams}

Trilinear diagrams and associated Piper diagrams indicate the percentage contributions of the major cations and anions, in equivalents (molar concentration multiplied by ionic charge), relative to the total equivalents for cations and anions in a sample. Although similar in concept to the pie charts showing ionic conductivity contributions to the SC, the factors used to compute the equivalents do not consider ion size and mobility, which are incorporated with the transport numbers for ionic conductivity (giving somewhat different ionic proportions). The corresponding "water type" is identified on the basis of the predominant (greater than 50 percent) cation(s) and anion(s) shown on the trilinear diagrams (fig. 16). For the Lycoming County well-water samples, calcium/bicarbonate type waters were most abundant, with others classified as sodium/bicarbonate or mixed water types including calciumsodium/bicarbonate, calcium-sodium/bicarbonate-chloride, sodium/bicarbonate-chloride, or sodium/chloride types (fig. 16).

Representative samples are identified on the Piper diagram in fig. $17 A$ and $B$ in order to explain their characteristics and possible origins. The sample from well LY557 is the low$\mathrm{pH}$, low ionic strength sample, described previously, which is similar in character to rainwater. Samples from wells LY732, LY721, and LY699 are classified as calcium/bicarbonate type, and samples from wells LY432 and LY718 are calcium-magnesium/bicarbonate type (fig. 17A), which can be produced by the dissolution of calcium carbonate and dolomite by rainwater (recharge) or groundwater (fig. 17B). Samples from wells LY700, LY755, LY703, and LY760 are classified as sodium/ bicarbonate type. Such water types are likely to form by the dissolution of calcite and (or) dolomite combined with cationexchange; these processes are described in more detail below. Samples plotting away from an apex or within the center part of the diagram are classified as mixed hydrochemical types. For example, the sample from well LY716 is classified as a mixed calcium/bicarbonate-chloride type, the sample from well LY719 is classified as a mixed sodium-calcium/bicarbonate-chloride type, and the sample from well LY731 is a mixed calcium-sodium/chloride-bicarbonate type. The mixed water types imply that multiple sources of constituents or processes may be important. Finally, samples from wells LY781, LY735, and LY722 are sodium-chloride type. The predominance of chloride implies the addition of salt (sodium chloride, calcium chloride) from road-deicing salts, sewage or animal waste, or possibly brine of geological origin.

As illustrated in figure $17 B$, possible evolution pathways are indicated for the various well-water samples. The dissolution of calcite by groundwater produces calcium/bicarbonate type (on the left corner of the Piper diagram). Calcite dissolution combined with cation-exchange produces the sodium/ bicarbonate type (on the lower corner). Simple mixing of calcium/bicarbonate water with brine can explain waters of mixed calcium-sodium/bicarbonate-chloride types (upper right track). Likewise, the addition of road-deicing salt to groundwater produces a range of mixed calcium-sodium/bicarbonatechloride to sodium/chloride water types (ending on the right corner); however, the sodium/chloride type (right corner) also can be produced by mixing of groundwater with brine plus cation-exchange, with or without calcite dissolution. Although the origins and evolution pathways are very different, the points on a Piper diagram cannot be distinguished. Other characteristics, such as the $\mathrm{pH}$, ionic strength, and the concentrations of bromide, lithium, strontium, and barium, could be helpful to distinguish the origins of the groundwater.

\section{Water-Quality Variations and Water-Rock Interactions}

To evaluate the potential for various minerals to be dissolved or precipitated by the groundwater, the SI values are displayed as a function of $\mathrm{pH}$ for the Lycoming County well-water samples (fig. 18). The samples that had $\mathrm{pH} \leq 8$ were undersaturated $(\mathrm{SI}<0)$ with respect to calcium carbonate and dolomite, indicating the groundwater could feasibly dissolve these carbonate minerals, if present. The $\mathrm{SI}_{\mathrm{CAL}}$ increased linearly from $\mathrm{pH}$ of 5.3 (SI -4.99) to $\mathrm{pH}$ of 8 (SI -0.04), above which the SI value approximately equal to 0 was maintained. Despite the indicated equilibrium, dissolution of calcite could be anticipated to continue at $\mathrm{pH}$ values greater than 8 because of the removal of calcium in exchange of sodium. As the concentrations of calcium are depleted, the groundwater could dissolve more calcite with progressive increases in concentrations of ALK and $\mathrm{pH}$ to values as high as 9.2 (fig. 13).

On the basis of negative SI values, feldspar minerals, represented by albite, were undersaturated and could feasibly dissolve in groundwater, albeit slowly. In addition to being sources of base cations (sodium, potassium, calcium), aluminum, and silicon, the feldspars commonly contain traces of phosphate and, thus, could be a potential natural source of phosphate in the sampled groundwater (Denver and others, 2010). Likewise, chlorite, which is a clay mineral, was indicated to be undersaturated and unstable. In contrast, quartz and kaolinite were saturated or supersaturated. Thus, over the range of $\mathrm{pH}$ for the samples of this study, the unstable aluminosilicates generally would be anticipated to dissolve incongruently, releasing cations to solution while silica and aluminum are retained in secondary solid phases, such as quartz and kaolinite. Other clay minerals, including beidellite, illite, and muscovite had SI values that ranged from negative to positive, indicating these or similar phases could potentially decompose where undersaturated, or such phases could participate in surface complexation or exchange reactions where saturated or supersaturated.

The major calcium and magnesium carbonate minerals commonly contain traces of other cations, including iron, manganese, strontium, and barium (Hanshaw and Back, 1979). These trace cations can also appear locally as pure carbonate phases. Over the range of $\mathrm{pH}$, the SI values for siderite, 


\section{A. Water type or hydrochemical facies}

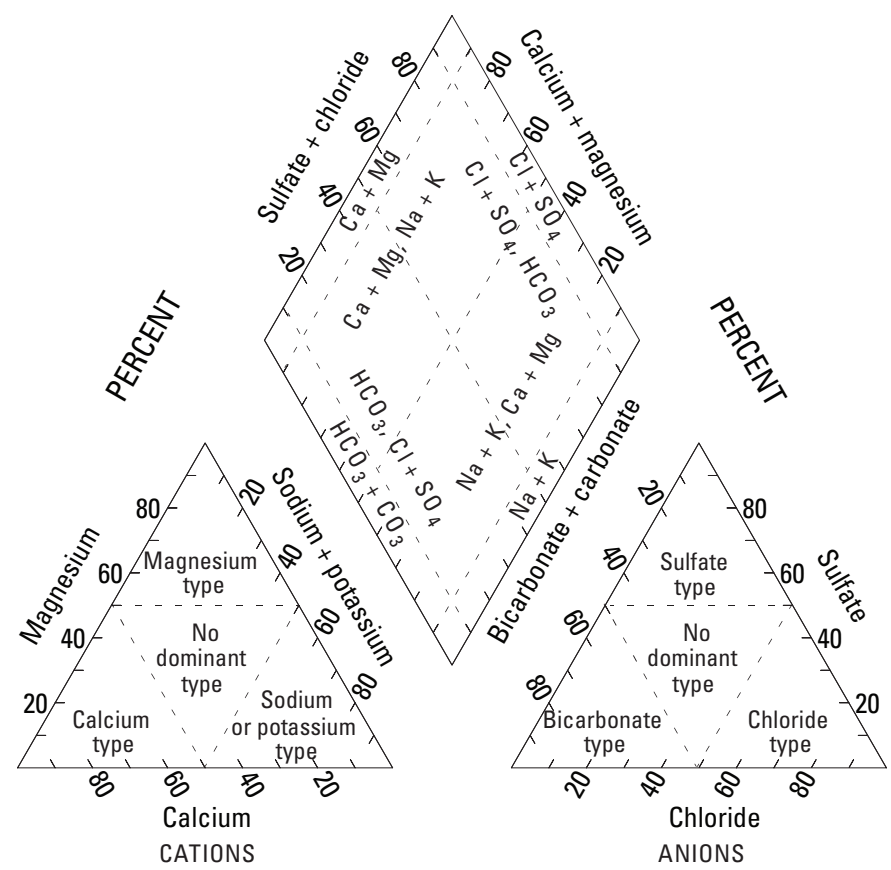

PERCENTAGE OF TOTAL MILLIEQUIVALENTS PER LITER

\section{B. Lycoming County groundwater 2014}

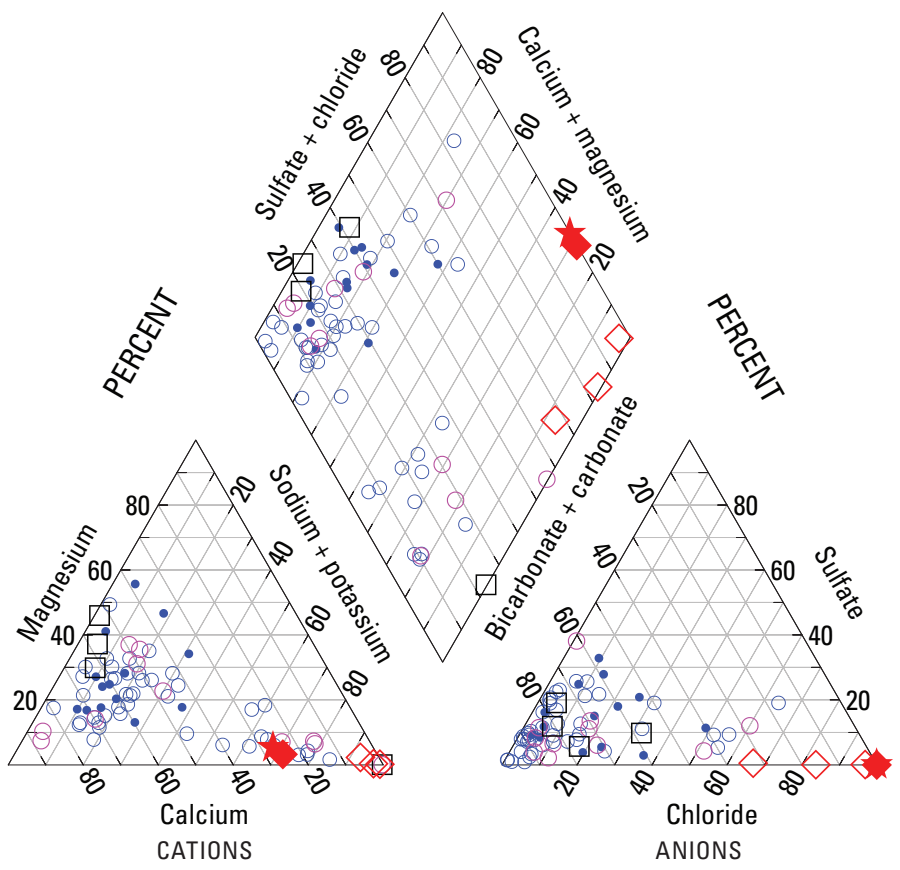

PERCENTAGE OF TOTAL MILLIEQUIVALENTS PER LITER

\section{EXPLANATION}

\begin{tabular}{|c|c|c|}
\hline & & Groundwater \\
\hline Hydrogen $\left(\mathrm{H}^{+}\right)$ & - & $20<\mathrm{SC}<150$ \\
\hline Calcium $\left(\mathrm{Ca}^{+2}\right)$ & 0 & $150 \leq \mathrm{SC}<300$ \\
\hline Magnesium $\left(\mathbf{M a}^{+2}\right)$ & $\mathrm{O}$ & $300 \leq \mathrm{SC}<500$ \\
\hline ivagnesicuming & $\square$ & $500 \leq \mathrm{SC}<700$ \\
\hline Sodium $\left(\mathrm{Na}^{+}\right)$ & & $700 \leq \mathrm{SC}<3,120$ \\
\hline Potassium $\left(\mathbf{K}^{+}\right)$ & t & Oil and gas well brine \\
\hline Sulfate $\left(\mathrm{SO}_{4}{ }^{-2}\right)$ & & Flowback water \\
\hline Chloride $\left(\mathrm{Cl}^{-}\right)$ & SC & $\begin{array}{l}\text { Specific conductance, } \\
\text { in microsiemens per centimeter }\end{array}$ \\
\hline Bicarbonate $\left(\mathrm{HCO}_{3}^{-}\right)$ & $<$ & Less than \\
\hline Carbonate $\left(\mathrm{CO}_{3}^{-2}\right)$ & $\leq$ & Less than or equal to \\
\hline
\end{tabular}

Figure 16. Trilinear diagrams showing $A$, predominant water types or hydrochemical facies; and $B$, data for groundwater samples collected from 75 wells in Lycoming County, Pennsylvania, 2014, plus median composition of brine from oil and gas wells in western Pennsylvania (Dresel and Rose, 2010) and flowback water from Marcellus Shale gas wells (Hayes, 2009). Symbols for groundwater scaled by specific conductance. 


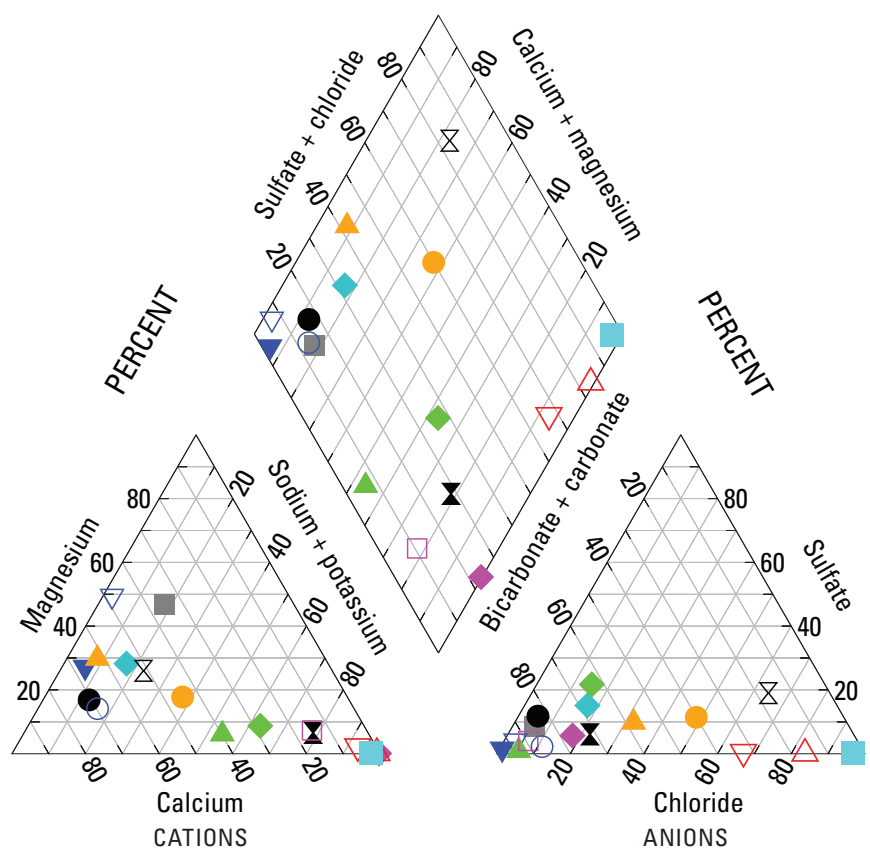

PERCENTAGE OF TOTAL MILLIEQUIVALENTS PER LITER



PERCENTAGE OF TOTAL MILLIEQUIVALENTS PER LITER
EXPLANATION

Groundwater sample number
LY718
LY732
LY557
$\nabla$ LY721
$\nabla$ LY432
$\bigcirc$ LY432
X LY749
$\triangle \mathrm{LY} 700$
$\checkmark$ LY719
X $\llcorner Y 703$
LY731
$\triangle$ LY716
$\square \mathrm{LY755}$
LY760
$\nabla$ LY781
$\triangle$ LY735
LY722

\section{EXPLANATION}

Groundwater plus calcite

Groundwater plus calcite plus exchange

$>$ Groundwater plus road salt

Groundwater plus brine

$\triangle$ Groundwater plus brine plus exchange

$\nabla$ Groundwater plus brine plus calcite plus exchange

Figure 17. Trilinear diagrams showing $A$, data for 17 selected groundwater samples from Lycoming County, Pennsylvania, 2014; and $B$, evolution pathways for mixing of dilute calcium/bicarbonate groundwater with road-deicing salt, with brine, with brine combined with cation-exchange, or with brine plus calcite dissolution to saturation and then cation-exchange. Evolution pathways computed for groundwater sample LY557 mixed in varying proportions with median composition for brine and for the same initial groundwater sample with varying amounts of road-deicing salt. 


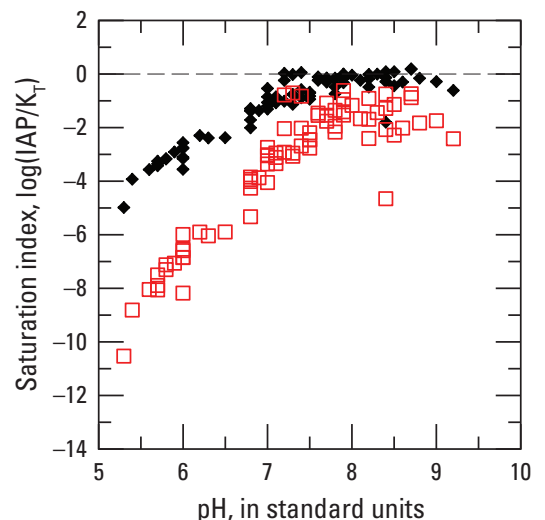

EXPLANATION

- Calcite- $\mathrm{CaCO}_{3}$

$\square$ Dolomite- $\mathrm{CaMg}\left(\mathrm{CO}_{3}\right)_{2}$

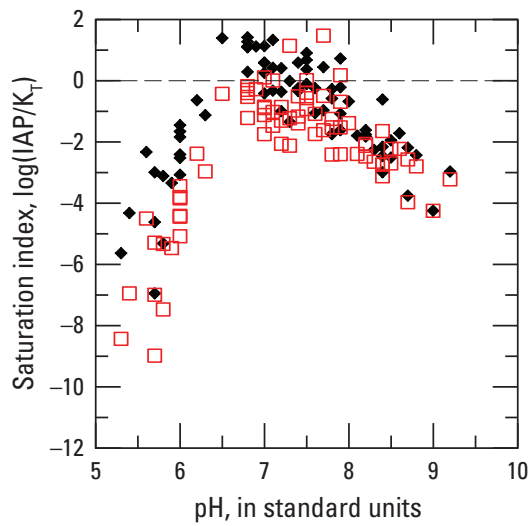

EXPLANATION

- Beidellite- $\left(\mathrm{NaKMg}_{0.5}\right)_{0.11} \mathrm{Al}_{2.33} \mathrm{Si}_{3.67} \mathrm{O}_{10}(\mathrm{OH})_{2}$

$\square$ Illite $-\mathrm{K}_{0.6} \mathrm{Mg}_{0.25} \mathrm{Al}_{2.3} \mathrm{Si}_{3.5} \mathbf{O}_{10}(\mathrm{OH})_{2}$



EXPLANATION

- Manganite-MnOOH

$\square$ Rhodochrosite- $\mathrm{MnCO}_{3}$

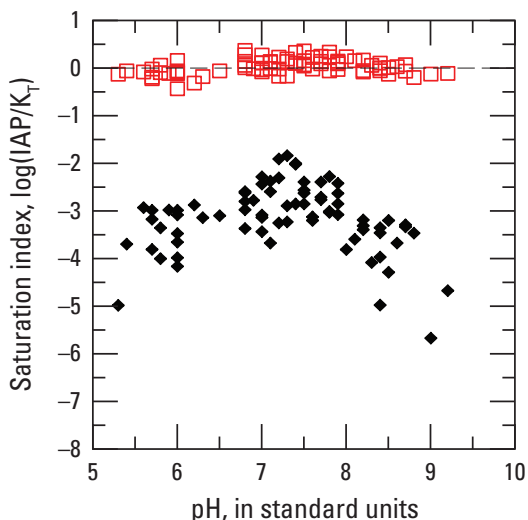

EXPLANATION

- Gypsum- $\mathrm{CaSO}_{4} \cdot 2 \mathrm{H}_{2} \mathrm{O}$

$\square$ Quartz- $\mathrm{SiO}_{2}$

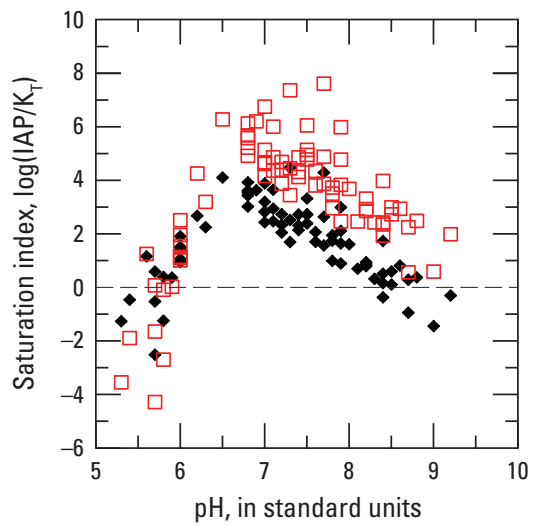

EXPLANATION

- Kaolinite- $\mathrm{Al}_{2} \mathrm{Si}_{2}$ 05(OH)

$\square$ Muscovite- $-\mathrm{KAl}_{3} \mathrm{Si}_{3} \mathrm{O}_{10}(\mathrm{OH})_{2}$

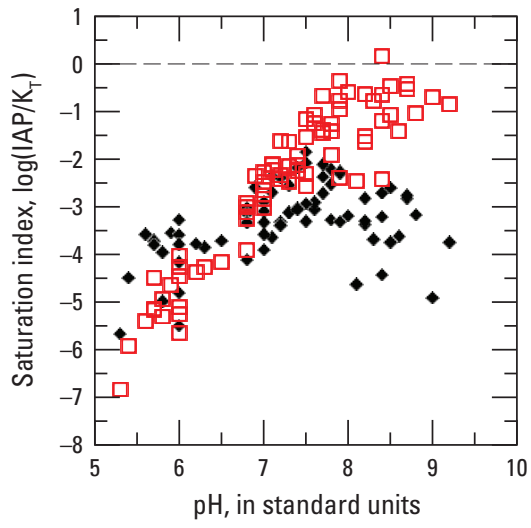

EXPLANATION

- Celestine- $\mathrm{SrSO}_{4}$

$\square$ Strontianite- $\mathrm{SrCO}_{3}$

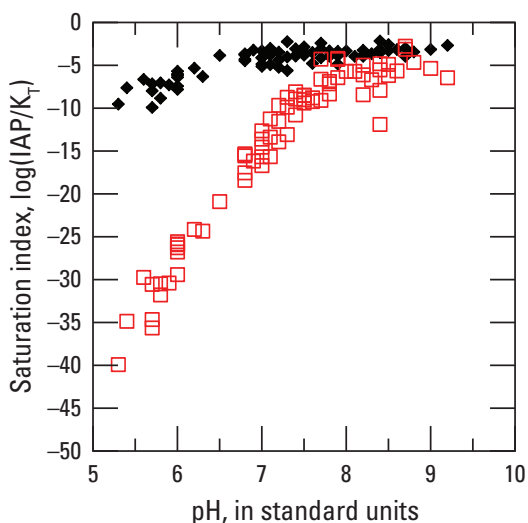

EXPLANATION

- Albite- $\mathrm{NaAlSi}_{3} \mathrm{O}_{8}$

$\square$ Chlorite- $\mathrm{Mg}_{5} \mathrm{Al}_{2} \mathrm{Si}_{3} \mathrm{O}_{10}(\mathrm{OH})_{8}$

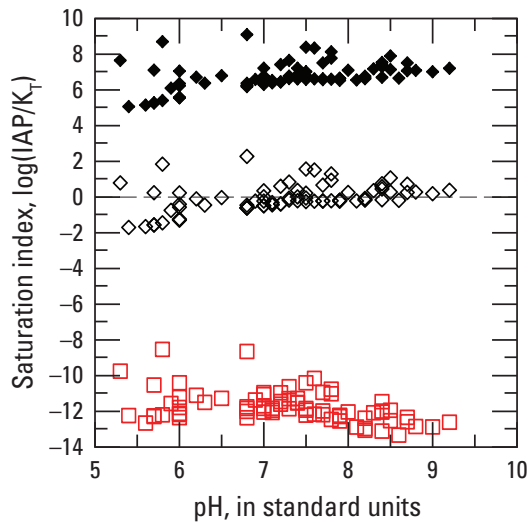

EXPLANATION

- Goethite-Fe00H

$\diamond \mathrm{Fe}(\mathrm{OH})_{3}(\mathrm{a})-\mathrm{Fe}(\mathrm{OH})_{3}$

$\square$ Siderite- $-\mathrm{FeCO}_{3}$

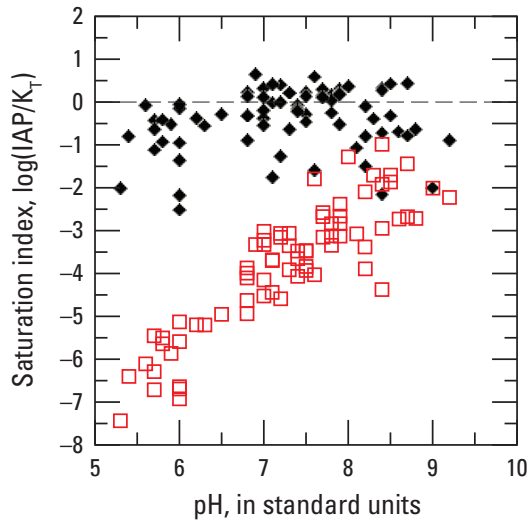

EXPLANATION

- Barite- $\mathrm{BaSO}_{4}$

$\square$ Witherite- $\mathrm{BaCO}_{3}$

Figure 18. Saturation indices for minerals and other solids as a function of $\mathrm{pH}$ for groundwater samples collected from 75 wells in Lycoming County, Pennsylvania, 2014. Computations with PHREEQC aqueous geochemical computer program (Parkhurst and Appelo, 2013) using the wateq4f.dat database file derived from the WATEQ4F ion-association aqueous model (Ball and Nordstrom, 1991). [IAP, Ion Activity Product; $\mathrm{K}_{\mathrm{T}}$, equilibrium constant for reaction at temperature T] 
rhodochrosite, strontianite, and witherite were negative, indicating these carbonate minerals, if present, could feasibly be dissolved by the groundwater (fig. 18). Hence, dissolution of calcite, dolomite, or other carbonates could release various trace cations to solution. However, the concentrations of trace elements may be limited by the formation of other solid phases. For example, the accumulation of sulfate from rainfall, sulfide mineral oxidation, or gypsum dissolution could promote the observed supersaturation of barite, which could precipitate and limit the concentrations of dissolved barium (fig. 18). In contrast, celestine was indicated to be undersaturated (fig. 18). Nevertheless, strontium concentrations could possibly be limited by coprecipitation with barium in barite (Hanor, 1968). Furthermore, strontium, barium, and other trace cations could participate in exchange reactions with clay minerals or adsorption processes.

Hydrous oxides of iron and manganese are common in soils and weathered bedrock. The groundwater sampled for the study generally is indicated to be saturated or supersaturated with respect to iron and manganese oxides, which indicates such phases could feasibly precipitate as stable secondary phases (although the redox state is uncertain) upon dissolution of carbonates or oxidation of sulfides containing iron and manganese. The hydrous iron and manganese oxides are widely recognized as potential sorbents of trace anions (arsenic, selenium, molybdenum, and boron) at acidic $\mathrm{pH}$ and cations (copper, lead, and zinc) at near-neutral to alkaline $\mathrm{pH}$ (Appelo and Postma, 2005; Dzombak and Morel, 1990; Hem, 1985). Adsorption, or surface complexation, can maintain trace-element concentrations at low levels compared to the solubilities of corresponding trace-element minerals; however, as the $\mathrm{pH}$ or redox conditions change, the trace ions could be released into solution by the oxides (Chapman and others, 2012). An illustration of the effects of changes in $\mathrm{pH}$ on the potential for adsorption and desorption of trace elements by hydrous iron oxide, or hydrous ferric oxide, is shown in figure 19. Hydrous ferric oxide was specified as $90 \mathrm{mg} / \mathrm{L}$, with a specific surface area of 600 square meters per gram consisting of $5 \times 10^{-6}$ moles of strong binding sites and $2 \times 10^{-4}$ moles of weak binding sites. Relevant anion or cation was specified as 0.05 millimole per liter $(\mathrm{mmol} / \mathrm{L})$ in matrix consisting of $5 \mathrm{mmol} / \mathrm{L}$ chloride, sulfate, and dissolved inorganic carbon plus sodium to balance charge.

\section{Chloride, Bromide, and Sodium in Groundwater}

The concentrations of chloride ( 0.5 to $938 \mathrm{mg} / \mathrm{L})$, bromide $(<0.03$ to $2.71 \mathrm{mg} / \mathrm{L})$, and sodium $(0.5$ to $609 \mathrm{mg} / \mathrm{L})$ for the 75 groundwater samples collected for this study ranged widely and were positively correlated with one another. In Lycoming County, chloride concentrations greater than a few $\mathrm{mg} / \mathrm{L}$ in shallow groundwater may result from human activities or contributions from naturally present, deeper, more saline groundwater of regional extent. The elevated chloride concentrations may be associated with elevated concentrations of sodium and, in some cases, nitrate and sulfate, which could indicate influence from human or animal waste. Elevated concentrations of chloride also may be associated with elevated (but two or more orders of magnitude smaller) concentrations of bromide, which could indicate influence from residual brine of geologic origin.

Chloride/bromide ratios can be useful to distinguish different sources of chloride (Davis and others, 1998; Mullaney and others, 2009; Whittemore, 2007). Bromide, like chloride, is a soluble anion that exhibits conservative transport properties and can be used as a tracer, if present at detectable concentrations. Some sources of chloride introduced by human activities into the environment, such as road-deicing salt (sodium chloride) or salt present in septic effluent, typically have low amounts of bromide and relatively high chloride/bromide mass ratios. Recent studies of groundwater quality in nearby Susquehanna County in northeastern Pennsylvania (Warner and others, 2012; Llewellyn, 2014; Siegel and others, 2015) have reported groundwater that has concentrations of chloride and chloride/ bromide ratios that indicate possible mixing with higher salinity or brine-type waters; these brine-type waters are postulated to be discharging from undetermined depths below the freshwater aquifer and mixing with shallow, more dilute groundwater (fig. 12).

The chloride/bromide mass ratios for the 75 Lycoming County well-water samples are shown in relation to chloride concentrations in figures $20 \mathrm{~A}$ and $20 \mathrm{~B}$, which also show curves representing compositions resulting from mixing of different proportions of dilute groundwater with (1) relatively pure sodium chloride salt containing only a trace of bromide (such as road-deicing salt, salt in water softeners, and salt present in human and animal waste) or (2) bromide-rich oil and gas well brines (such as that from wells producing gas from the Marcellus Shale). Most of the Lycoming County well-water samples, including the sample with the highest chloride concentration (from well LY722) of $938 \mathrm{mg} / \mathrm{L}$, plotted on or near the mixing curve for relatively pure sodium chloride salt; however, several well-water samples (from wells LY760, LY384, LY781, and LY735) had relatively high bromide concentrations (greater than $0.1 \mathrm{mg} / \mathrm{L}$ ) with low chloride/bromide mass ratios (about 120 to $150 \mathrm{mg} / \mathrm{L}$ ) compared to their chloride concentrations of $20 \mathrm{mg} / \mathrm{L}$ and higher (fig. 20). These well-water samples plotted near or on the mixing curve for oil and gas well brines (figs. 20A, $B$, and $C$ ), indicating a possible small contribution of chloride from a brine-like source. Salt Spring, a natural saline spring in Susquehanna County, also plotted along the brine mixing curve. Mixing curves computed for initial fresh water with chloride of 0.5 to $0.6 \mathrm{mg} / \mathrm{L}$ and bromide of 0.025 to $0.035 \mathrm{mg} / \mathrm{L}$ mixed with road-deicing salt (fig. 20 upper curve, after Llewellyn, 2014) or with median composition of oil and gas well brine (fig. 20 lower curve, after Dresel and Rose, 2010). Selected samples having methane concentrations $\geq 0.7 \mathrm{mg} / \mathrm{L}$, alkaline $\mathrm{pH}$, or other chemical characteristics illustrate the variable compositions of the samples from Lycoming County, Pennsylvania (fig. 20). 

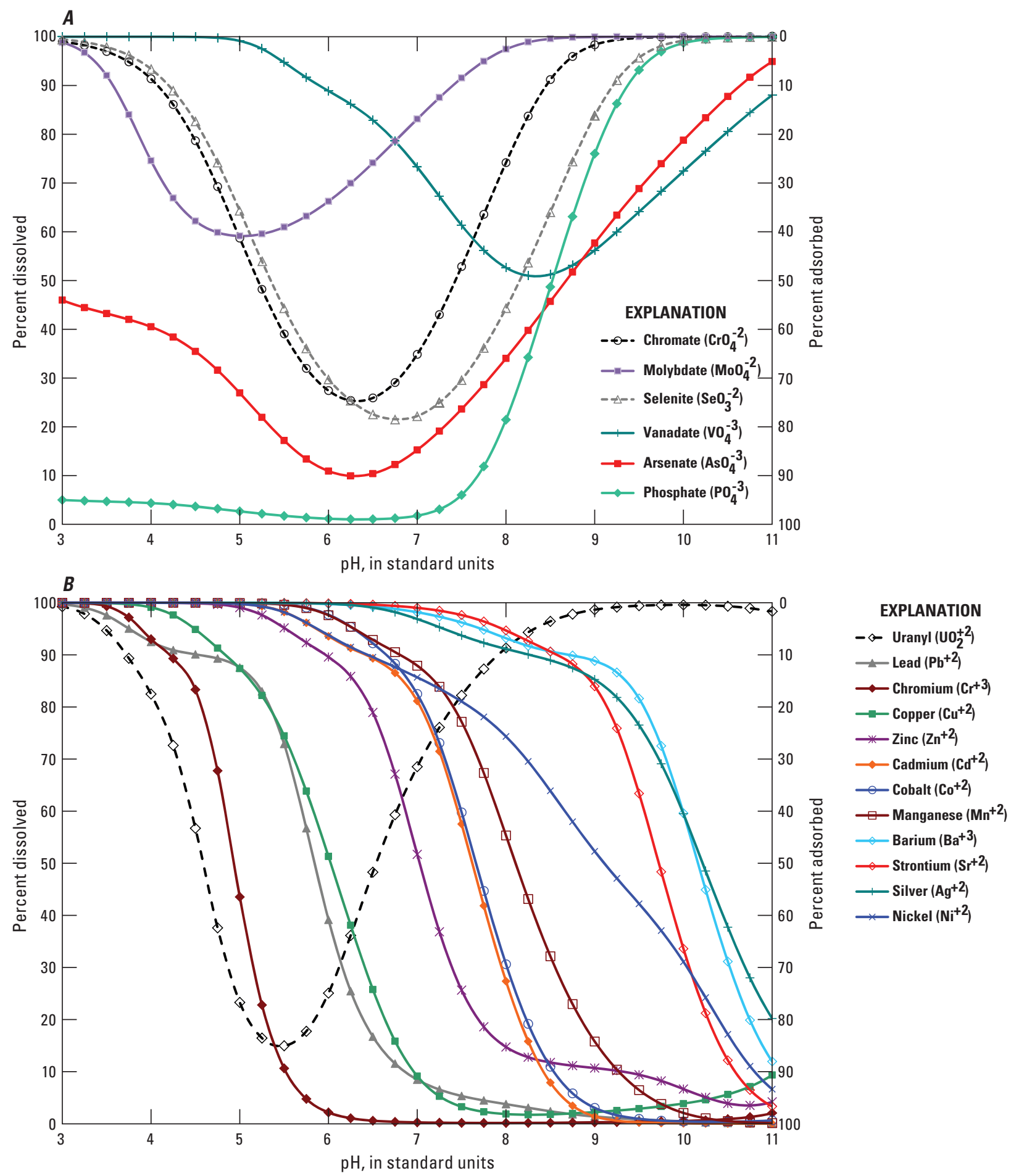

Figure 19. Equilibrium fractions of initial concentrations of $A$, anions or $B$, cations that may be dissolved or adsorbed on a finite amount of hydrous ferric oxide at 25 degrees Celsius as a function of $\mathrm{pH}$. Area below curve indicates fraction that is not adsorbed; area above curve indicates fraction adsorbed. Simulations conducted using PHREEOC aqueous geochemical modeling program (Parkhurst and Appelo, 2013) with thermodynamic data from Ball and Nordstrom (1991), Duro and others (2012), and Dzombak and Morel (1990). 


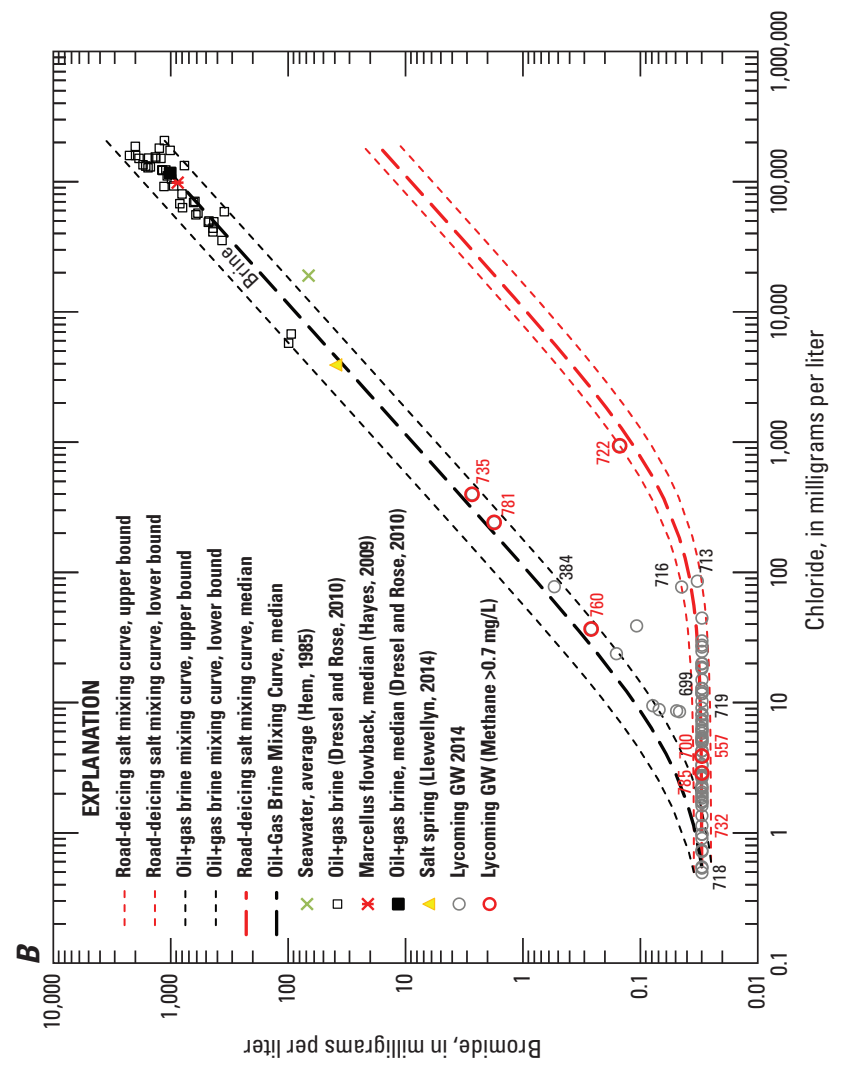

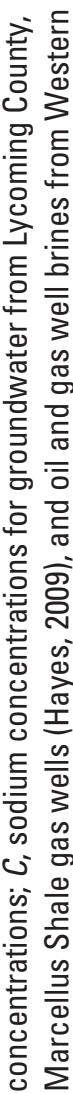

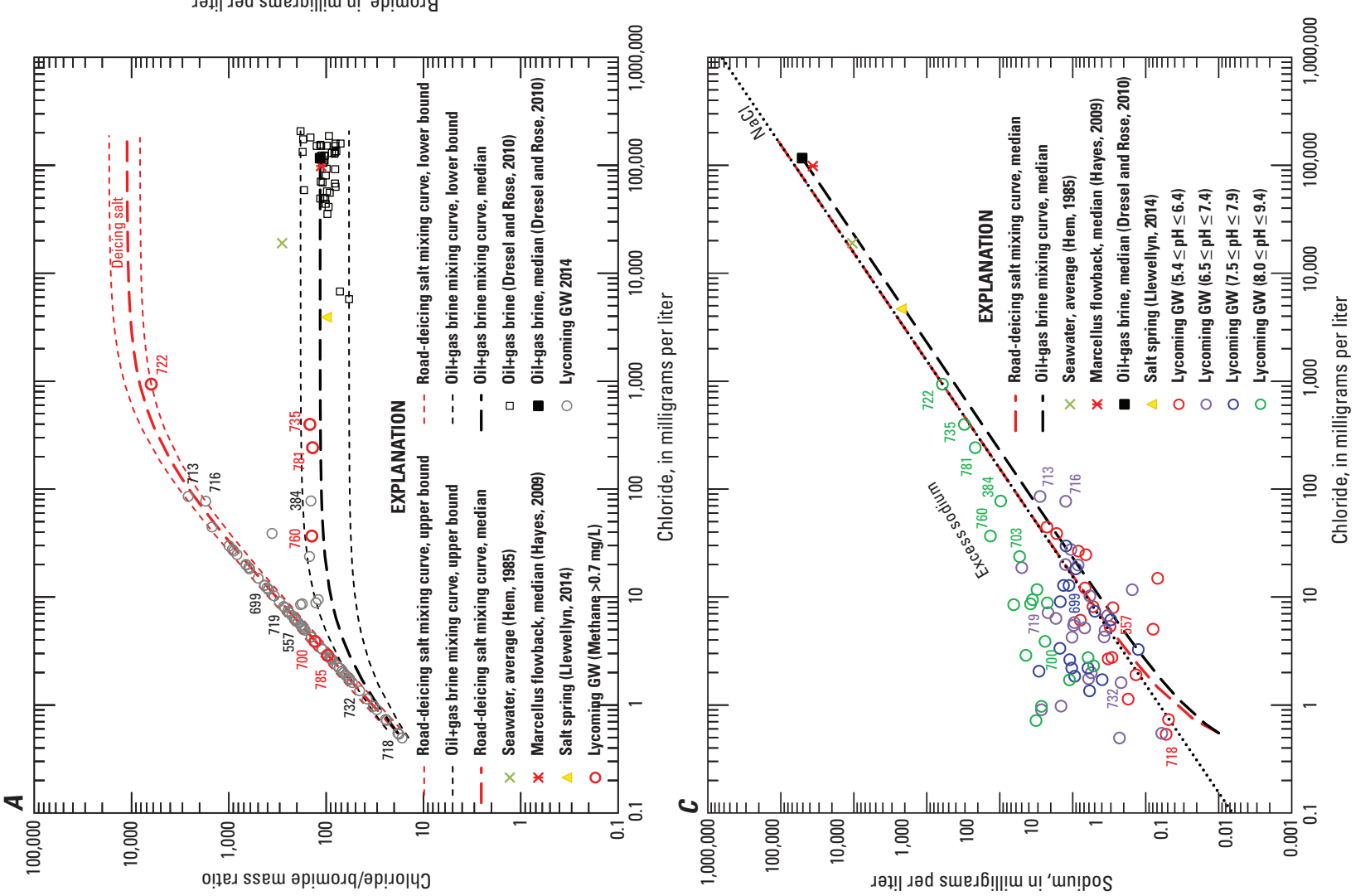

을 흥

空

흘

$\infty 0^{\circ}$

is

중

定

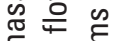

$\varepsilon$ 政

응 홀

ह

은

के

은 웡트

흘 흘

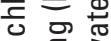

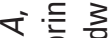

응

表

怘

흘

잉

음음

을 구

荧 要

잉

도

늠

응

흗 六

.

ลิ่

ปู่ के 
Of the six water samples that had methane concentrations $\geq 0.7 \mathrm{mg} / \mathrm{L}$, three samples (from wells LY785, LY700, and LY722) had chloride/bromide ratios that plotted on the road-deicing salt mixing curve, whereas the remaining samples (from wells LY735, LY781, and LY760) had chloride/bromide mass ratios that plotted on the brine mixing curve (figs. 20A-C). These six wells were located in valleys or on valley sides and had depths ranging from 149 to 500 feet below the land surface. Nevertheless, many other wells in the valley settings did not exhibit elevated methane concentrations.

Most of the samples had chloride/bromide ratios that plotted along the mixing curve for road-deicing salt, which is essentially sodium chloride that is also present in human and animal waste. For example, the water sample from well LY722, which had the highest concentration of chloride $(938 \mathrm{mg} / \mathrm{L}=26.5 \mathrm{mmol} / \mathrm{L})$, had an equal molar concentration of sodium $(609 \mathrm{mg} / \mathrm{L}=26.5 \mathrm{mmol} / \mathrm{L})$, which could result by the dissolution of pure sodium chloride by groundwater or recharge water (fig. 20C). Nevertheless, compared to the stoichiometry for sodium chloride, many other samples that had chloride and bromide compositions plotting on the chloride/bromide mixing curve for salt also contained excess sodium (greater than 1:1 [sodium]:[chloride] molar ratio or 22.99:35.45 mass ratio). The excess sodium, which can be derived from mineral sources that do not contain chloride, may result from the release of residual sodium on cation-exchange sites on clay minerals to the groundwater.

The chloride/bromide and associated constituent relations for the Lycoming County well-water samples collected for this study are similar to those for 20 groundwater samples collected in 2012 in Sullivan County (Sloto, 2013), 20 groundwater samples collected in 2012 in Pike County (Senior, 2014), and 121 groundwater samples collected in 2013-14 in Wayne County (Senior and others, 2016). These studies consistently indicate that groundwater in north-central and northeastern Pennsylvania has locally elevated concentrations of bromide, chloride, sodium, and methane.

\section{Geochemical Models}

The evolution pathways for the major ions indicated on the Piper diagram (fig. 17) and also as mixing curves on the bromide/chloride and sodium/chloride plots (fig. 20) were computed using the PHREEQC aqueous geochemical computer program to create geochemical models considering the various mixing scenarios with road-deicing salt or brine, plus reactions including calcite dissolution and (or) cationexchange. In addition to determining the concentrations of major cations and bromide, the geochemical models indicated the effects of reactions and mixtures on the $\mathrm{pH}$ and the concentrations of minor elements including strontium, barium, potassium, and lithium.

Parallel sets of reaction models initially simulated the addition of road-deicing salt or brine to groundwater, without or with calcite dissolution, but did not consider cation-exchange (fig. 21). The simplest models indicated the effect of increasing additions of road-deicing salt (fig. 21A) or brine (fig. $21 C$ ) to the initial groundwater. For both scenarios, the $\mathrm{pH}$ decreased progressively from the initial value of 5.8, whereas the concentrations of sodium, chloride, and bromide increased. Because the samples that had elevated sodium (53 to $610 \mathrm{mg} / \mathrm{L}$ ) had alkaline $\mathrm{pH}$ (fig. 13A), these conservative mixing models were considered unsatisfactory and were enhanced by specifying that calcite would dissolve to equilibrium (figs. $21 B$ and $D$ ). The resultant models that involved mixing and calcite dissolution produced results that could explain the formation of acidic to near-neutral waters of calcium-sodium/bicarbonate-chloride types, such as samples from wells LY731 or LY719, but not the sodium/bicarbonate types with $\mathrm{pH}$ values greater than 8 .

The geochemical models were modified further to evaluate the potential effects of calcite dissolution plus cationexchange on the $\mathrm{pH}$ and solute concentrations (fig. 22). For these models, instead of road-deicing salt, calcite is added progressively to the initial groundwater, without or with cationexchange (figs. $22 A$ and $B$ ). Likewise, the groundwater plus brine mixing scenarios are considered with cation-exchange, without or with calcite dissolution (figs. $22 C$ and $D$ ). Generally, calcite dissolution alone could produce near-neutral calcium/bicarbonate waters, which were the most common types. Furthermore, a mixture of 0.01 percent to 0.07 percent brine plus groundwater could produce the observed concentrations of bromide and chloride plus other major and trace ions. However, calcite dissolution plus cation-exchange was required to produce the elevated $\mathrm{pH}, \mathrm{ALK}$, and sodium concentrations. The exchange sites were modeled as containing mostly sodium, with minor calcium, magnesium, strontium, barium, and lithium (instead of all sodium). Thus, observed concentrations of strontium, barium, and lithium could be maintained or increased through the exchange reactions.

\section{Isotopic Composition of Methane and Origin of Methane Gas}

Only the five samples (from wells LY700, LY735, LY781, LY785, and LY722) with the highest concentrations of methane ( 0.9 to $16.8 \mathrm{mg} / \mathrm{L}$ ) were analyzed for the stable isotopic compositions of methane, deuterium and carbon, and the associated concentrations of higher-chain hydrocarbon gases (fig. 23). Ethane was detected at concentrations ranging from 0.67 to $60 \mu \mathrm{g} / \mathrm{L}$ in all five samples, propane was detected at concentrations ranging from 0.2 to $0.5 \mu \mathrm{g} / \mathrm{L}$ in four samples, and butane was detected at $0.2 \mu \mathrm{g} / \mathrm{L}$ in one sample. The elevated ratios of methane to ethane plus higher-chain hydrocarbons for all five samples implies a microbial origin of the methane (fig. 23B), owing to the lack of significant microbial generation of the higher-chain hydrocarbon gases (Strąpoć and others, 2011). However, the isotopic compositions of methane in four of the five groundwater samples are consistent with a predominantly thermogenic source of the methane (figs. $23 \mathrm{~A}$ 
$\boldsymbol{A}$

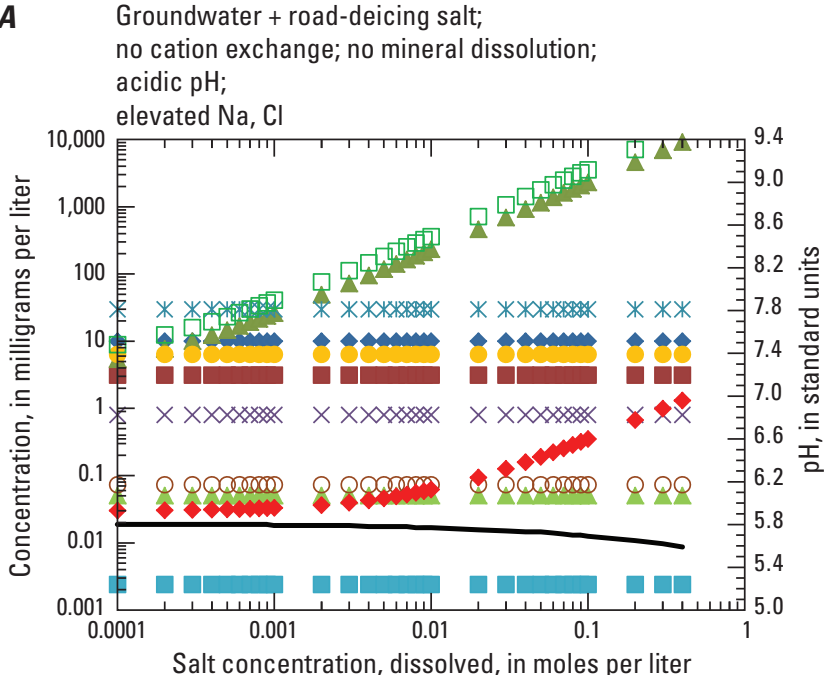

$B$

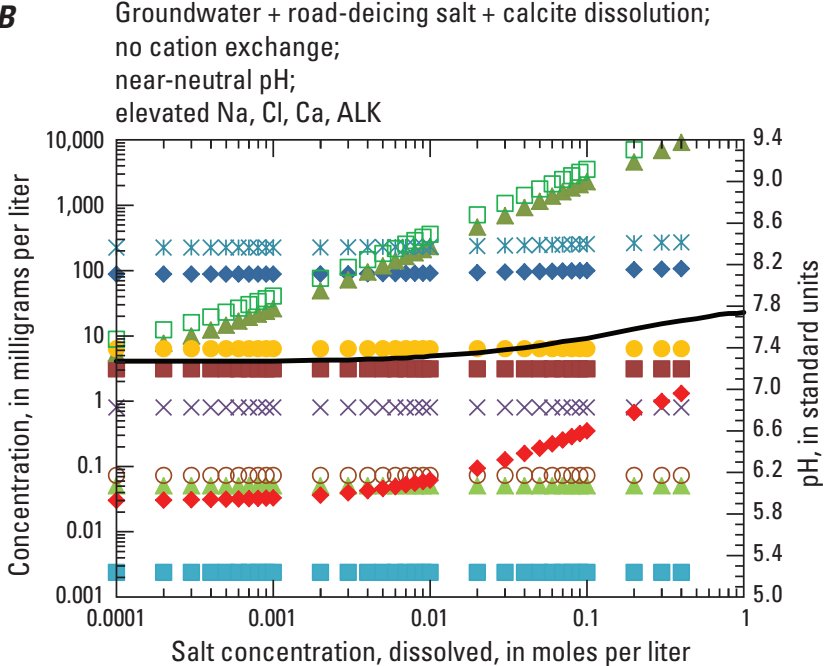

C Groundwater + brine mixture; no cation exchange; no mineral dissolution; acidic $\mathrm{pH}$; low $\mathrm{SO}_{4^{\prime}}$ ALK; elevated $\mathrm{Cl}, \mathrm{Br}, \mathrm{Na}, \mathrm{K}, \mathrm{Li}, \mathrm{Sr}, \mathrm{Ba}, \mathrm{Ca}, \mathrm{Mg}$

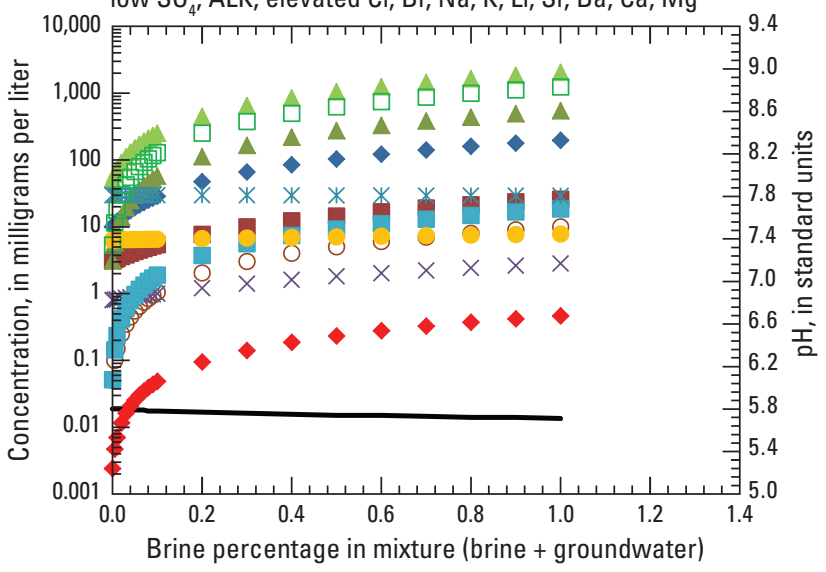

D Groundwater + brine mixture + calcite dissolution; near-neutral $\mathrm{pH}$; low $\mathrm{SO}_{4}$; elevated $\mathrm{Cl}, \mathrm{Br}, \mathrm{Na}, \mathrm{K}, \mathrm{Li}, \mathrm{Sr}, \mathrm{Ca}, \mathrm{Mg}, \mathrm{ALK}$

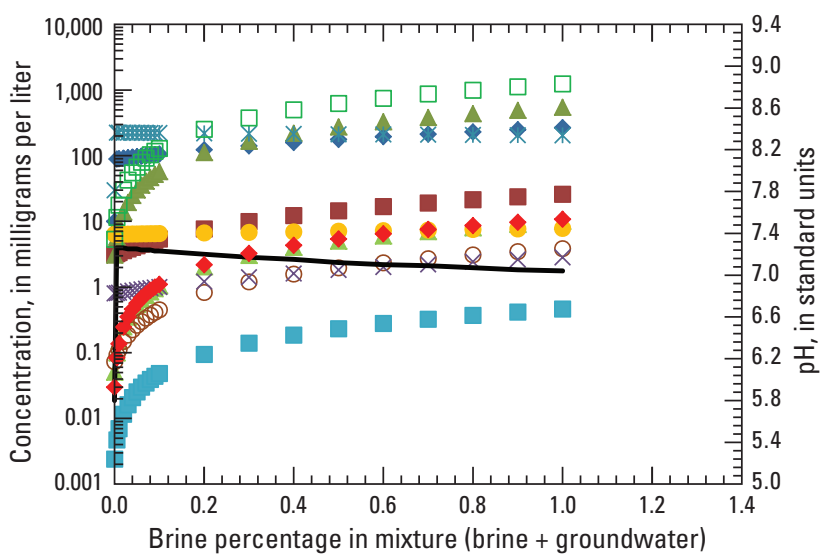

EXPLANATION

$\begin{array}{clcl}- & \mathrm{pH} & \times & \text { Potassium (K) } \\ \bullet & \text { Calcium (Ca) } & \square & \text { Lithium (Li) } \\ \square & \text { Magnesium (Mg) } & * & \text { Alkalinity (ALK) } \\ \triangle & \text { Strontium (Sr) } & \bullet & \text { Sulfate }\left(\mathrm{SO}_{4}\right) \\ \bigcirc \quad & \text { Barium (Ba) } & \square & \text { Chloride (Cl) } \\ \triangle & \text { Sodium (Na) } & \bullet & \text { Bromide (Br) }\end{array}$

Figure 21. Computed compositions of waters resulting from dissolution of road-deicing salt and (or) calcite, but without cationexchange. Low-ionic strength groundwater (LY557) $A$, dissolves road-deicing salt without other reactions; $B$, dissolves road-deicing salt plus dissolves calcite to equilibrium (saturation index $=0$ ); $C$, mixes with median oil and gas well brine (Dresel and Rose, 2010) without reactions; and $D$, mixes with median oil and gas well brine with calcite dissolution to equilibrium. Computations conducted using the aqueous geochemical computer program, PHREEQC (Parkhurst and Appelo, 2013). 
$\boldsymbol{A}$

Groundwater + calcite dissolution;

no cation exchange;

near-neutral $\mathrm{pH}$;

elevated $\mathrm{Ca}, \mathrm{ALK}$



$\boldsymbol{B}$

Groundwater + calcite dissolution + cation exchange; alkaline $\mathrm{pH}$;

low $\mathrm{Cl}, \mathrm{Br}, \mathrm{SO}_{4^{\prime}} \mathrm{Ca}, \mathrm{Mg}$; elevated $\mathrm{ALK}, \mathrm{Na}, \mathrm{K}, \mathrm{Li}, \mathrm{Sr}, \mathrm{Ba}$



C Groundwater + brine mixture + cation exchange; no mineral dissolution; acidic $\mathrm{pH}$;

low $\mathrm{SO}_{4}, \mathrm{Ca}, \mathrm{Mg}$; elevated $\mathrm{ALK}, \mathrm{Cl}, \mathrm{Br}, \mathrm{Na}, \mathrm{K}, \mathrm{Li}$

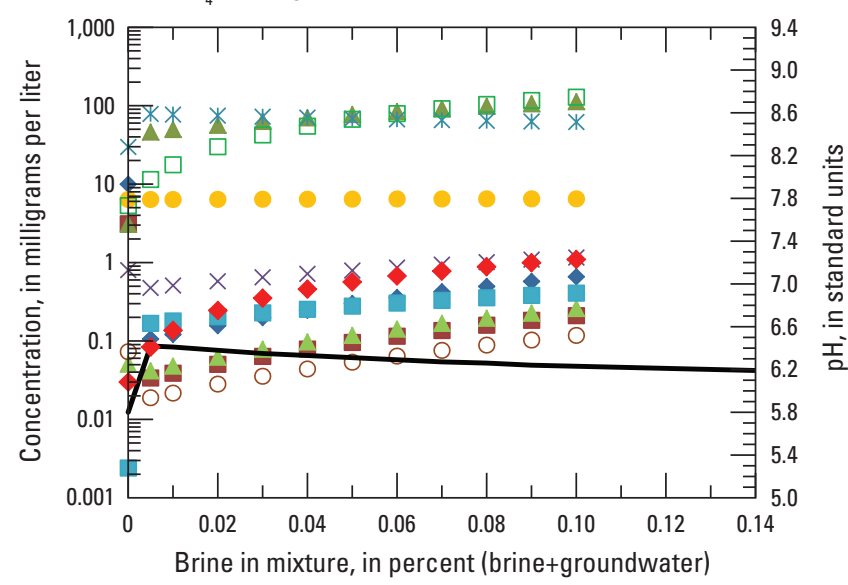

D

Groundwater + brine mixture + calcite dissolution + cation exchange;

alkaline $\mathrm{pH}$;

low $\mathrm{SO}_{4}, \mathrm{Ca}, \mathrm{Mg}$; elevated $\mathrm{ALK}, \mathrm{Cl}, \mathrm{Br}, \mathrm{Na}, \mathrm{K}, \mathrm{Li}, \mathrm{Sr}, \mathrm{Ba}$

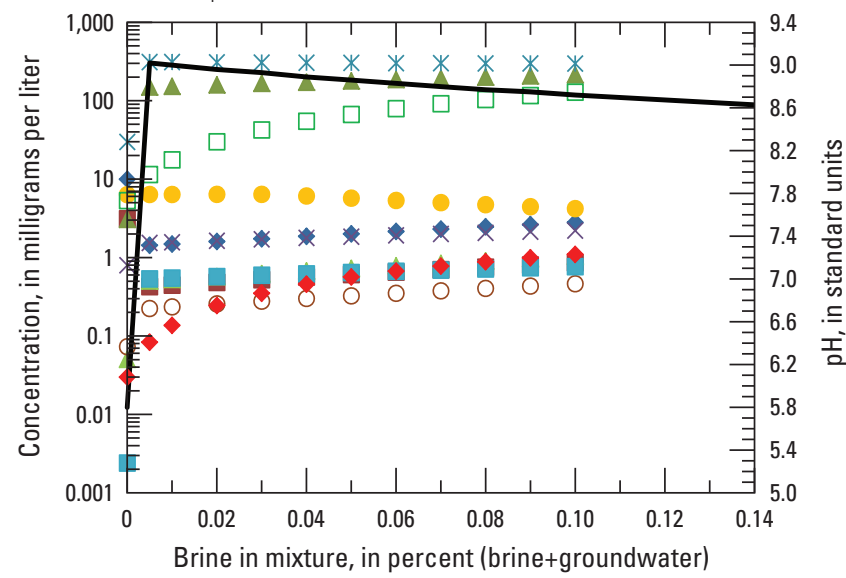

EXPLANATION

$\begin{array}{llll}-\mathrm{pH} & \times & \text { Potassium (K) } \\ \bullet & \text { Calcium (Ca) } & \square & \text { Lithium (Li) } \\ \square & \text { Magnesium (Mg) } & * & \text { Alkalinity (ALK) } \\ \triangle & \text { Strontium (Sr) } & \bullet & \text { Sulfate }\left(\mathrm{SO}_{4}\right) \\ \bigcirc & \text { Barium (Ba) } & \square & \text { Chloride }(\mathrm{Cl}) \\ \triangle & \text { Sodium (Na) } & \bullet & \text { Bromide }(\mathrm{Br})\end{array}$

Figure 22. Computed composition of waters resulting from mixing of different solutions and (or) reactions including dissolution of calcite and cation-exchange. Low-ionic strength groundwater (LY557) dissolves incremental amounts of calcite until reaching equilibrium $A$, without cation-exchange; or $B$, with cation-exchange. Mixing of low-ionic strength groundwater with median oil and gas well brine (Dresel and Rose, 2010) $C$, with cation-exchange; and $D$, with calcite dissolution to equilibrium and cation-exchange. Computations conducted using the aqueous geochemical computer program, PHREEOC (Parkhurst and Appelo, 2013). 
$\boldsymbol{A}$

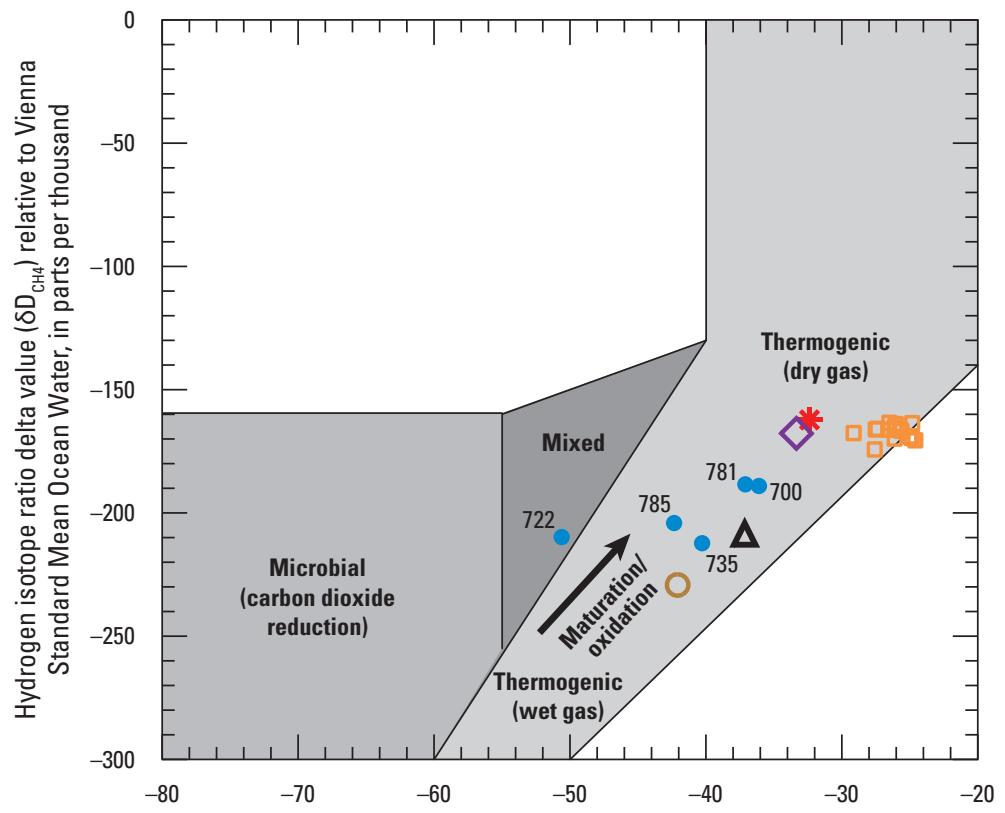

EXPLANATION

Isotopic composition of methane gas in groundwater

- Lycoming County groundwater sample, 2014

Mean isotopic composition of methane gas from mud gas logging of shale-gas wells in Pennsylvania

(Baldassare and others, 2014)

Catskill and Lock Haven Formations

A Brallier Formation

$\checkmark$ Hamilton Group

* Marcellus Formation

Isotopic composition of methane gas, Lycoming County (Reese and others, 2014)

ㅁ Marcellus Formation

Carbon isotope ratio delta value $\left(\delta^{13} \mathrm{C}_{\mathrm{CH} 4}\right)$ relative to Vienna Pee Dee Belemnite, in parts per thousand

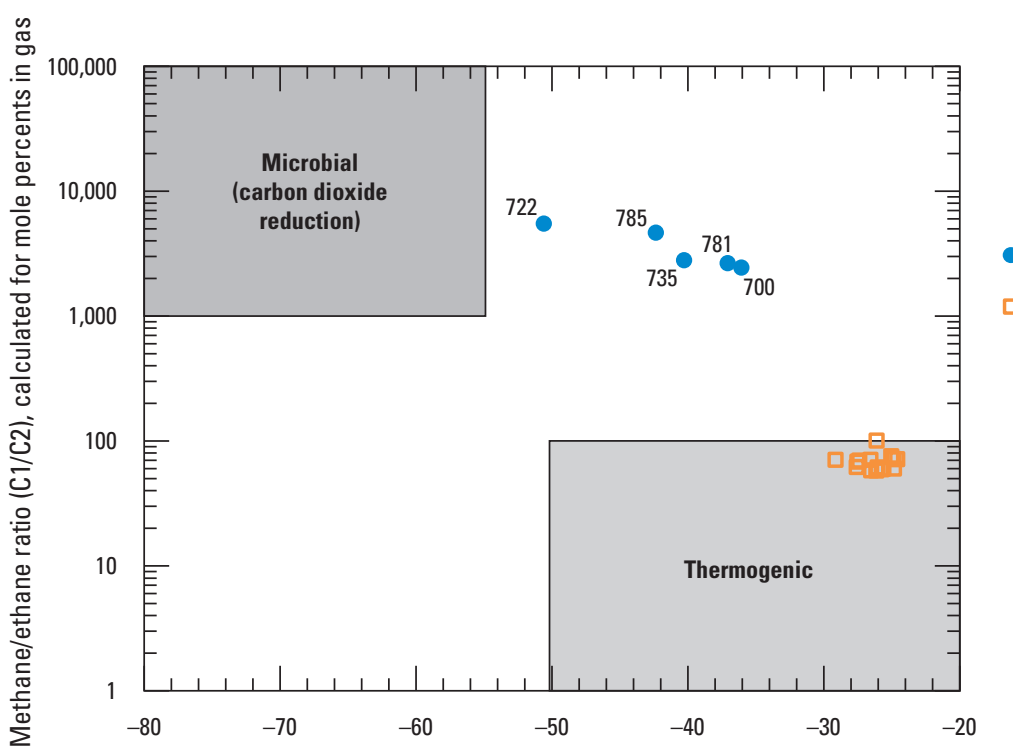

\section{EXPLANATION}

Isotopic composition of carbon in methane gas and methane/ethane ratio (C1/C2)

- Lycoming County groundwater sample, 2014

口 Marcellus Formation methane gas, Lycoming County (Reese and others, 2014)

Carbon isotope ratio delta value $\left(\delta^{13} \mathrm{C}_{\mathrm{CH} 4}\right)$ relative to Vienna Pee Dee Belemnite, in parts per thousand

Figure 23. A, Isotopic composition of methane in groundwater samples collected from five wells in Lycoming County, Pennsylvania, 2014 , and $B$, ratio of methane to higher-chain hydrocarbons in relation to carbon isotopic composition for methane in these samples. Boundaries for microbial and thermogenic gas types and compositional shift related to gas maturation/oxidation, shown by arrow, from Reese and others (2014, figure 30, p. 38). Marcellus Formation methane gas data for Lycoming County from Reese and others (2014, table 7), and mud-gas logging data by geologic formation from Baldassare and others (2014, table 1). 
and 23B). These four samples, from the Catskill and Lock Haven Formations and the Hamilton Group, have carbon isotopic ratios delta values ranging from -42.36 to $-36.08 \%$ and hydrogen isotopic ratios delta values ranging from -212.0 to $-188.4 \%$, which are consistent with the isotopic compositions reported for mud-gas logging samples from these geologic units and a thermogenic source of the methane. The fifth sample had the highest concentration of methane, $16.8 \mathrm{mg} / \mathrm{L}$, with a carbon isotopic ratio delta values of $-50.59 \%$ and a hydrogen isotopic ratio delta values of $-209.7 \%$, which are consistent with methane of mixed thermogenic and microbial origins or, possibly, microbial gas that subsequently underwent oxidation.

The methane in four of these five groundwater samples, from wells located in the Catskill and Lock Haven Formations (LY700, LY735, LY781) and wells located in the Hamilton Group (LY785), have carbon isotopic ratio delta values ranging from -42.36 to $-36.08 \%$ and hydrogen isotopic ratio delta values ranging from -212.0 to $-188.4 \%$, which are consistent with the isotopic compositions reported by Baldassare and others (2014) for mud-gas logging samples from these geologic units; however, the methane in these groundwater samples has lower (lighter) carbon isotopic ratio delta values than those reported by Reese and others (2014) for Marcellus Formation methane gas samples from Lycoming County. The fifth sample (from well LY722) had the highest concentration of methane, $16.8 \mathrm{mg} / \mathrm{L}$, with a carbon isotopic ratio delta values of $-50.59 \%$ and hydrogen isotopic ratio delta values of $-209.7 \%$, which was closer than other samples identifying with a microbial origin of the methane. These characteristics could indicate a mixed thermogenic and microbial source (carbon-dioxide reduction process) of methane and also could imply that methane of microbial origin has been oxidized (becoming isotopically heavier).

Groundwater with relatively elevated methane concentrations (near or above $1 \mathrm{mg} / \mathrm{L}$ ) also had a chemical composition that differed in some respects $(\mathrm{pH}$, selected major ions and inorganic trace constituents) from groundwater with low methane concentrations. The five well-water samples with the highest methane concentrations also had among the highest $\mathrm{pH}$ values (8.25 to 9.0) and elevated concentrations of sodium, lithium, boron, fluoride, arsenic, and bromide. Relatively elevated concentrations of some other constituents, such as barium, strontium, and chloride, commonly were present in, but not limited to, those well-water samples with elevated methane.

\section{Spatial Distribution of Dissolved Methane and Associated Constituents}

The spatial distribution of methane and associated groundwater-quality characteristics in Lycoming County is complex. Generally, the $\mathrm{pH}, \mathrm{SC}$, and associated concentrations of major and trace constituents are related to the predominant bedrock lithology (fig. 3 and table 1), which influences the topography and hydrogeology (Taylor and others, 1984). Boxplots in the appendix (figs. 3-1 through 3-4) illustrate variations in dissolved methane and other constituents as a function of the $\mathrm{pH}, \mathrm{SC}$, redox, and lithology. Additionally, spatial relations of the water quality are illustrated by boxplots of the land surface elevation, well depth, well bottom elevation, and water temperature by major lithology, $\mathrm{pH}$, and $\mathrm{SC}$ (fig. 24).

In general, the uplands in northern areas of Lycoming County, which are underlain predominantly by sandstone bedrock usually have dilute (low conductivity), slightly acidic, oxygenated, calcium-bicarbonate type waters. In contrast, areas of intermediate altitudes in southern areas of the county, which are underlain by shale and siltstone bedrock, usually have calcium-bicarbonate and sodium bi-carbonate groundwater with near-neutral to alkaline $\mathrm{pH}$ values and moderate to high conductivity. A subset of samples from the shale and siltstone lithologies is characterized as sodium-chloride type water, which generally had the highest $\mathrm{pH}$ values along with elevated arsenic, sodium, lithium, and bromide concentrations. Areas of low to intermediate altitudes in the southern areas where carbonate bedrock predominates generally have groundwater with near neutral $\mathrm{pH}$ and highest amounts of hardness (calcium and magnesium).

Llewellyn (2014) described possible associations between elevated methane or brine signatures with deep faulting and associated structural features; however, the available data for this study indicate that no one physical factor such as the topographic setting, well depth, or altitude at the bottom of the well was particularly useful for predicting those well locations with an elevated dissolved concentration of methane. The five samples that had methane concentrations near or greater than $1 \mathrm{mg} / \mathrm{L}$ were from four of the six topographic settings, including valleys, lower slopes, upper slopes, and gentle slopes (fig. 25). Elevated methane was not associated with the waters from ridge settings; no wells were sampled, if present, in the steep slope topographic setting. The wells from which the elevated-methane samples had been collected had depths ranging from 149 to 500 feet. The two samples with the highest methane concentrations (fig. 25) were collected from wells with depths of 300 and 400 feet and with bottom elevations of 404 and 385 feet above the NAVD 88, respectively, in order of increasing methane concentration. Furthermore, as previously discussed, the sample with the greatest methane concentration (LY722) and two other samples with elevated methane (LY700 and LY785) had chloride/bromide ratios and corresponding chloride/sodium ratios that were indicative of a sodium chloride source and not a brine source (fig. 20). Methane in sample LY722 had an isotopic composition that could result by the oxidation of a microbial source (fig. 23). In contrast, three of the other four samples analyzed for isotopic composition (LY735, LY760, and LY781) had sodium, chloride, and bromide characteristics that were consistent with mixing of a fresh groundwater with a deep brine source. 

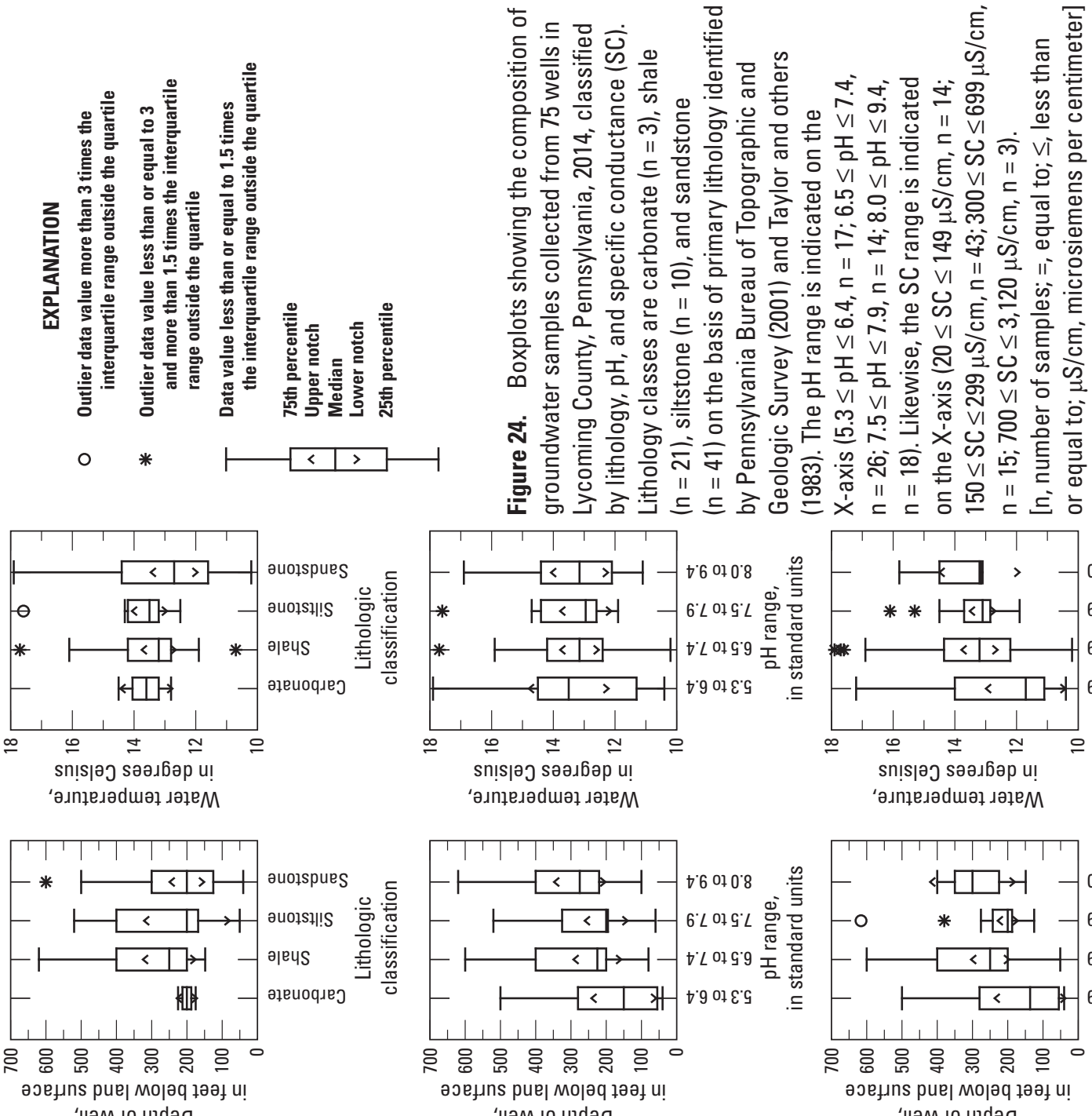

‘|ә '॥әм Һо पұdә0
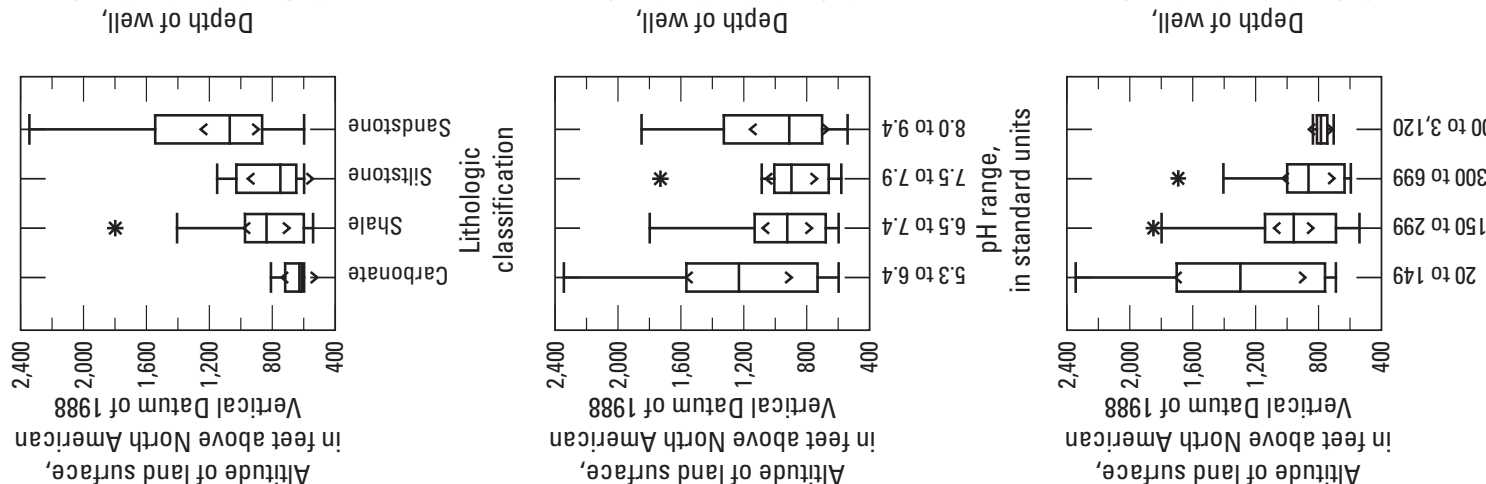



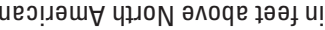

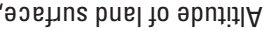
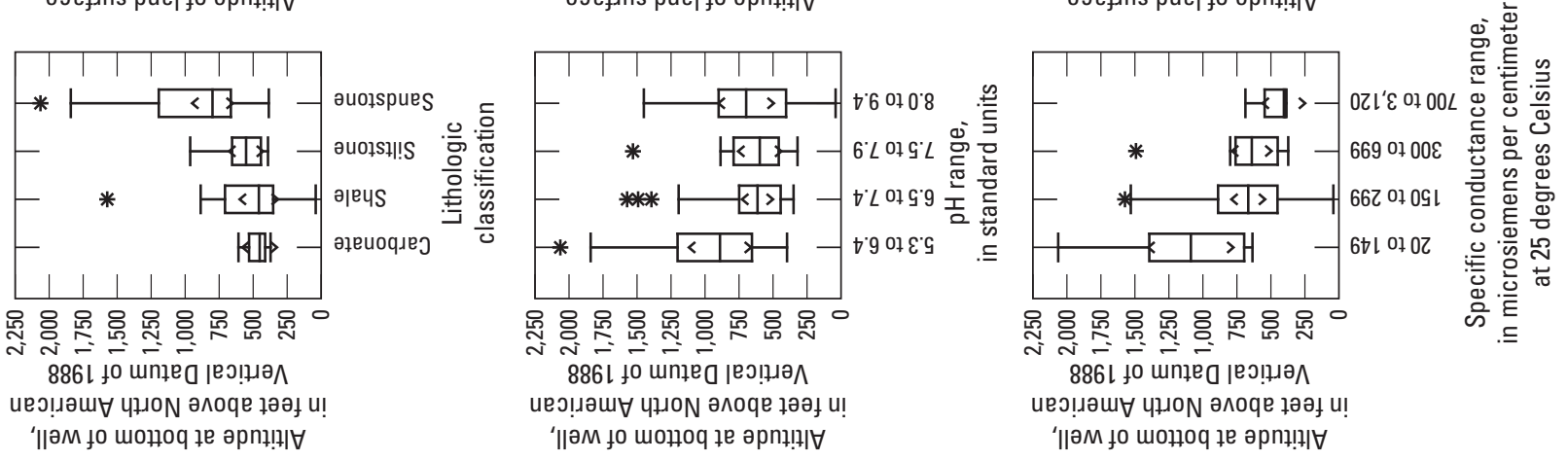


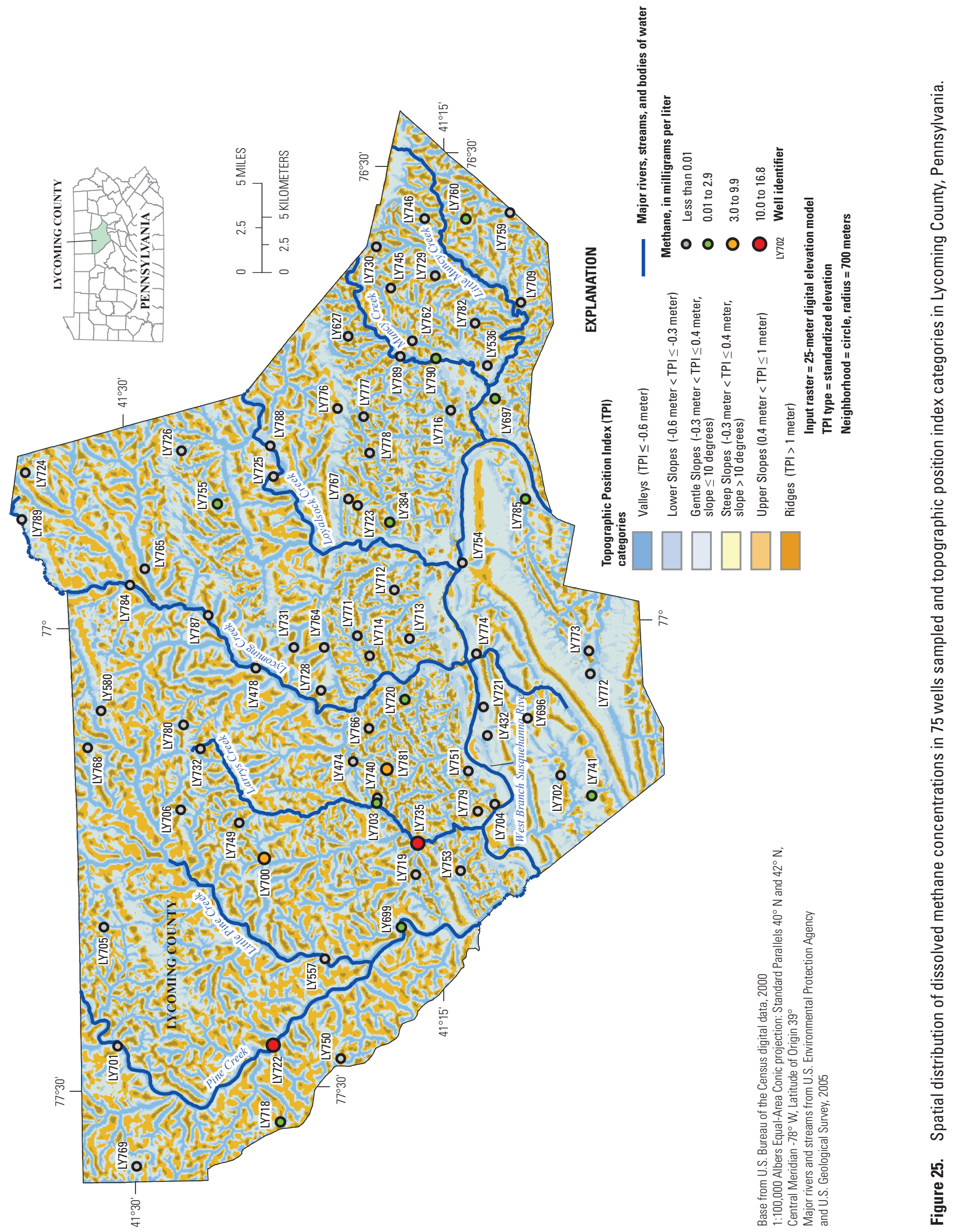




\section{Summary and Conclusions}

Approximately 43 percent of the population of Lycoming County, Pennsylvania, has a self-supplied drinking-water source, primarily groundwater. The groundwater used for water supply is mostly derived from wells completed in fractured bedrock (primarily sandstone, siltstone, shale, or limestone) and may also be derived from wells in alluvium and glacial outwash and drift overlying the bedrock in the stream valleys in the northern one-half of the county. This report, prepared in cooperation with Lycoming County, presents analytical data for groundwater samples from 75 domestic wells sampled throughout Lycoming County in June, July, and August 2014. The samples were collected using existing pumps and plumbing prior to any treatment and analyzed for physical and chemical properties, major ions, nutrients, radionuclides, metals and trace elements, manmade organic compounds, and dissolved gases, including methane and radon-222. Results for specific constituents are evaluated in relation to drinking-water standards established by the U.S. Environmental Protection Agency (EPA), which include maximum contaminant levels (MCLs), secondary maximum contaminant levels (SMCLs), and health advisory levels (HALs). These data are also used to indicate the variations among different bedrock lithologies (natural characteristics) and possible effects from human activities on the groundwater resource.

The groundwater quality generally met most drinkingwater standards, but some samples exceeded MCLs, SMCLs, or HALs for arsenic, iron, manganese, total dissolved solids (TDS), chloride, $\mathrm{pH}$, bacteria, or radon-222. Arsenic concentrations were higher than the MCL of 10 micrograms per liter $(\mu \mathrm{g} / \mathrm{L})$ in 9 of the 75 (12 percent) well-water samples, with concentrations as high as $23.6 \mu \mathrm{g} / \mathrm{L}$; arsenic concentrations were higher than the HAL of $2 \mu \mathrm{g} / \mathrm{L}$ in 23 samples (31 percent). Total iron concentrations exceeded the SMCL of $300 \mu \mathrm{g} / \mathrm{L}$ in 20 of the 75 samples; total manganese exceeded the SMCL of $50 \mu \mathrm{g} / \mathrm{L}$ in 20 of the 75 samples and the HAL of $300 \mu \mathrm{g} / \mathrm{L}$ in 2 of those 20 samples. Two samples had chloride concentrations that exceeded the SMCL of 250 milligrams per liter $(\mathrm{mg} / \mathrm{L})$, and both of those samples exceeded the SMCL of $500 \mathrm{mg} / \mathrm{L}$ for TDS. The $\mathrm{pH}$ of water samples ranged from 5.3 to 9.15 and did not meet the SMCL range of 6.5 to 8.5 in 22 samples, with 17 samples having a $\mathrm{pH}$ less than 6.5, and 8 samples having $\mathrm{pH}$ greater than 8.5 . Generally, samples that had elevated TDS, chloride, or arsenic concentrations had high $\mathrm{pH}$. Total coliform bacteria were detected in 39 of 75 samples (52 percent), with Escherichia coli detected in 10 of those 39 samples. Radon-222 activities ranged from non-detect to 7,420 picocuries per liter ( $\mathrm{pCi} / \mathrm{L}$ ), with a median of $863 \mathrm{pCi} / \mathrm{L}$, and exceeded the proposed drinking-water standard of 300 $\mathrm{pCi} / \mathrm{L}$ in 50 of the 75 samples (67 percent); radon-222 activities were higher than the alternative proposed standard of $4,000 \mathrm{pCi} / \mathrm{L}$ in 3 of the 75 samples.

Water from 15 of 75 (20 percent) wells had concentrations of methane greater than the reporting level of 0.01 milligrams per liter $(\mathrm{mg} / \mathrm{L})$, which ranged from 0.04 to
$16.8 \mathrm{mg} / \mathrm{L}$. Two samples had methane concentrations (13.1 and $16.8 \mathrm{mg} / \mathrm{L}$ ) exceeding the action level of $7 \mathrm{mg} / \mathrm{L}$. Low levels of ethane (up to $0.12 \mathrm{mg} / \mathrm{L}$ ) were present in five samples with the highest methane concentrations. The occurrence of hydrocarbon gas composed of predominantly methane with minor concentrations of higher chain hydrocarbons (ethane, propane, and butane) could indicate a microbial source of the methane. Nevertheless, methane in four of these groundwater samples, from the Catskill and Lock Haven Formations and the Hamilton Group, had carbon isotopic ratio delta values ranging from -42.36 to -36.08 parts per thousand (\%o) and hydrogen isotopic ratio delta values ranging from -212.0 to $-188.4 \%$, which are consistent with the isotopic compositions reported for mud-gas logging samples from these geologic units and a thermogenic source of the methane. The fifth sample had the highest concentration of methane, $16.8 \mathrm{mg} / \mathrm{L}$, with a carbon isotopic ratio delta values of $-50.59 \%$ and a hydrogen isotopic ratio delta values of $-209.7 \%$ o that are consistent with methane of mixed thermogenic and microbial gas that subsequently underwent oxidation.

Groundwater with relatively elevated methane concentrations (near or above $1 \mathrm{mg} / \mathrm{L}$ ) also had a chemical composition that differed in some respects $(\mathrm{pH}$, selected major ions and inorganic trace constituents) from groundwater with low methane concentrations. The five well-water samples with the highest methane concentrations also had among the highest $\mathrm{pH}$ values (8.25 to 9.0) and elevated concentrations of sodium, lithium, boron, fluoride, arsenic, and bromide. Relatively elevated concentrations of some other constituents, such as barium, strontium, and chloride, commonly were present in, but not limited to, those well-water samples with elevated methane and $\mathrm{pH}$.

Three of the six groundwater samples with the highest methane concentrations had chloride/bromide ratios that are consistent with mixing fresh groundwater with a small amount of brine ( 0.02 percent or less) similar in composition to those reported for gas and oil well brines in Pennsylvania. Such brines generally may be naturally present at undetermined depths below the freshwater aquifer. The sample with the highest methane concentration and most other samples with low methane concentrations (less than about $1 \mathrm{mg} / \mathrm{L}$ ) have chloride/bromide ratios that indicate predominantly anthropogenic sources of chloride, such as road-deicing salt, septic systems, and (or) animal waste. Although brines may be naturally present and originate from deeper parts of the aquifer system, the anthropogenic sources are more likely to affect shallow groundwater.

The spatial distribution of groundwater compositions generally is related to the predominant bedrock. In general, (1) uplands underlain by sandstone bedrock in the northern area of Lycoming County usually have relatively dilute, slightly acidic, oxygenated, calcium-bicarbonate type waters; (2) the southern area of low to intermediate altitudes underlain by carbonate bedrock usually has calcium-bicarbonate water with moderate to high conductivity, near-neutral $\mathrm{pH}$, and highest amounts of hardness (calcium and magnesium); and (3) the 
southern area underlain by shale and siltstone bedrock usually has water with near-neutral to alkaline $\mathrm{pH}$ values $\geq 8$ and highest arsenic, sodium, lithium, and bromide concentrations. Geochemical modeling indicated that for samples with elevated $\mathrm{pH}$, sodium, lithium, bromide, and alkalinity, the water chemistry could have resulted by dissolution of calcite (calcium carbonate) combined with cation-exchange and mixing with a small amount of brine. Through cation-exchange reactions, which are equivalent to processes in a water softener, calcium ions released by calcite dissolution are exchanged for sodium ions on clay minerals. Consequently, the water becomes undersaturated with calcite and can dissolve additional calcite; through repeated exchange and dissolution steps, the $\mathrm{pH}$ can increase to values greater than 8 . Constituents such as arsenic tend to be mobile at high $\mathrm{pH}$. Thus, the current assessment of groundwater quality in Lycoming County generally meets drinking-water standards established by the EPA, but concentrations of arsenic may exceed MCLs and HALs. Some samples in various parts of the aquifer indicated groundwaters that can have elevated concentrations of iron and manganese and low to moderate concentrations of methane and some constituents that are typically found in high concentrations in natural brine and produced waters from gas and oil wells.

\section{References Cited}

Appelo, C.A.J., and Postma, Dieke, 2005, Geochemistry, groundwater and pollution ( $2 \mathrm{~d}$ ed.): Leiden, The Netherlands, A.A. Balkema Publishers, 649 p.

Back, William, 1966, Hydrochemical facies and ground-water flow patterns in northern part of Atlantic Coastal Plain: U.S. Geological Survey Professional Paper 498-A, p. A1-A42; 1 pl. in pocket, accessed June 16, 2016, at https://pubs.er.usgs. gov/publication/pp498A.

Baldassare, F.J., McCaffrey, M.A., and Harper, J.A., 2014, A geochemical context for stray gas investigations in the northern Appalachian Basin: Implications of analyses of natural gases from Neogene through Devonian-age strata: American Association of Petroleum Geologists Bulletin v. 98, no. 2, p. 341-372, DOI:10.1306/06111312178, accessed June 16, 2016, at http://archives.datapages.com/data/ bulletns/2014/02feb/BLTN12178/BLTN12178.HTM?q=\%2 BauthorStrip \%3Abaldassare.

Ball, J.W., and Nordstrom, D.K., 1991, User's manual for WATEQ4F, with revised thermodynamic data base and test cases for calculating speciation of major, trace, and redox elements in natural waters: U.S. Geological Survey OpenFile Report 91-183, 189 p, accessed June 16, 2016 at https:// pubs.er.usgs.gov/publication/ofr91183.
Barbash, J.E., and Resek, E.A., 1996, Pesticides in ground water-Distribution, trends, and governing factors: Chelsea, Mich., Ann Arbor Press, 598 p.

Belitz, Kenneth, Jurgens, Bryant, Landon, M.K., Fram, M.S., and Johnson, Tyler, 2010, Estimation of aquifer scale proportion using equal area grids: Assessment of regional scale groundwater quality: Water Resources Research, v. 46, no. 11, [variously paged], W11550, DOI: 10.1029/2010WR009321, accessed June 16, 2016, at http:// onlinelibrary.wiley.com/doi/10.1029/2010WR009321/full.

Bethke, C.M., and Yeakel, S., 2010, The Geochemist's Workbench Release 8.0: GWB essentials guide: Champaign, Illinois, Aqueous Solutions, LLC, 116 p.

Carter, J.M., Delzer, G.C., Kingsbury, J.K., and Hopple, J.A., 2007, Concentration data for anthropogenic organic compounds in ground water, surface water, and finished water of selected community water systems in the United States, 2002-05: U.S. Geological Survey Data Series 268, 30 p., accessed June 16, 2016, at http://pubs.usgs.gov/ ds/2007/268/.

Chapman, E.C., Capo, R.C., Stewart, B.W., Kirby, C.S., Hammack, R.W., Schroeder, K.T., and Edenborn, H.M., 2012, Geochemical and strontium isotope characterization of produced waters from Marcellus Shale natural gas extraction: Environmental Science \& Technology, v. 46, p., no. 6, 3,545-3,553, DOI: 10.1021/es204005g, accessed June 16, 2016, at http://pubs.acs.org/doi/abs/10.1021/es204005g.

Commonwealth of Pennsylvania, 2014, The Pennsylvania code chapter 78: Oil and gas wells, accessed March 31, 2014, at http://www.pacode.com/secure/data/025/chapter78/ chap78toc.html.

Davis, S.N., Whittemore, D.O., and Fabryka-Martin, June, 1998, Uses of chloride/bromide ratios in studies of potable water: Groundwater, v. 36, no. 2, p. 338-350, DOI: 10.1111/j.1745-6584.1998.tb01099.x, accessed June 16, 2016, at http://onlinelibrary.wiley.com/ doi/10.1111/j.1745-6584.1998.tb01099.x/abstract.

Denver, J.M., Cravotta, C.A., III, Ator, S.W., and Lindsey, B.D., 2010, Contributions of phosphorus from groundwater to streams in the Piedmont, Blue Ridge, and Valley and Ridge Physiographic Provinces, Eastern United States: U.S. Geological Survey Scientific Investigations Report 20105176, 38 p., accessed June 16, 2016, at http://pubs.usgs.gov/ $\operatorname{sir} / 2010 / 5176 /$.

Dresel, P.E., and Rose, A.W., 2010, Chemistry and origin of oil and gas well brines in western Pennsylvania: Pennsylvania Geological Survey, 4th ser., Open-File Report OFOG 10-01.0, 48 p., accessed June 16, 2016, at http://dcnr.state. pa.us/topogeo/publications/pgspub/openfile/index.htm. 
Drever, J.I., 1997, The geochemistry of natural waters-surface and groundwater environments ( $3 \mathrm{~d}$ ed.): Upper Saddle River, New Jersey, Prentice Hall, 436 p.

Dufor, C.N., and Becker, Edith, 1964, Public water supplies of the 100 largest cities in the United States, 1962: U.S. Geological Survey Water-Supply Paper 1812, 364 p, accessed June 16, 2016, at https://pubs.er.usgs.gov/publication/wsp1812.

Duro, Lara, Grivé, Mireia, and Giffaut Eric, 2012, ThermoChimie, the ANDRA thermodynamic database: MRS Proceedings, v. 1475, accessed June 16, 2016, at http://dx.doi. org/10.1557/opl.2012.637.

Dzombak, D.A., and Morel, F.M.M., 1990, Surface complexation modeling: hydrous ferric oxide: New York, WileyInterscience, $393 \mathrm{p}$.

Federal Register, 1999, National primary drinking water regulations; radon-222: Federal Register, v. 64, no. 211, p. 59245-59294.

Feth, J.H.F., 1965, Preliminary map of the conterminous United States showing depth to and quality of shallowest ground water containing more than 1,000 parts per million dissolved solids: U.S. Geological Survey Hydrologic Atlas 199, 31 p., 2 pls, accessed June 16, 2016, at https://pubs. er.usgs.gov/publication/ha199.

Fishman, M.J., and Friedman, L.C., eds., 1989, Methods for determination of inorganic substances in water and fluvial sediments: U.S. Geological Survey Techniques of Water-Resources Investigations, book 5, chap. A1, 545 p., accessed June 16, 2016, at https://pubs.usgs.gov/twri/twri5a1/pdf/TWRI_5-A1.pdf.

Halusczak, L.O., Rose, A.W., and Kump, L.R., 2013, Geochemical evaluation of flowback brine from Marcellus gas wells in Pennsylvania, USA: Applied Geochemistry, v. 28 , p. 55-61, accessed June 16, 2016, at http://dx.doi. org/10.1016/j.apgeochem.2012.10.002.

Hanor, J. S., 1968, Frequency distribution of compositions in the barite-celestite series: American Mineralogist, v. 53, p. 1215-1222.

Hanshaw, B.B., and Back, William, 1979, Major geochemical processes in the evolution of carbonate-aquifer systems: Journal of Hydrology, v. 43, p. 287-312.

Hayes, T., 2009, Sampling and analysis of water streams associated with the development of Marcellus Shale gas, Report by Gas Technology Institute, Des Plaines, Ill., for the Marcellus Shale Coalition. <http://www.bucknell.edu/script/ environmentalcenter/marcellus/default.aspx?articleid=14 >
Heisig, P.M., and Scott, Tia-Marie, 2013, Occurrence of methane in groundwater of south-central New York State, 2012 - Systematic evaluation of a glaciated region by hydrogeologic setting: U.S. Geological Survey Scientific Investigations Report 2013-5190, 32 p., accessed June 16, 2016, at http://dx.doi.org/10.3133/sir20135190.

Helsel, D.R. and Hirsch, R.M., 2002, Statistical methods in water resources: U.S. Geological Survey Techniques of Water-Resources Investigations, book 4, chap. A3, 522 p., accessed June 16, 2016, at https://pubs.usgs.gov/twri/ twri4a3/.

Hem, J.D., 1985, Study and interpretation of the chemical characteristics of natural water (3d ed.): U.S. Geological Survey Water-Supply Paper 2254, 264 p, accessed June 16, 2016, at http://pubs.usgs.gov/wsp/wsp2254/.

Joreskog, K.G., Klovan, J.E., and Reyment, R.A., 1976, Geological factor analysis: New York, Elsevier, 178 p.

Kargbo, D.M., Wilhelm, R.G., and Campbell, D.J., 2010, Natural gas plays in the Marcellus Shale - Challenges and potential opportunities: Environmental Science \& Technology, v. 44, no. 15, p. 5,679-5,684, DOI: 10.1021/ es903811p, accessed June 16, 2016, at http://pubs.acs.org/ doi/abs/10.1021/es903811p.

Kerr, R.A., 2010, Natural gas from shale bursts onto the scene: Science, v. 328, p. 1624-1626, accessed June 16, 2016, at http://science.sciencemag.org/content/328/5986/1624.

Llewellyn, G.T., 2014, Evidence and mechanisms for Appalachian Basin brine migration into shallow aquifers in NE Pennsylvania, USA: Hydrogeology Journal, v. 22, no. 5, p. 1,055-1,066, DOI: 10.1007/s10040-014-1125-1, accessed June 16, 2016, at http://link.springer.com/article/10.1007/ s10040-014-1125-1?view=classic.

Lloyd, O.B., Jr., and Carswell, L.D., 1981, Groundwater resources of the Williamsport region, Lycoming County, Pennsylvania: Pennsylvania Geological Survey, 4th ser., Water Resource Report 51, 69 p.

Lycoming County Planning Commission, 2001, Lycoming County Pennsylvania Water Supply Plan: prepared by Science Applications International Corporation, Harrisburg, Pa., accessed October 29, 2015, at http://www.lyco.org/ portals/1/planningcommunitydevelopment/documents/ edps_pdfs/wsp_final_report.pdf.

McCleskey, R.B., Nordstrom, D.K., Ryan, J.N., and Ball, J.W., 2012, A new method of calculating electrical conductivity with applications to natural waters: Geochimica et Cosmochimica Acta, v. 77, p. 369-382, accessed June 16, 2016, at http://dx.doi.org/10.1016/j.gca.2011.10.031. 
McMahon, P.B., and Chapelle, F.H., 2008, Redox processes and water quality of selected principal aquifer systems: Groundwater, v. 46, no. 2, p. 259-271, DOI: 10.1111/j.1745-6584.2007.00385.x, accessed June 16, 2016, at http://onlinelibrary.wiley.com/doi/10.1111/j.17456584.2007.00385.x/abstract.

Mullaney, J.R., Lorenz, D.L., and Arntson, A.D., 2009. Chloride in groundwater and surface water in areas underlain by the glacial aquifer system, northern United States: U.S. Geological Survey Scientific Investigations Report, 20095086, 41 p., accessed June 16, 2016, at http://pubs.usgs.gov/ $\operatorname{sir} / 2009 / 5086 /$.

Nordstrom, D.K., and Munoz, J.L., 1986, Geochemical thermodynamics: Palo Alto, Blackwell Scientific Publications, $477 \mathrm{p}$.

Ohio Environmental Protection Agency, 2012, Tier I Data Validation Manual: Ohio Environmental Protection Agency, Division of Environmental Response and Revitalization, 138 p., accessed September 12, 2016, at http://truestory.hol. es/read/validation-of-u-s-environmental-protection-agency. pdf.

Parkhurst, D.L., and Appelo, C.A.J., 2013, Description of input and examples for PHREEQC version 3-A computer program for speciation, batch-reaction, one-dimensional transport, and inverse geochemical calculations: U.S. Geological Survey Techniques and Methods 6-A43, 497 p., accessed June 16, 2016, at https://pubs.usgs.gov/tm/06/a43/ pdf/tm6-A43.pdf.

Pennsylvania Bureau of Topographic and Geologic Survey, 1998, Preliminary landform subdivisions of Pennsylvania, 1998: Pennsylvania Bureau of Topographic and Geologic Survey, Department of Conservation and Natural Resources, digital data, accessed June 23, 2008, at http://www.pasda. psu.edu.

Pennsylvania Bureau of Topographic and Geologic Survey, 2001, Bedrock geology of Pennsylvania: Pennsylvania Bureau of Topographic and Geologic Survey, Department of Conservation and Natural Resources, digital data, accessed January 9, 2014 at http://www.dcnr.state.pa.us/topogeo/ map1/bedmap.aspx.

Pennsylvania Bureau of Topographic and Geologic Survey, 2014, Pennsylvania groundwater information system (PaGWIS) documentation: Pennsylvania Bureau of Topographic and Geologic Survey, 4th ser., SQL database, accessed January 9, 2014 from http://www.denr.state.pa.us/topogeo/ groundwater/pagwis/index.htm.

Pennsylvania Department of Conservation and Natural Resources, 2013a, DCNR - State forest lands 2013: Pennsylvania Department of Conservation and Natural Resources, vector digital data, accessed January 29, 2014, at http://www.pasda.psu.edu.
Pennsylvania Department of Conservation and Natural Resources, 2013b, DCNR state parks 201308: Pennsylvania Department of Conservation and Natural Resources, Bureau of State Parks, vector digital data, accessed January 29, 2014, at http://www.pasda.psu.edu.

Pennsylvania Department of Environmental Protection, 2012, PA-DEP Recommended Basic Oil \& Gas Pre-Drill Parameters, Factsheet 8000-FS-DEP4300 Rev. 11/2012.

Pennsylvania Department of Environmental Protection, 2013, Public water supplier's (PWS) service areas: Pennsylvania Department of Environmental Protection, digital data, accessed December 6, 2013, at http://www.pasda.psu.edu

Pennsylvania Department of Environmental Protection, 2016, Oil \& gas locations - conventional unconventional: Pennsylvania Department of Environmental Protection, vector digital data, accessed June 9, 2016, at http://www.pasda.psu. edu/.

Pennsylvania Department of Transportation, 2013, PennDOT - Pennsylvania Stateroads: Pennsylvania Department of Transportation, Bureau of Planning and Research, Geographic Information Division, digital dataset, accessed January 13, 2014, at http://www.pasda.psu.edu.

Pennsylvania Game Commission, 2013, PGC State Game Lands 2013: Pennsylvania Game Commission, vector digital data, accessed January 29, 2014, at http://www.pasda. psu.edu.

Peters, N.E., and Bonelli, J.E., 1982, Chemical composition of bulk precipitation in the north-central and northeastern United States, December 1980 through February 1981: U.S. Geological Survey Circular 874, 63 p.

Poth, C.W., 1962, The occurrence of brine in western Pennsylvania: Pennsylvania Geological Survey, 4th ser., Mineral Resources Report 47, 53 p.

PRISM Group at Oregon State University, 2006a, United States average monthly or annual maximum temperature, 1971-2000: PRISM Group at Oregon State University, digital data, accessed May 19, 2009, at http://www.prism.oregonstate.edu/products/matrix. phtml? vartype $=$ tmax $\&$ view $=$ data .

PRISM Group at Oregon State University, 2006b, United States average monthly or annual minimum temperature, 1971-2000: PRISM Group at Oregon State University, digital data, accessed May 19, 2009, at http://www.prism.oregonstate.edu/products/matrix. phtml? vartype $=$ tmin\&view $=$ data .

PRISM Group at Oregon State University, 2006c, United States average monthly or annual precipitation, 1971-2000: PRISM Group at Oregon State University, digital data, accessed May 19, 2009, at http://www.prism.oregonstate. edu/products/matrix.phtml?vartype=ppt\&view $=$ data . 
P-STAT, Inc., 2008, P-STAT Version 2.23 Release 11, May, 2008. Hopewell, New Jersey, USA.

Reese, S.O., Neboga, V.V., Pelepko, Seth, Kosmer, W.J., and Beattie, Stewart, 2014, Groundwater and petroleum resources of Sullivan County, Pennsylvania: Pennsylvania Geological Survey, 4th ser., Water Resource Report 71, 99 p., 6 pls., 27 p., appendix.

Reilly, Darren, Singer, David, Jefferson, Anne, and Eckstein, Yoram, 2015, Identification of local groundwater pollution in northeastern Pennsylvania: Marcellus flowback or not?: Environmental Earth Sciences, vol. 73, no. 12, p. 8,097-8,109, DOI: $10.1007 / \mathrm{s} 12665-014-3968-0$, accessed June 20, 2016, at http://link.springer.com/article/10.1007\% 2Fs12665-014-3968-0.

SAS Institute, Inc., 2012, SAS 9.4 for Windows: Cary, NC, USA.

Scott, J.C., 1990, Computerized stratified random site-selection approaches for design of a ground-water-quality sampling network: U.S. Geological Survey-Water Resources Investigations Report 90-4101, 109 p., accessed June 20, 2016, at https://pubs.er.usgs.gov/publication/wri904101.

Senior, L.A., 2014, A reconnaissance spatial and temporal assessment of methane and inorganic constituents in groundwater in bedrock aquifers, Pike County, Pennsylvania, 2012-13: U.S. Geological Survey Scientific Investigations Report 2014-5117, 91 p.

Senior, L.A., Cravotta, C.A., III, and Sloto, R.A., 2016, Baseline assessment of groundwater quality in Wayne County, Pennsylvania, 2014: U.S. Geological Survey Scientific Investigations Report 2016-5073, 136 p., DOI: 10.3133/ sir20165073, accessed July 16, 2016, at http://pubs.usgs. gov/sir/2016/5073/sir20165073.pdf.

Siegel, D.I., Smith, B., Perry, E., Bothun, R., and Hollingsworth, M., 2015, Pre-drilling water-quality data of groundwater prior to shale gas drilling in the Appalachian Basin: Analysis of the Chesapeake Energy Corporation dataset: Applied Geochemistry, v. 63, p. 37-57, accessed June 20, 2016, at http://dx.doi.org/10.1016/j.apgeochem.2015.06.013.

Sloto, R.A., 2013, Baseline groundwater quality from 20 domestic wells in Sullivan County, Pennsylvania, 2012: U.S. Geological Survey Scientific Investigations Report 2013-5085, 27 p., accessed June 20, 2016, at http://pubs. usgs.gov/sir/2013/5085/.

Smedley, P.L., and Kinniburgh, D.G., 2002, A review of the source, behaviour and distribution of arsenic in natural waters: Applied Geochemistry, v. 17, no. 5, p. 517-568, accessed June 20, 2016, at http://dx.doi.org/10.1016/S08832927(02)00018-5.
Snoeyink, V.L., and Jenkins, D., 1981, Water chemistry: New York, John Wiley \& Sons., 463 p.

Strąpoć, D., Mastalerz, M., Dawson, K., Macalady, J., Callaghan, A.V., Wawrik, B., Turich, C., and Ashby, M., 2011, Biogeochemistry of microbial coal-bed methane: Annual Review of Earth and Planetary Sciences, vol. 39, p. 617656, accessed April 26, 2016, at http://dx.doi.org/10.1146/ annurev-earth-040610-133343.

Taylor, L.E., Werkheiser, W.H., and Kriz, M.L., 1983, Groundwater resources of the West Branch Susquehanna River Basin, Pennsylvania: Pennsylvania Geological Survey, 4th ser., Water Resources Report 56, 143 p.

Thyne, Geoffrey, Güler, Cüneyt, and Poeter, Eileen, 2004, Sequential analysis of hydrochemical data for watershed characterization: Groundwater, v. 42 , no. 5 , p. 711-723, DOI: 10.1111/j.1745-6584.2004.tb02725.x, accessed June 20, 2016, at http://onlinelibrary.wiley.com/ doi/10.1111/j.1745-6584.2004.tb02725.x/abstract.

U.S. Bureau of the Census, 2000, 2000 County \& county equivalent areas: U.S. Bureau of the Census, digital data, accessed June 11, 2008, at http://www.census.gov/geo/ www/cob/co2000.html.

U.S. Bureau of the Census, 2010, U.S. Census TIGER/Line ${ }^{\circledR}$ Shapefile, 2010, 2010 State, Pennsylvania, 2010 Census Block state-based: U.S. Department of Commerce, U.S. Census Bureau, Geography Division, digital data, accessed February 7, 2013, at http://www.census.gov/geo/www/tiger.

U.S. Bureau of the Census, 2011, Census 2000 \& 2010 Redistricting data (Public Law 94-171) summary file: prepared by The Pennsylvania State Data Center, Middletown, Pa., accessed October 29, 2015, at http://pasdc.hbg.psu.edu/ sdc/pasdc_files/census2010/032011_release/MCD_PA_ PL-2010-2000_Total-Population.xls.

U.S. Environmental Protection Agency, 2001, Total coliform rule-A quick reference guide: Washington, D.C., U.S. Environmental Protection Agency, Office of Water, EPA 816-F-01-035, 2 p., accessed June 22, 2016, at https://nepis. epa.gov/Exe/ZyPDF.cgi?Dockey=3000663W.txt.

U.S. Environmental Protection Agency, 2003, Drinking water advisory: consumer acceptability advice and health effects analysis on sodium: Washington, D.C., U.S. Environmental Protection Agency Office of Water, EPA 822-R-03-006, 29 p. accessed June 22, 2016, at https://www.epa.gov/sites/ production/files/2014-09/documents/support_cc1_sodium_ dwreport.pdf.

U.S. Environmental Protection Agency, 2012, 2012 Edition of the drinking water standards and health advisories: U.S. Environmental Protection Agency EPA 822-S-12-001, accessed February 12, 2014, at http://water.epa.gov/action/ advisories/drinking/upload/dwstandards2012.pdf. 
U.S. Environmental Protection Agency, 2014, Natural gas extraction-hydraulic fracturing: U.S. Environmental Protection Agency, accessed February 12, 2014, at http://water. epa.gov/type/groundwater/uic/class2/hydraulicfracturing/.

U.S. Environmental Protection Agency and U.S. Geological Survey, 2005, National Hydrography Dataset Plus - NHDPlus: U.S. Environmental Protection Agency and U.S. Geological Survey, vector digital data, accessed June 1, 2007, at http://www.horizon-systems.com/NHDPlus/NHDPlusV1_02.php.

U.S. Geological Survey, 2002, Marcellus Shale assessment unit - national assessment of oil and gas project - Appalachian basin province (067) assessment units: U.S. Geological Survey, Central Energy Resources Team, vector digital data, accessed February 24, 2005, at http://www.pasda.psu. edu.

U.S. Geological Survey, 2009, 1-Arc second National Elevation Dataset: U.S. Geological Survey, SDE raster digital data, accessed September 8, 2009, at https://ta.cr.usgs.gov/ NED.

U.S. Geological Survey, 2014, NLCD 2011 land cover (2011 edition): U.S. Geological Survey, remote-sensing image, accessed April 2, 2014 at http://www.mrlc.gov.

U.S. Geological Survey, 2015, USGS water data for Pennsylvania, accessed February 11, 2015, at http://waterdata.usgs. gov/pa/nwis/nwis.
U.S. Geological Survey, variously dated, National field manual for the collection of water-quality data: U.S. Geological Survey Techniques of Water-Resources Investigations, |book 9, chaps. A1-A10, available online at http://pubs. water.usgs.gov/twri9A.

Velleman, P.F., and Hoaglin, D., 1981, Applications, basics, and computing of exploratory data analysis: Boston, Mass., Duxbury Press, 354 p.

Warner, N.R., Jackson, R.B., Darrah, T.H., Osborn, S.G., Down, Adrian, Zhao, Kaiguang, White, Alissa, and Vengosh, Avner, 2012, Geochemical evidence for possible natural migration of Marcellus Formation brine to shallow aquifers in Pennsylvania: Proceedings of the National Academy of Sciences, v. 109, no. 30, p. 11961-11966, DOI: 10.1073/pnas.1121181109, accessed June 22, 2016, at http:// www.pnas.org/content/109/30/11961.abstract.

Whittemore, D.O., 2007, Fate and identification of oil-brine contamination in different hydrogeologic settings: Applied Geochemistry, v. 22, no. 10, p. 2,099-2,114, accessed June 22, 2016, at http://dx.doi.org/10.1016/j.apgeochem.2007.04.002.

Zogorski, J.S., Carter, J.M., Ivahnenko, Tamara, Lapham, W.W., Moran, M.J., Rowe, B.L., Squillace, P.J., and Toccalino, P.L., 2006, The quality of our Nation's watersVolatile organic compounds in the Nation's ground water and drinking-water supply wells: U.S. Geological Survey Circular 1292, 101 p., accessed June 22, 2016, at http:// pubs.usgs.gov/circ/circ1292/. 


\section{Appendixes 1, 2, and 3}

\section{Appendix 1}

Table: Compilation of data not available in the National Water Information Sytem (doi http://dx.doi.org/10.5066/ F7P55KJN), including station name, station identification number, lithologic class, and topographic position index, for wells sampled by the U.S. Geological Survey in Lycoming County, Pennsylvania, June-August 2014. (Appendix 1 available online as Excel file at https://doi.org/10.3133/sir20165143)

\section{Appendix 2}

Table: Spearman rank correlation coefficient (r) matrix for groundwater chemical data Lycoming County, Pennsylvania, 2014. (Appendix 2 available online as Excel file at https://doi.org/10.3133/sir20165143)

\section{Appendix 3}

Boxplots: Distributions of continuous variables were compared among different sample classifications using notched boxplots (Velleman and Hoaglin, 1981; Helsel and Hirsch, 2002). Statistically significant correlation coefficients and boxplots are presented. Where the median for a group is greater than the common reporting limit, it is displayed as a horizontal line within the box that is defined by the $25^{\text {th }}$ and $75^{\text {th }}$ percentiles for that group; otherwise, the median is displayed at the reporting limit. If the notched intervals around the medians for sample subsets do not overlap, the medians are statistically different at the 95-percent confidence interval. 


\section{Appendix 3. Boxplots}

Distributions of continuous variables were compared among different sample classifications using notched boxplots (Velleman and Hoaglin, 1981; Helsel and Hirsch, 2002). Statistically significant correlation coefficients and boxplots are presented. Where the median for a group is greater than the common reporting limit, it is displayed as a horizontal line within the box that is defined by the $25^{\text {th }}$ and $75^{\text {th }}$ percentiles for that group; otherwise, the median is displayed at the reporting limit. If the notched intervals around the medians for sample subsets do not overlap, the medians are statistically different at the 95-percent confidence interval.

Figure 3-1: pH

Figure 3-2: Specific conductance

Figure 3-3: Redox

Figure 3-4: Lithologic class 

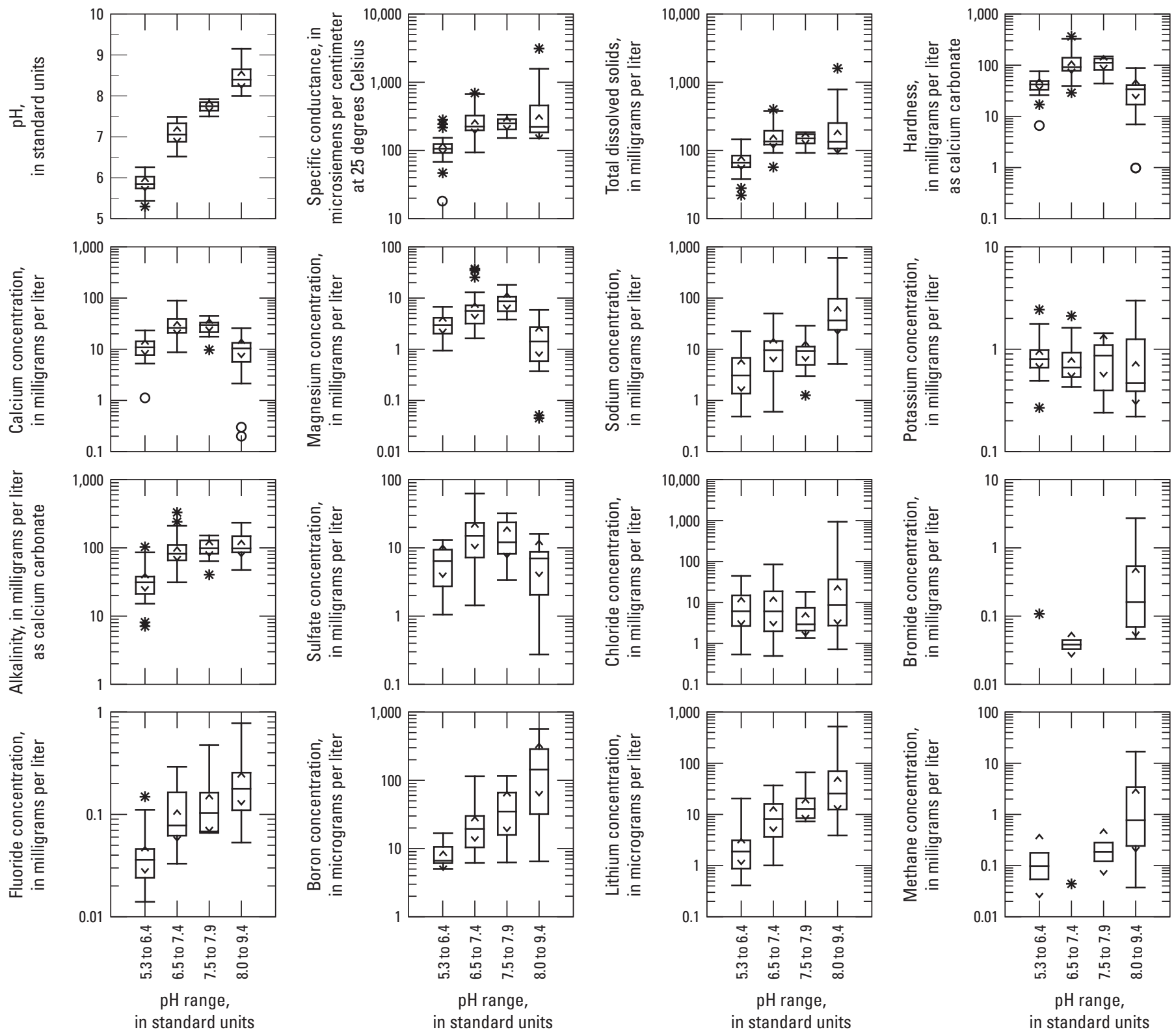

\section{EXPLANATION}

○ Outlier data value more than 3 times the interquartile range outside the quartile

* Outlier data value less than or equal to 3 and more than 1.5 times the interquartile range outside the quartile



in standard units

Figure 3-1. Boxplots showing the composition of 75 groundwater samples from Lycoming County, Pennsylvania, 2014, classified by $\mathrm{pH}$ class interval. The $\mathrm{pH}$ range is indicated on the $\mathrm{X}$-axis $(5.3 \leq \mathrm{pH} \leq 6.4, \mathrm{n}=17 ; 6.5 \leq \mathrm{pH} \leq 7.4, \mathrm{n}=26 ; 7.5 \leq \mathrm{pH} \leq 9.4, \mathrm{n}=32)$. ( $\leq$, greater than or equal to; n, number of samples; $=$, equal to) 

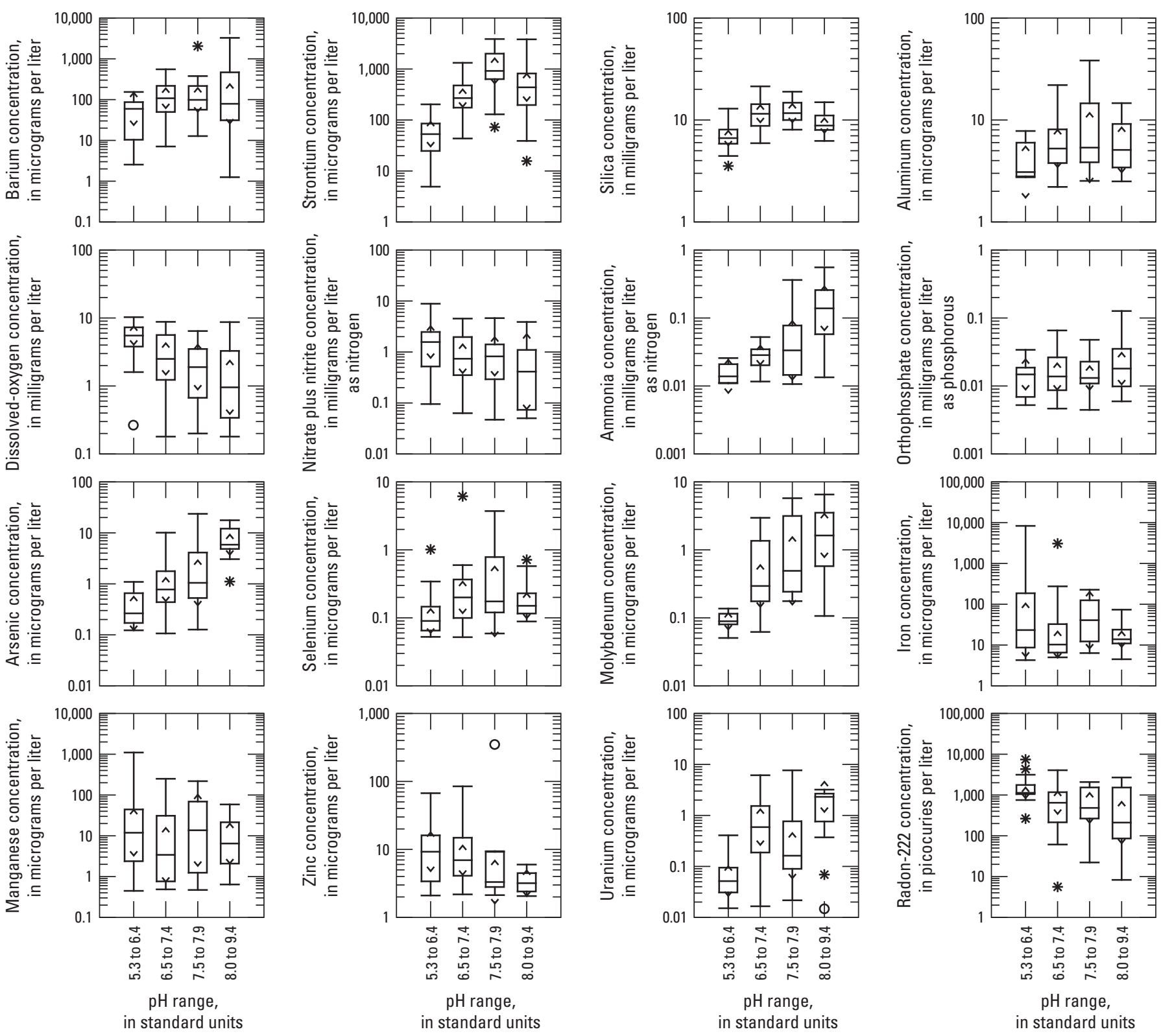

\section{EXPLANATION}

O Outlier data value more than 3 times the interquartile range outside the quartile

* Outlier data value less than or equal to 3 and more than 1.5 times the interquartile range outside the quartile

$\begin{aligned} & \text { Data value less than or equal to } 1.5 \text { times } \\ & \text { the interquartile range outside the quartile }\end{aligned}$
$\begin{aligned} & \text { 75th percentile } \\ & \text { Upper notch } \\ & \text { Median } \\ & \text { Lower notch } \\ & \text { 25th percentile }\end{aligned}$

Figure 3-1. Boxplots showing the composition of 75 groundwater samples from Lycoming County, Pennsylvania, 2014, classified by pH class interval. The $\mathrm{pH}$ range is indicated on the $\mathrm{X}$-axis $(5.3 \leq \mathrm{pH} \leq 6.4, \mathrm{n}=17 ; 6.5 \leq \mathrm{pH} \leq 7.4, \mathrm{n}=26 ; 7.5 \leq \mathrm{pH} \leq 9.4, \mathrm{n}=32)$. ( $\leq$, greater than or equal to; $n$, number of samples; $=$, equal to) —Continued 



pH range,

in standard units

EXPLANATION

○ Outlier data value more than 3 times the interquartile range outside the quartile

* Outlier data value less than or equal to 3 and more than 1.5 times the interquartile range outside the quartile



Figure 3-1. Boxplots showing the composition of 75 groundwater samples from Lycoming County, Pennsylvania, 2014, classified by pH class interval. The $\mathrm{pH}$ range is indicated on the $\mathrm{X}$-axis $(5.3 \leq \mathrm{pH} \leq 6.4, \mathrm{n}=17 ; 6.5 \leq \mathrm{pH} \leq 7.4, \mathrm{n}=26 ; 7.5 \leq \mathrm{pH} \leq 9.4, \mathrm{n}=32)$. ( $\leq, \mathrm{greater}$ than or equal to; $n$, number of samples; =, equal to)—Continued 



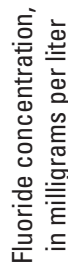

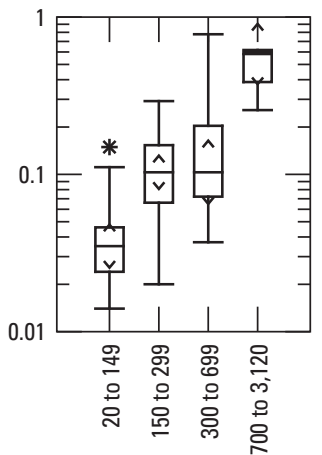

Specific-conductance range, in microsiemens per centimeter at 25 degrees Celsius

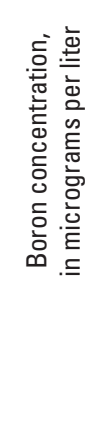

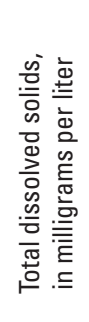
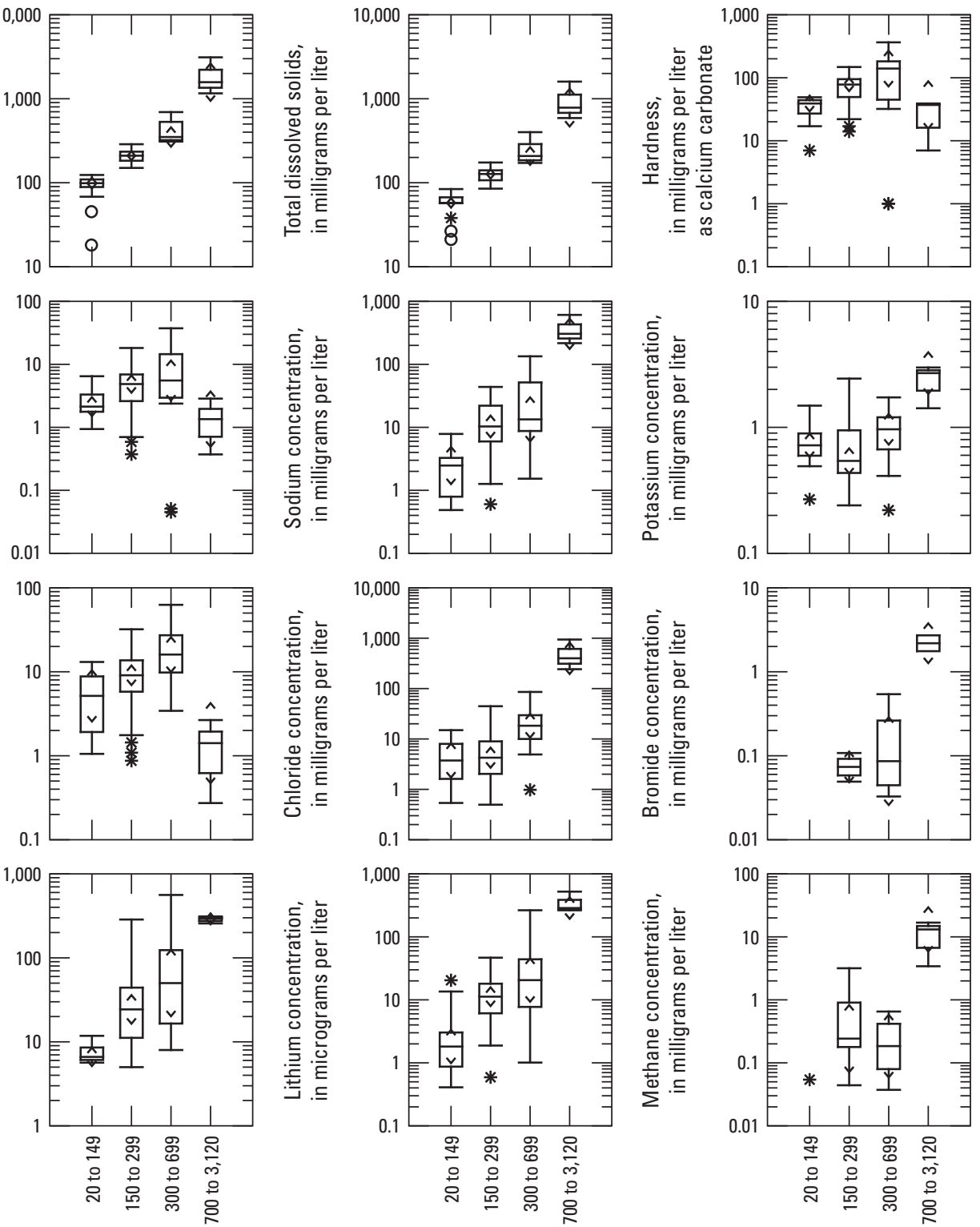

Specific-conductance range, in microsiemens per centimeter at 25 degrees Celsius
Specific-conductance range,
in microsiemens per centimeter at 25 degrees Celsius

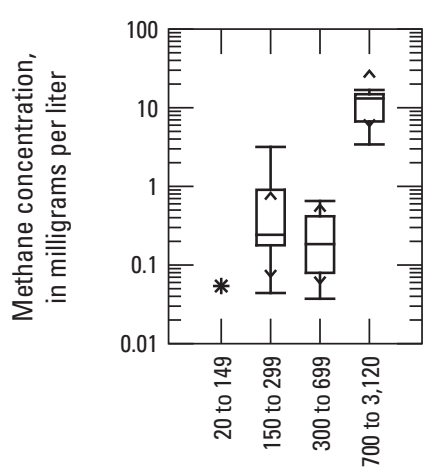

Specific-conductance range, in microsiemens per centimeter at 25 degrees Celsius

\section{EXPLANATION}

O Outlier data value more than $\mathbf{3}$ times the interquartile range outside the quartile

* Outlier data value less than or equal to 3 and more than 1.5 times the interquartile range outside the quartile

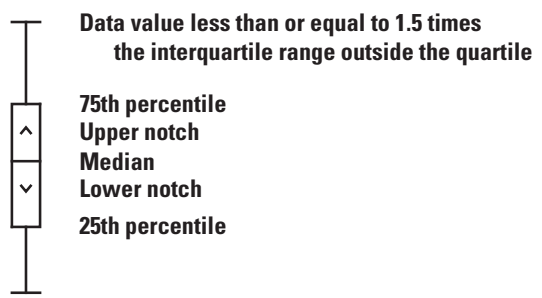

Figure 3-2. Boxplots showing the composition of 75 groundwater samples from Lycoming County, Pennsylvania, 2014, classified by specific conductance (SC) class interval. The SC range is indicated on the X-axis $(20 \leq \mathrm{SC} \leq 149 \mu \mathrm{S} / \mathrm{cm}, \mathrm{n}=14 ; 150 \leq \mathrm{SC} \leq 299 \mu \mathrm{S} / \mathrm{cm}$, $\mathrm{n}=43 ; 300 \leq \mathrm{SC} \leq 699 \mu \mathrm{S} / \mathrm{cm}, \mathrm{n}=15 ; 700 \leq \mathrm{SC} \leq 3,120 \mu \mathrm{S} / \mathrm{cm}, \mathrm{n}=3$ ). Note that nitrate, aluminum, and zinc were not detected for the subset of samples in the highest $S C$ class interval. (SC, specific conductance; $\leq$, greater than or equal to; $\mu \mathrm{S} / \mathrm{cm}$, microsiemens per centimeter; n, number of samples; =, equal to) 

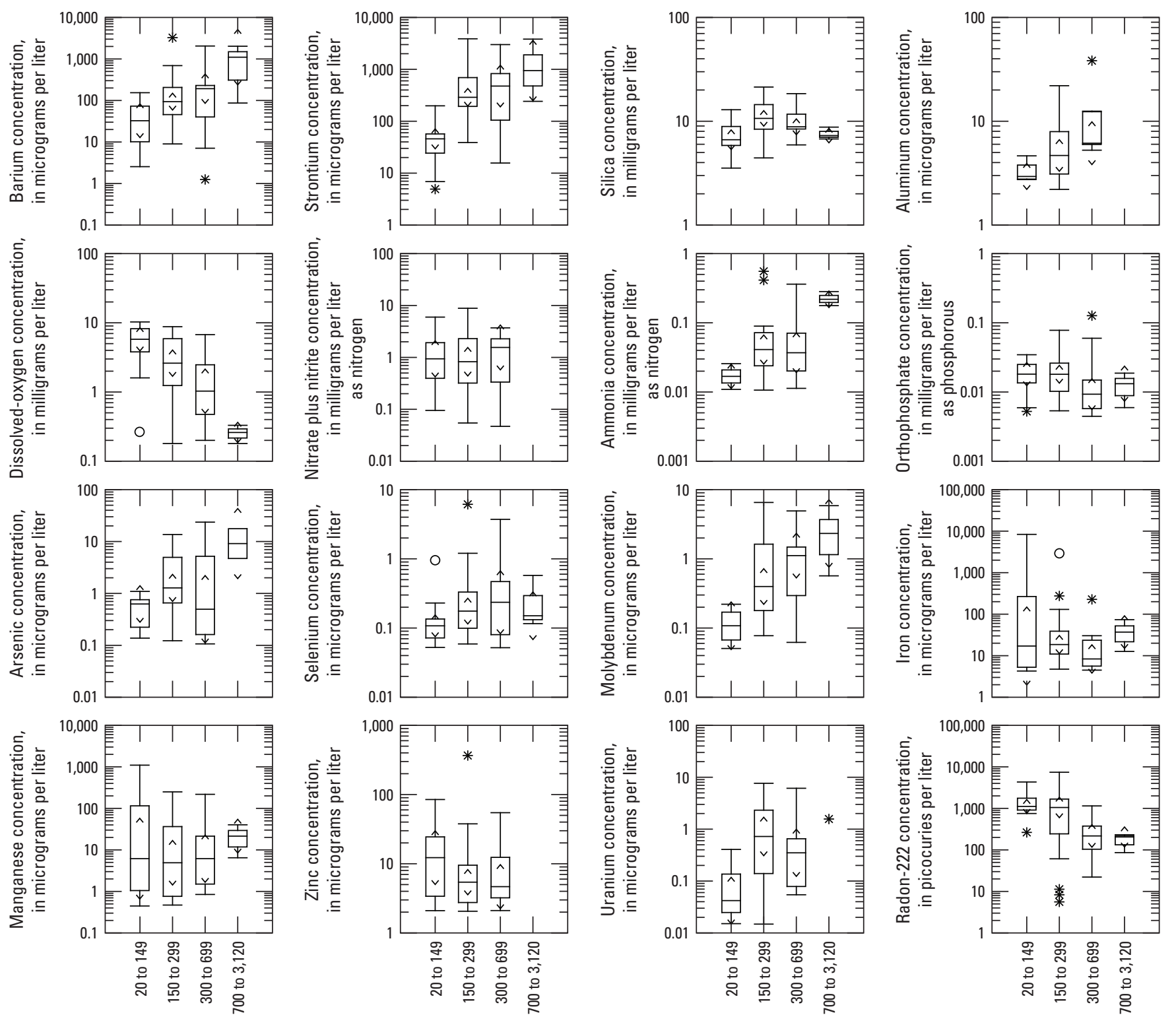

Specific-conductance range, in microsiemens per centimeter at 25 degrees Celsius

\section{Specific-conductance range, in microsiemens per centimeter} at 25 degrees Celsius

\section{Specific-conductance range, in microsiemens per centimeter} at 25 degrees Celsius
Specific-conductance range, in microsiemens per centimeter at 25 degrees Celsius

\section{EXPLANATION}

O Outlier data value more than 3 times the interquartile range outside the quartile

* Outlier data value less than or equal to 3 and more than 1.5 times the interquartile range outside the quartile

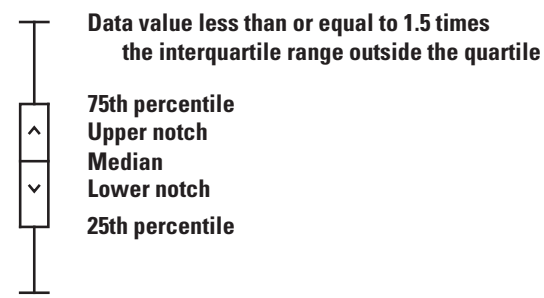

Figure 3-2. Boxplots showing the composition of 75 groundwater samples from Lycoming County, Pennsylvania, 2014, classified by specific conductance (SC) class interval. The SC range is indicated on the X-axis $(20 \leq \mathrm{SC} \leq 149 \mu \mathrm{S} / \mathrm{cm}, \mathrm{n}=14 ; 150 \leq \mathrm{SC} \leq 299 \mu \mathrm{S} / \mathrm{cm}$, $\mathrm{n}=43 ; 300 \leq \mathrm{SC} \leq 699 \mu \mathrm{S} / \mathrm{cm}, \mathrm{n}=15 ; 700 \leq \mathrm{SC} \leq 3,120 \mu \mathrm{S} / \mathrm{cm}, \mathrm{n}=3$ ). Note that nitrate, aluminum, and zinc were not detected for the subset of samples in the highest SC class interval. (SC, specific conductance; $\leq$, greater than or equal to; $\mu \mathrm{S} / \mathrm{cm}$, microsiemens per centimeter; $n$, number of samples; =, equal to)—Continued 


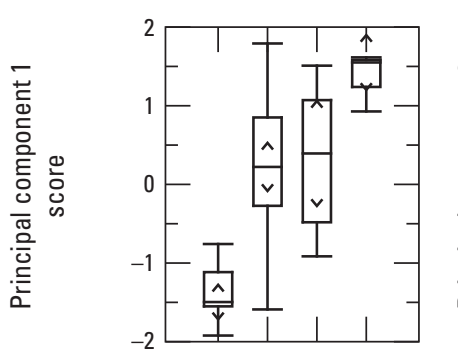

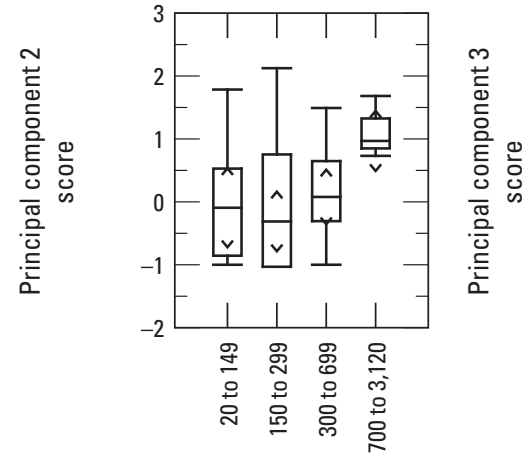

Specific-conductance range, in microsiemens per centimeter at 25 degrees Celsius

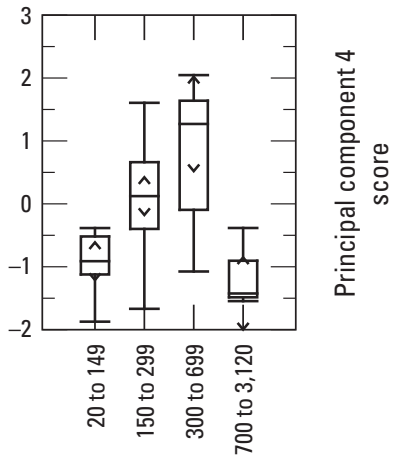

Specific-conductance range, in microsiemens per centimeter at 25 degrees Celsius

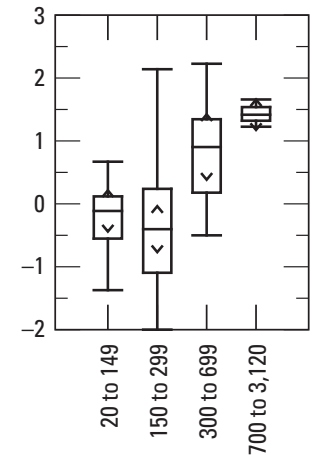

Specific-conductance range, in microsiemens per centimeter at 25 degrees Celsius

\section{EXPLANATION}

- Outlier data value more than 3 times the interquartile range outside the quartile

* Outlier data value less than or equal to 3 and more than 1.5 times the interquartile range outside the quartile

Data value less than or equal to 1.5 times the interquartile range outside the quartile

75th percentile

Upper notch

Median

Lower notch

25th percentile

Figure 3-2. Boxplots showing the composition of 75 groundwater samples from Lycoming County, Pennsylvania, 2014, classified by specific conductance (SC) class interval. The SC range is indicated on the X-axis $(20 \leq \mathrm{SC} \leq 149 \mu \mathrm{S} / \mathrm{cm}, \mathrm{n}=14 ; 150 \leq \mathrm{SC} \leq 299 \mu \mathrm{S} / \mathrm{cm}$, $\mathrm{n}=43 ; 300 \leq \mathrm{SC} \leq 699 \mu \mathrm{S} / \mathrm{cm}, \mathrm{n}=15 ; 700 \leq \mathrm{SC} \leq 3,120 \mu \mathrm{S} / \mathrm{cm}, \mathrm{n}=3$ ). Note that nitrate, aluminum, and zinc were not detected for the subset of samples in the highest $\mathrm{SC}$ class interval. (SC, specific conductance; $\leq$, greater than or equal to; $\mu \mathrm{S} / \mathrm{cm}$, microsiemens per centimeter; $n$, number of samples; $=$, equal to $)$-Continued 

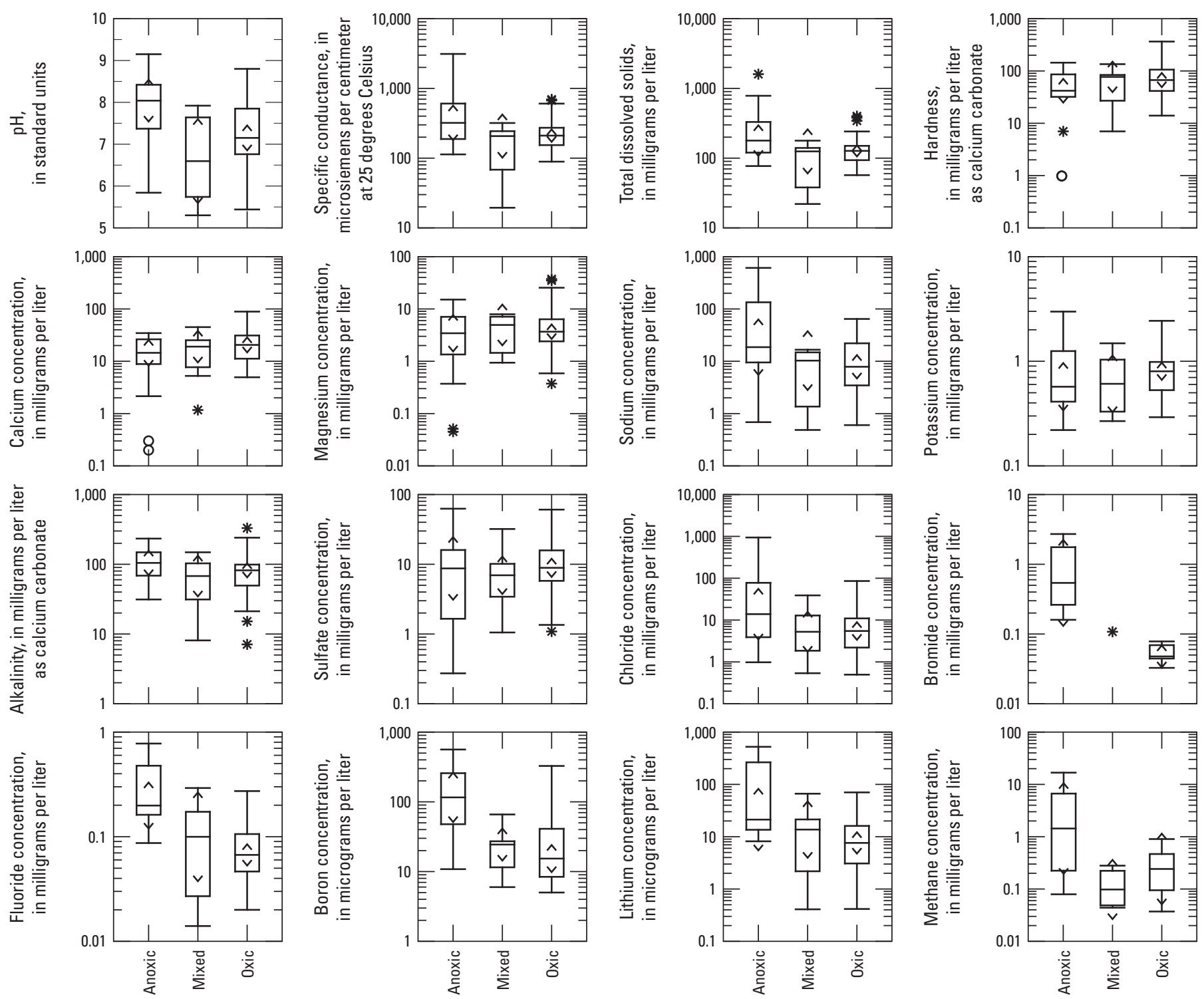

Redox classification

Redox classification

Redox classification

Redox classification

\section{EXPLANATION}

O Outlier data value more than 3 times the interquartile range outside the quartile

* Outlier data value less than or equal to 3

and more than 1.5 times the interquartile range outside the quartile

\begin{tabular}{|l}
$\begin{array}{l}\text { Data value less than or equal to } 1.5 \text { times } \\
\text { the interquartile range outside the quartile } \\
\text { 75th percentile } \\
\text { Upper notch } \\
\text { Median } \\
\text { Lower notch } \\
\text { 25th percentile }\end{array}$ \\
\hline
\end{tabular}

Figure 3-3. Boxplots showing the composition of 75 groundwater samples from Lycoming County, Pennsylvania, 2014, classified as anoxic $(n=14)$, mixed $(n=10)$, and oxic $(n=51)$ on the basis of dissolved oxygen concentration and other water-quality criteria of McMahon and Chapelle (2008). (n, number of samples; =, equal to) 


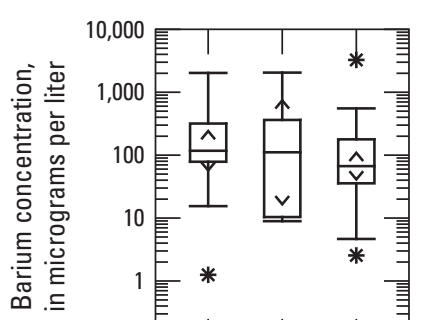

$$
0.1 \text { E }
$$

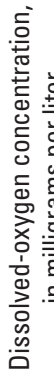
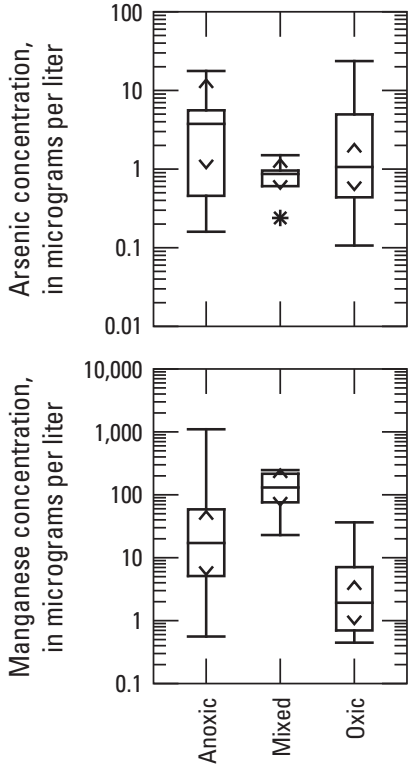

Redox classification
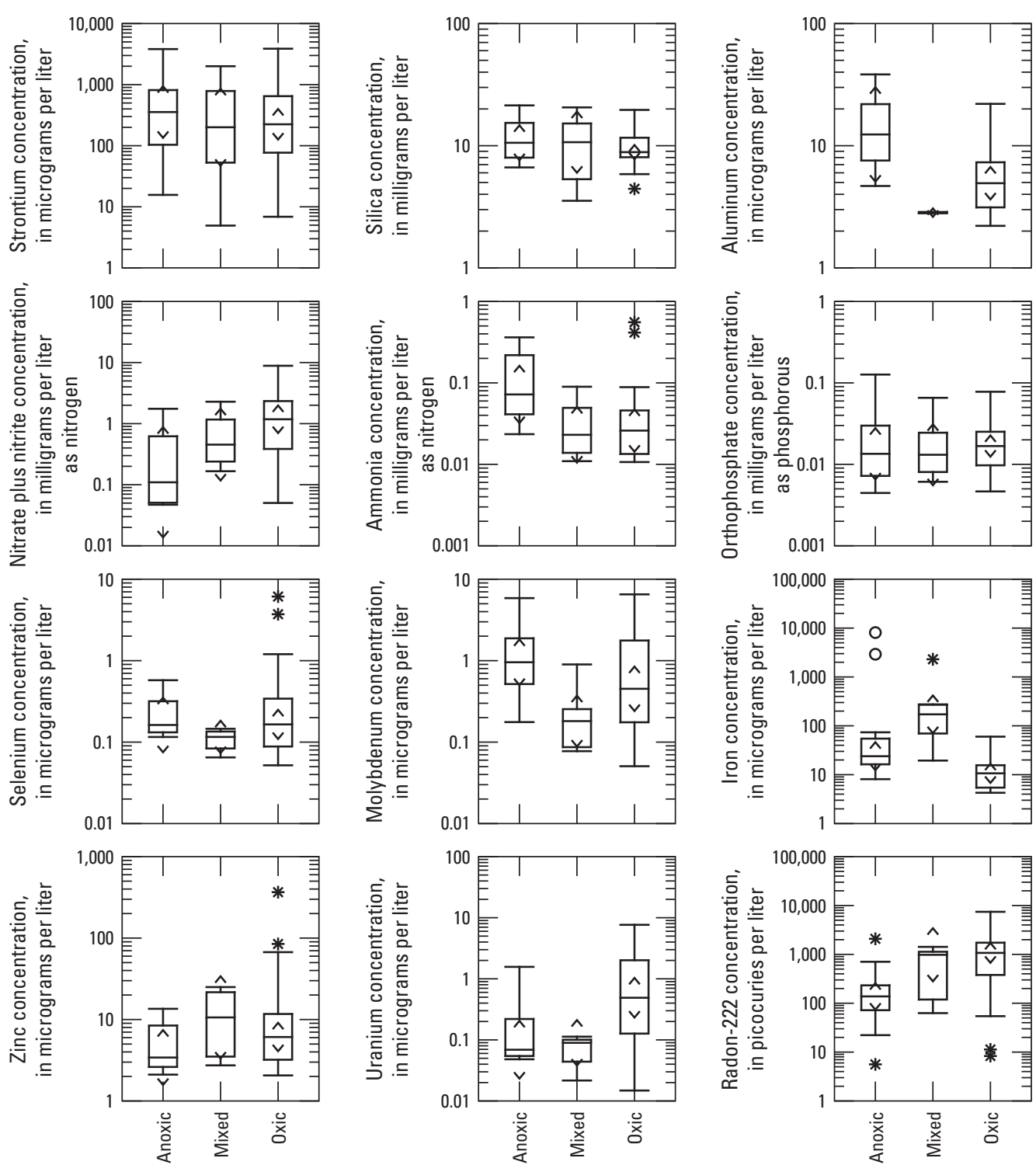

Redox classification

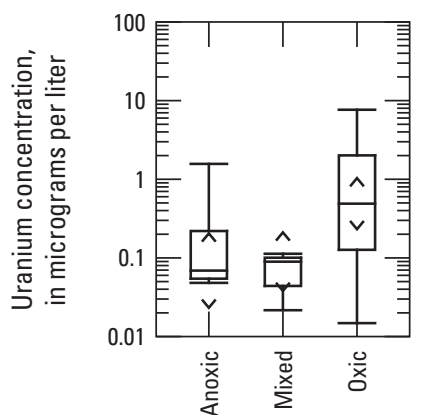

Redox classification
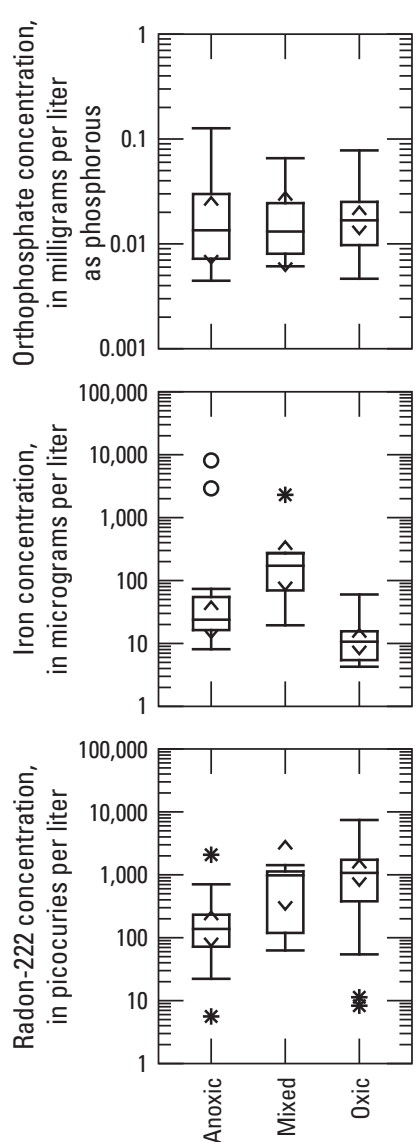

Redox classification

\section{EXPLANATION}

O Outlier data value more than 3 times the interquartile range outside the quartile

* Outlier data value less than or equal to 3

and more than 1.5 times the interquartile range outside the quartile

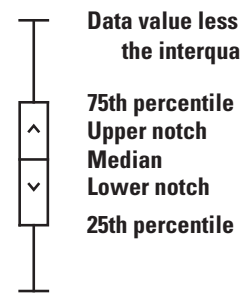

Figure 3-3. Boxplots showing the composition of 75 groundwater samples from Lycoming County, Pennsylvania, 2014, classified as anoxic $(n=14)$, mixed $(n=10)$, and oxic $(n=51)$ on the basis of dissolved oxygen concentration and other water-quality criteria of McMahon and Chapelle (2008). (n, number of samples; =, equal to)—Continued 


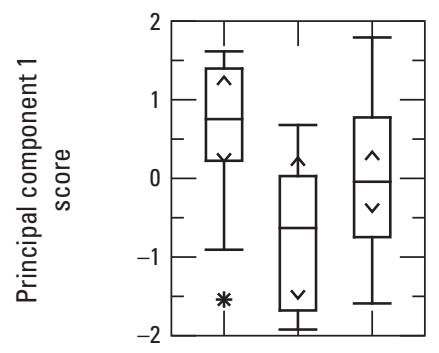



Redox classification

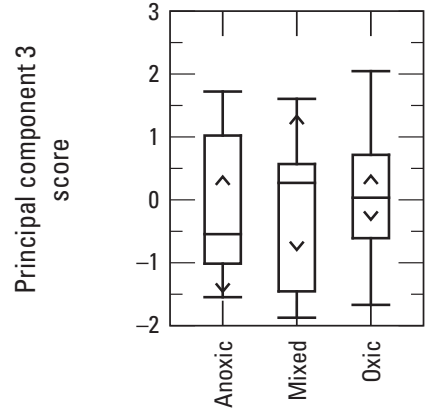

Redox classification

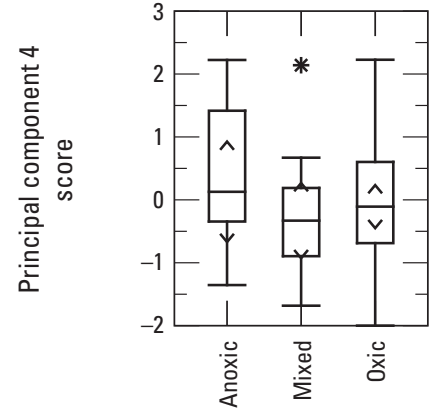

Redox classification

\section{EXPLANATION}

O Outlier data value more than 3 times the interquartile range outside the quartile

* Outlier data value less than or equal to 3 and more than 1.5 times the interquartile range outside the quartile

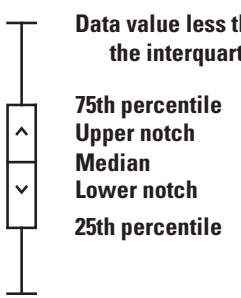

Figure 3-3. Boxplots showing the composition of 75 groundwater samples from Lycoming County, Pennsylvania, 2014, classified as anoxic $(n=14)$, mixed $(n=10)$, and oxic $(n=51)$ on the basis of dissolved oxygen concentration and other water-quality criteria of McMahon and Chapelle (2008). (n, number of samples; =, equal to)_Continued 

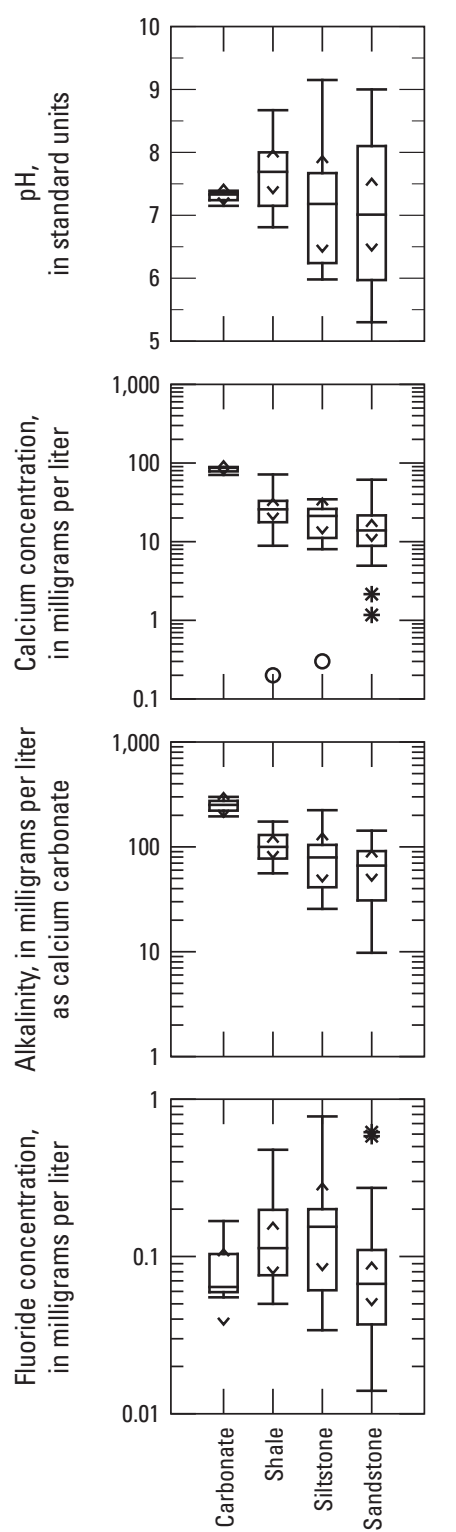

Lithologic classification
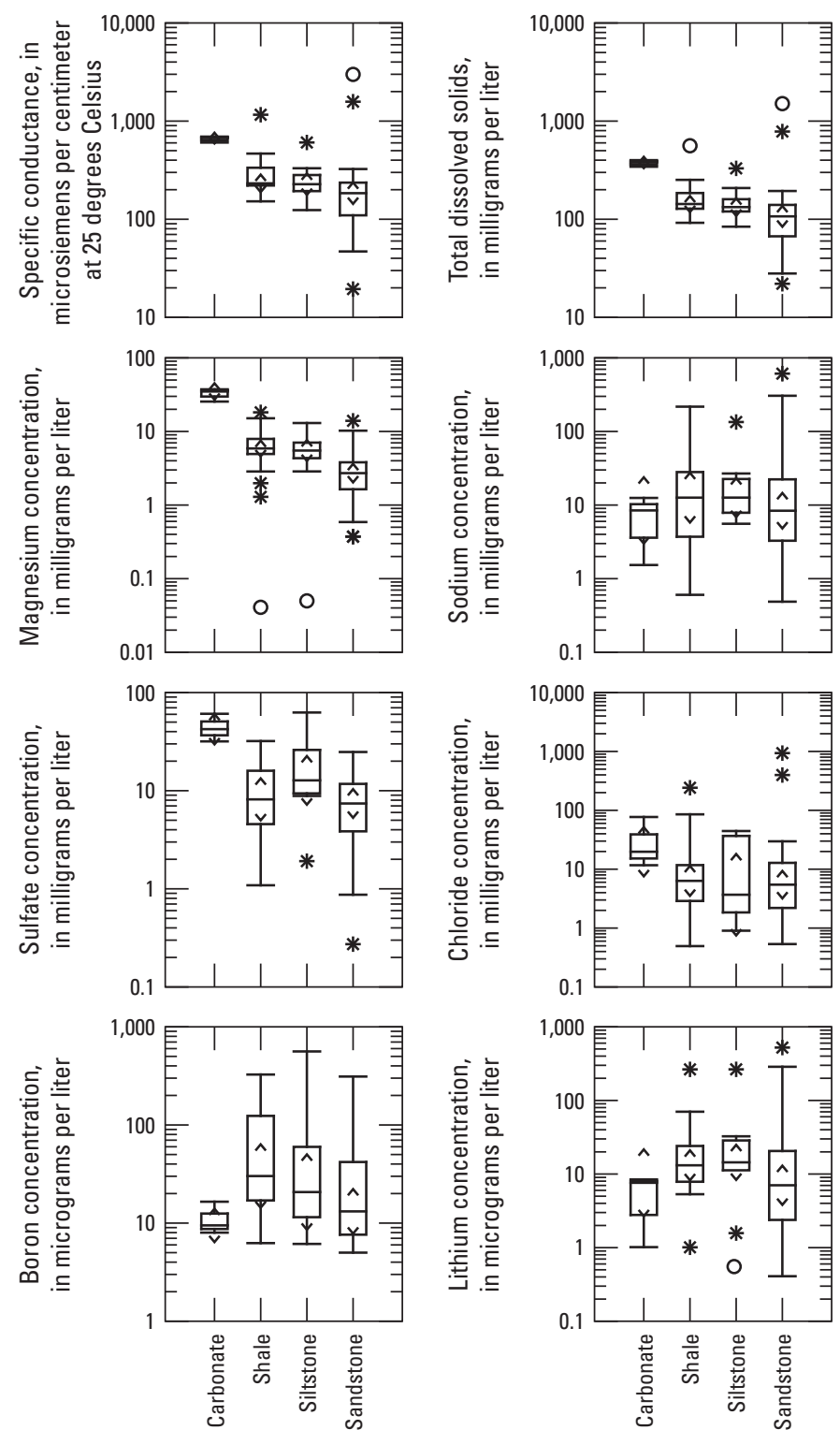

Lithologic

classification

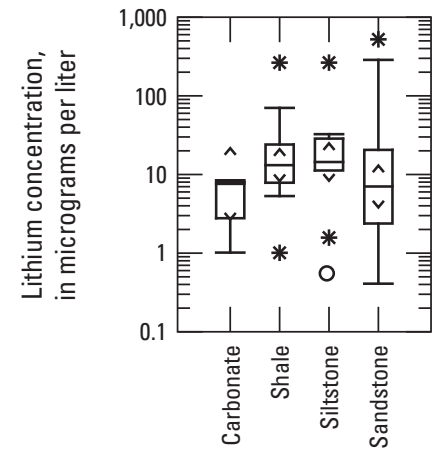

Lithologic

classification
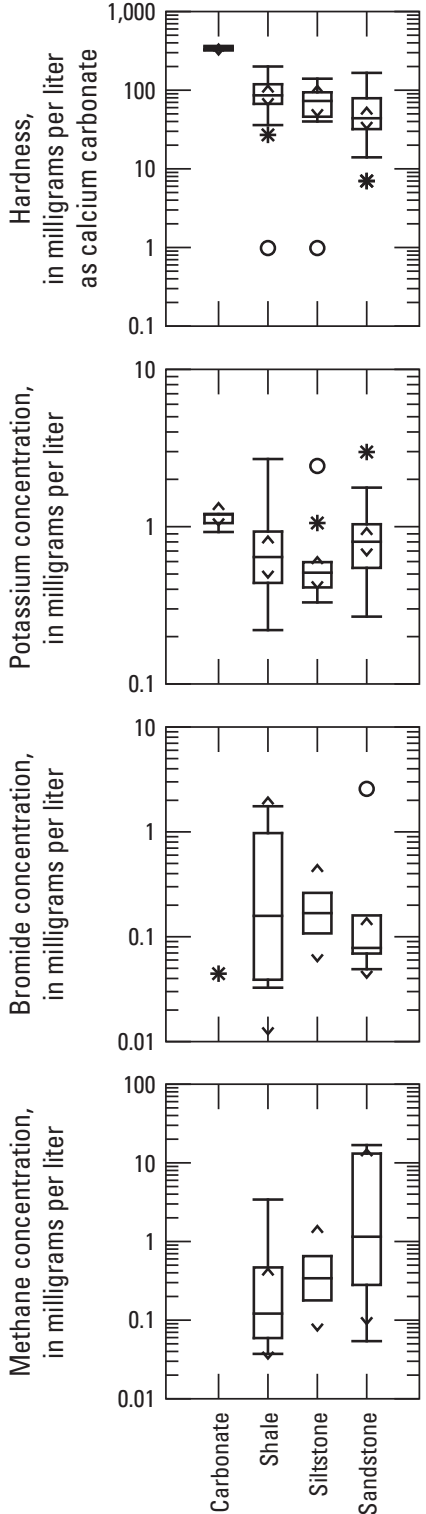

Lithologic classification

\section{EXPLANATION}

O Outlier data value more than 3 times the interquartile range outside the quartile

* Outlier data value less than or equal to 3

and more than 1.5 times the interquartile range outside the quartile

\begin{tabular}{l} 
Data value less than or equal to 1.5 times \\
the interquartile range outside the quartile \\
$\begin{array}{l}75 \text { th percentile } \\
\text { Upper notch } \\
\text { Median } \\
\text { Lower notch } \\
25 \text { th percentile }\end{array}$ \\
\hline
\end{tabular}

Figure 3-4. Boxplots showing the composition of 75 groundwater samples from Lycoming County, Pennsylvania, 2014, classified as carbonate $(n=3)$, shale $(n=21)$, siltstone $(n=10)$, and sandstone $(n=41)$ on the basis of lithologic class identified by Pennsylvania Bureau of Topographic and Geologic Survey (2001) and Taylor and others (1983). (n, number of samples; =, equal to) 



Lithologic
classification

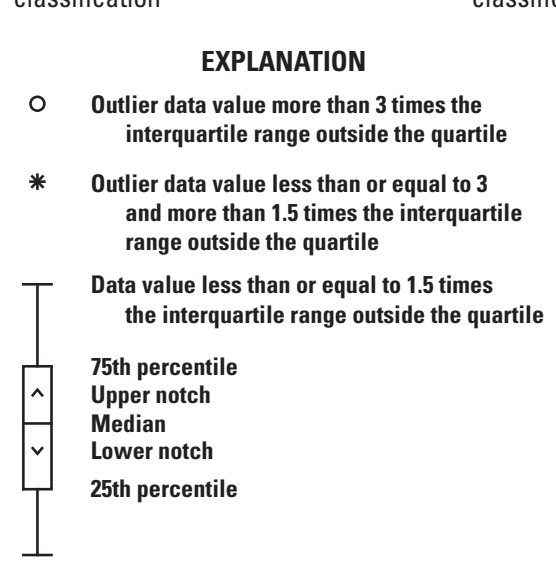

Figure 3-4. Boxplots showing the composition of 75 groundwater samples from Lycoming County, Pennsylvania, 2014, classified as carbonate $(n=3)$, shale $(n=21)$, siltstone $(n=10)$, and sandstone $(n=41)$ on the basis of lithologic class identified by Pennsylvania Bureau of Topographic and Geologic Survey (2001) and Taylor and others (1983). (n, number of samples; =, equal to)—Continued 


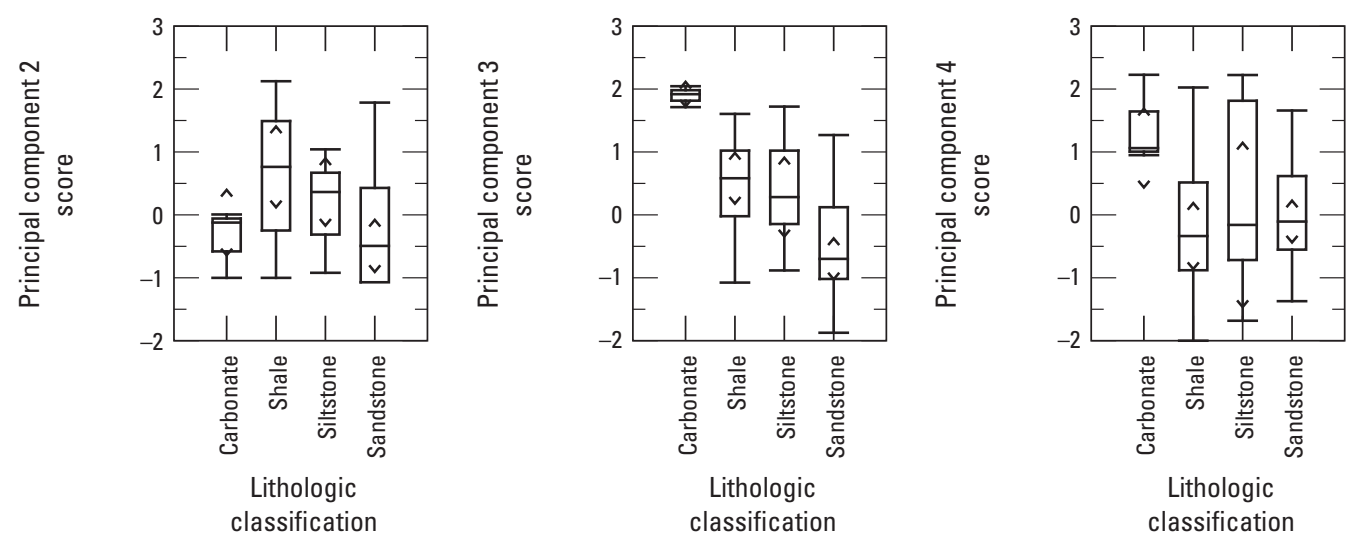

\section{EXPLANATION}

O Outlier data value more than 3 times the interquartile range outside the quartile

* Outlier data value less than or equal to 3

and more than 1.5 times the interquartile range outside the quartile

\begin{tabular}{|ll}
\multicolumn{1}{|c|}{$\begin{array}{l}\text { Data value less } \\
\text { the interquar }\end{array}$} \\
75th percentile \\
Upper notch \\
Median \\
Lower notch \\
25th percentile
\end{tabular}

Figure 3-4. Boxplots showing the composition of 75 groundwater samples from Lycoming County, Pennsylvania, 2014, classified as carbonate $(n=3)$, shale $(n=21)$, siltstone $(n=10)$, and sandstone $(n=41)$ on the basis of lithologic class identified by Pennsylvania Bureau of Topographic and Geologic Survey (2001) and Taylor and others (1983). (n, number of samples; =, equal to)—Continued 
Publishing support provided by the U.S. Geological Survey Science Publishing Network, West Trenton Publishing Service Center

For more information concerning the research in this report, contact: Director, Pennsylvania Water Science Center

U.S. Geological Survey

215 Limekiln Road

New Cumberland, Pa. 17070

http://pa.water.usgs.gov/ 


\section{$\frac{\mathbb{3}}{3}$}

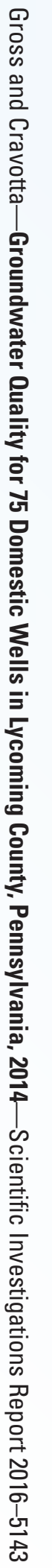

